Western University

Scholarship@Western

Earth Sciences Publications

Earth Sciences Department

2018

\title{
Petrogenetic and Geodynamic Origin of the Neoarchean Doré Lake Complex, Abitibi Subprovince, Superior Province, Canada
}

Ali Polat

University of Windsor

Robert Frei

University of Copenhagen

Fred J. Longstaffe

The University of Western Ontario, flongsta@uwo.ca

Ryan Woods

University of Windsor

Follow this and additional works at: https://ir.lib.uwo.ca/earthpub

Part of the Geochemistry Commons, Geology Commons, and the Tectonics and Structure Commons

Citation of this paper:

Polat, Ali; Frei, Robert; Longstaffe, Fred J.; and Woods, Ryan, "Petrogenetic and Geodynamic Origin of the Neoarchean Doré Lake Complex, Abitibi Subprovince, Superior Province, Canada" (2018). Earth Sciences Publications. 27.

https://ir.lib.uwo.ca/earthpub/27 
3

29 Submitted to International Journal of Earth Sciences 30

$31 *$ Corresponding author (polat@uwindsor.ca)

9

(1)

(1)

4

5

7

0

\section{Petrogenetic and geodynamic origin of the Neoarchean Doré Lake Complex, Abitibi subprovince, Superior Province, Canada}

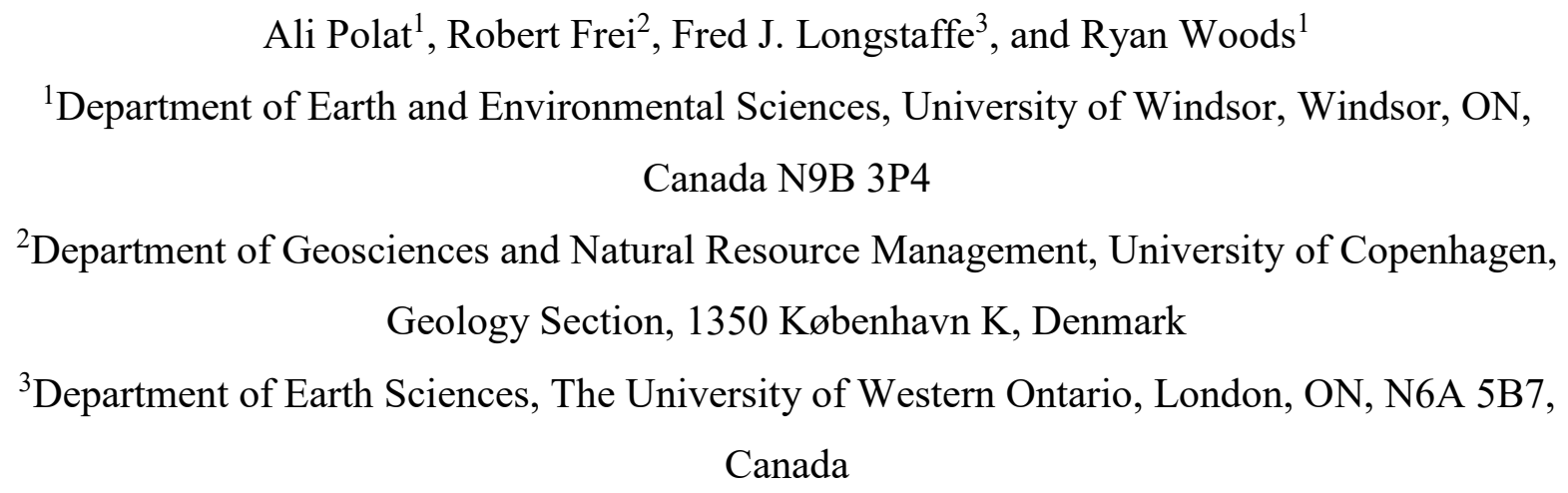




\section{Abstract}

The Neoarchean (ca. $2728 \mathrm{Ma}$ ) anorthosite-bearing Doré Lake Complex in the northeastern Abitibi subprovince, Quebec, was emplaced into an association of intra-oceanic tholeiitic basalts and gabbros known as the Obatogamau Formation. The Obatogamau Formation constitutes the lower part of the Roy Group, which is composed of two cycles of tholeiitic to calc-alkaline volcanic and volcaniclastic rocks, siliciclastic and chemical sedimentary rocks, and layered mafic to ultramafic sills. In this study, we report major and trace element results, and $\mathrm{Nd}, \mathrm{Sr}, \mathrm{Pb}$ and $\mathrm{O}$ isotope data for anorthosites, leucogabbros, gabbros and mafic dykes from the Doré Lake Complex and spatially associated basalts and gabbros of the Obatogamau Formation to assess their petrogenetic origin and geodynamic setting.

Field and petrographic observations indicate that the Doré Lake Complex and associated volcanic rocks underwent extensive metamorphic alteration under greenschist facies conditions, resulting in widespread epidotization (20-40\%) and chloritization (10-40\%) of many rock types. Plagioclase recrystallized mainly to anorthite and albite endmembers, erasing intermediate compositions. Metamorphic alteration also led to the mobilization of many elements (e.g., LILE and transition metals) and to significant disturbance of the $\mathrm{Rb}-\mathrm{Sr}$ and $\mathrm{U}-\mathrm{Pb}$ isotope systems, resulting in $1935 \pm 150 \mathrm{Ma}$ and $3326 \pm 270 \mathrm{Ma}$ errorchron ages, respectively. The Sm-Nd isotope system was less disturbed, yielding an errorchron age of $2624 \pm 160 \mathrm{Ma}$.

On many binary major and trace element diagrams, the least altered anorthosites and leucogabbros, and the gabbros and mafic dykes of the Doré Lake Complex plot in separate fields, signifying the presence of two distinct magma types in the complex. The gabbros and mafic dykes in the Doré Lake Complex share the geochemical characteristics of tholeiitic basalts and gabbros in the Obatogamau Formation, suggesting a possible genetic link between the two rock associations. Initial $\varepsilon \mathrm{Nd}(+2.6$ to +5.0$)$ and $\delta^{18} \mathrm{O}(+6.1$ to $+7.9 \%)$ values for the Doré Lake Complex and gabbros of the Obatogamau Formation $\left(\varepsilon \mathrm{Nd}=+2.8\right.$ to $+4.0 ; \delta^{18} \mathrm{O}=+7.3$ to $8.0 \%$ ) are consistent with depleted mantle sources. All rock types in the Doré Lake Complex and the Roy Group share the trace element characteristics of modern arc magmas, suggesting a suprasubduction zone setting for these two lithological associations. On the basis of regional geology and geochemical data, we suggest that the Doré Lake Complex and the Obatogamau Formation represent a dismembered fragment of a suture zone, like many Phanerozoic ophiolites, resulting from closure of a backarc basin between 2703-2690 Ma. 
Keywords: Doré Lake Complex; Abitibi subprovince, Archean, anorthosite, leucogabbro

\section{Introduction}

Despite their small volumes, anorthosite-bearing layered intrusions are abundant in Archean cratons, particularly in western Greenland and the Superior Province of the Canadian Shield (Windley and Garde 2009; Ashwal 2010; Hoffmann et al. 2012; Percival et al. 2012; Polat et al. 2015). Examples of well-preserved anorthosite-bearing layered intrusions in the Superior Province include the Doré Lake, Bell River, Mulcahy Lake, Shawmere, Bird River, Pipestone, Bad Vermilion Lake and Nelson River complexes (Bell 1978; Simmons and Hanson 1980; Corkery 1985; Ashwal et al. 1983; Ashwal, 1993; Morrison et al., 1985; Edgar and Sweeny 1991; Chown et al. 1992; Mortensen 1993; Maier et al. 1996; Peck et al. 1998, 1999; Hartlaub et al. 2004; Gilbert 2007; Bédard et al. 2009; Yang et al. 2012; Yang and Gilbert 2014; Zhou et al. 2016). In addition, anorthosites occur in Proterozoic orogenic belts, Phanerozoic ophiolites and modern oceanic crust (Ashwal 1993, 2010). Archean anorthosite-bearing layered intrusions are typically associated with tholeiitic to calc-alkaline volcanic rocks of greenstone belts, and were intruded mainly by syn- to post-tectonic tonalite-trondhjemite-granodiorite suites (TTGs) (Ashwal et al. 1983; Myers 1976, 1985; Davis et al. 1988; Daigneault et al. 1990; Leclerc et al. 2011; Polat et al. 2015). Given their temporal restriction to the Archean, spatial association with greenstone belts and syntectonic TTGs, and unique lithological characteristics, studies of anorthosite-bearing layered intrusions can provide significant new insights into petrogenetic, geodynamic and crustal growth processes that operated in the Archean. Despite their abundance and unique lithological characteristics, however, anorthosite-bearing layered intrusions are among the least-studied rock associations in Archean cratons. Thus their mantle source characteristics, petrogenetic evolution, geodynamic setting, and petrogenetic relationships with the spatially associated greenstone belts and TTGs are poorly understood. Similarly, the petrological and tectonic implications of these intrusions for Archean crustal growth processes have not been investigated in detail.

The following outstanding petrogenetic and geodynamic questions need to be addressed to better understand the origin of these intrusions: (1) What are the mantle source characteristics of Archean anorthosite-bearing layered intrusions? (2) Are these layered intrusions genetically related to the spatially associated volcanic rocks of greenstone belts? (3) Did Archean 
anorthosite-bearing layered intrusions intrude oceanic or continental crust? (4) What is the geodynamic setting(s) of these intrusions? (5) What is the geodynamic significance of these layered rocks for Archean geology? These questions can be best addressed by using a multidisciplinary approach and modern analytical methods on well-exposed intrusions and the spatially-associated greenstone belts and TTGs. The Chibougamau area in the Abitibi subprovince of the Superior Province (Fig. 1) is an ideal place to address these questions because it contains diverse volcanic rocks (basalt to rhyolite), an anorthosite-bearing layered intrusion (Doré Lake Complex) and syn- to post-tectonic TTGs (Daigneault et al. 1990; Chown et al. 1992; Mortensen 1993; Bédard et al. 2009; Leclerc et al. 2011). In particular, Bédard et al. (2009) reported major and trace element data for six anorthosite-leucogabbro samples and used the equilibrium distribution and trapped melt fraction methods to determine the composition of 106 the melts that crystallized to form the Neoarchean (ca. $2728 \mathrm{Ma}$ ) Doré Lake Complex.

The present study differs from previous investigations in that it presents extensive new field, petrographic, and whole-rock major and trace element (34 samples) geochemistry, plus $\mathrm{Sm}-\mathrm{Nd}$, U-Th-Pb and Rb-Sr isotope (19 samples), and whole-rock (10 samples) and plagioclase (13 samples) $\mathrm{O}$ isotope data for the Doré Lake Complex to address the petrogenetic and geodynamic questions listed above. In addition, we present new whole-rock major and trace element data for basalts and gabbros (23 samples) from the Obatogamau Formation in the Roy Group (Figs. 2 and 3) to assess the possible petrogenetic relationship between the Doré Lake Complex and the spatially associated greenstone belt. Three gabbro samples from the Obatogamau Formation were also analysed for $\mathrm{Nd}, \mathrm{Pb}, \mathrm{Sr}$ and $\mathrm{O}$ isotopes to compare the mantle source characteristics of the Doré Lake Complex and the Obatogamau Formation. On the basis of new and published data, we revisit the Archean anorthosite petrogenesis and geodynamic models proposed for the Abitibi subprovince.

\section{Regional geology}

\section{Superior Province}

The Superior Province is the largest and one of the most studied Archean cratons in the world (Fig. 1; Card and Ciesielski 1986; Card 1990; Williams et al. 1991; Percival et al. 2012). A widely accepted tectonic model for the Superior Province is one of subduction-accretion growth, involving the accretion of numerous microplates, oceanic island arcs, back-arcs, oceanic 
125

126

127

128

129

130

131

132

133

134

135

136

plateaus and turbidite deposits (Langford and Morin 1976; Devaney and Williams 1989; Card 1990; Williams 1990; Stott 1997; Williams et al. 1991; Sutcliffe et al. 1993; Calvert and Ludden 1999; Percival et al. 2012; Backeberg et al. 2014; Frieman et al. 2017). Recognition of largescale thrust and strike-slip faults in the Abitibi, Pontiac, Wawa, Wabigoon, Opatica and Quetico subprovinces is consistent with a subduction-driven growth model (Poulsen et al. 1980; Dimroth et al. 1983; Davis et al. 1988; Sleep 1992; Benn et al. 1992; Chown et al. 1992; Camiré and Burg 1992; Kimura et al. 1993; Sawyer and Benn 1993; Mueller et al. 1996; Stott 1997; Calvert and Ludden 1999; Percival et al. 2006, 2012; Backeberg et al. 2014). Tectonic accretion models proposed for the Abitibi subprovince in particular and the Superior Province in general, however, have been challenged recently by several studies (Thurston et al. 2002; Bédard 2006; Bédard et al. 2013; Bédard and Harris 2014). Evidence cited in the literature in support of subductionaccretion models, nonetheless, continues to be overwhelming (Percival et al. 2012; Frieman et al. 2017). That the details of the geodynamic processes that generated the Superior Province are currently not fully understood is underscored by this controversy.

Numerous integrated field and geochemical studies in the Superior Province have recognized two major volcanic associations: (1) a tholeiitic to calc-alkaline basalt to rhyolite association sharing the trace element compositions of modern subduction-zone volcanic rocks; and (2) a tholeiitic basalt to komatiite association whose origin is attributed to the partial melting of mantle plumes (Ludden et al. 1986; Dostal and Mueller 1996; Dostal and Mueller 1997; Polat and Kerrich 2001; Polat et al. 1998; Wyman 1999; Hollings and Wyman 1999; Hollings et al. 2000; Sproule et al. 2002; Leclerc et al. 2011; Lodge et al. 2015). In addition, there are minor boninite, high-Mg andesite, $\mathrm{Nb}$-enriched basalt, low-Ti tholeiite and adakite occurrences within the tholeiitic to calc-alkaline volcanic association (Polat and Kerrich 2006).

\section{Abitibi subprovince}

The Abitibi subprovince is one of the most extensively studied Archean plutonic-volcanic terrains in the Superior Province (see Dimroth et al. 1982; Jackson and Fyon 1991; Ayer et al. 2002; Chown et al. 2002; Daigneault et al. 2002; Leclerc et al. 2011; Moyen and van Hunen 2012; Wyman 2013). Ludden and Hubert (1986) divided the Abitibi subprovince into three major parts including the Northern Volcanic Zone, Central Granite-Gneiss Zone, and Southern Volcanic Zone. On the basis of rock associations, history of deformation and $\mathrm{U}-\mathrm{Pb}$ zircon ages, 
later studies have delineated the Northern and Southern Volcanic Zones only (see Chown et al 1992; Jackson and Cruden 1995; Goodwin 1996; Mueller et al. 1996; Calvert and Ludden 1999; Daigneault et al. 2002, 2004). This subdivision, however, still remains controversial (see Ayer et al. 2002). Both the Southern and Northern Volcanic Zones are dominated synvolcanic to postvolcanic TTG plutons, komatiites, pillow basalts, basaltic to rhyolitic bimodal volcanic associations, and east-west trending sedimentary sequences. Komatiites are abundant in the Southern Volcanic Zone, whereas anorthosite-bearing layered intrusions, such as the Doré Lake Complex near Chibougamau and the Bell River Complex near Matagami, are abundant in the Northern Volcanic Zone.

Periods of volcanic eruption in the Abitibi subprovince are broadly divided into three cycles: (1) 2730-2725 Ma; (2) 2720-2714 Ma; and (3) 2705-2700 Ma (Chown et al. 2002). Some volcanic rocks appear to have erupted as early as $2750 \mathrm{Ma}$ (Ayer et al. 2002). Eruption of volcanic rocks in all three cycles is attributed to subduction-related tectonic processes that were accompanied by synvolcanic granitoid emplacement (Chown et al. 2002). Studies in the Southern Volcanic Zone indicate that the subduction-related volcanism was coeval with mantle plume-related volcanism (Dostal and Mueller 1997; Ayer et al. 2002; Wyman et al. 2002). The main compressional deformation took place between 2703 and $2692 \mathrm{Ma}$, which was followed by strike-slip faulting between 2690-2670 Ma and crustal extension at about $2660 \mathrm{Ma}$ (Chown et al. 2002). Sedimentary rocks are generally younger than the igneous rocks, having a maximum depositional age of $2698 \mathrm{Ma}$ (Davis 1992; Bleeker and Parrish 1996).

Like many other Archean terrains, the Northern Volcanic Zone is characterized by heterogeneous deformation consisting of alternating linear high-strain and low-strain domains. Chown et al. (1992) documented six phases of deformation in the Northern Volcanic Zone that occurred over a period of $25 \mathrm{Ma}$ and resulted from north-south shortening in response to a single major orogenic event. North-south shortening was first recorded by near-vertical east-west trending folds and thrust faults. These events were followed by east- and southeast-trending right-lateral strike-slip faults. The faults controlled the emplacement of syntectonic TTG plutons between 2703-2690 Ma (Chown et al. 1992, 2002). Contact between the Northern Volcanic Zone and the plutonic Opatica belt is marked by $4-5 \mathrm{~km}$ wide zone of mylonitic rocks with shear-sense indicators suggesting south-over-north tectonic movement (Chown et al. 1992, 2002). 
Geochronological studies suggest that magmatism in the entire Abitibi subprovince was broadly contemporaneous from south to the north (see Corfu 1993; Davis et al. 2000; Ayer et al. 2002). Plutonic rocks in the Abitibi subprovince are divided into three groups, including 27402698 Ma synvolcanic, 2705-2680 Ma syntectonic and 2665-2640 Ma post-tectonic (see Corfu 1993; Davis et al. 2000; Ayer et al. 2002). These plutonic rocks are predominantly juvenile in nature and do not contain large amounts of older recycled crust (Vervoort et al. 1994; Bédard and Ludden 1997; Ayer et al. 2002). Chown et al (2002) showed that the origin of the granitoid rocks is closely related to tectonic processes and that they have subduction zone geochemical characteristics.

On the basis of structural and Lithoprobe seismic reflection data, Lacroix and Sawyer (1995) demonstrated that the northwestern segment of the Abitibi subprovince represents a crustal-scale fold and thrust belt, resulting from a south to southwest-verging tectonic movement in response to north-south crustal thickening. Calvert and Ludden (1999) showed that the southern and northern boundaries of the Abitibi subprovince are marked by suture zones separating the subprovince from the Pontiac metasedimentary and the Opatica plutonic subprovinces, respectively (Fig. 1). These suture zones are characterized mainly by sedimentarydominated tectonic wedges.

Daigneault et al. (2002) presented a detailed tectonic evolution model for the Abitibi subprovince using field relationships, and structural and geochronological data. They concluded that the subprovince was deformed mainly by compressional and right-lateral transpressional deformation resulting from oblique plate convergence. The geological characteristics of the Northern Volcanic Zone are consistent with a dextral transpressional tectonic regime. The subprovince was generated by accretion of the Northern Volcanic Zone, Southern Volcanic Zone and Pontiac subprovince during oblique convergence involving two contemporaneous subduction zones beneath the Northern and Southern Volcanic Zones (i.e., the Blake River and eastern Malartic segments). The Northern and Southern Volcanic Zones are linked by the crustalscale right-lateral Destor-Porcupine-Manneville strike-slip fault zone in which deformation appears to have migrated from north to south. The Cadillac-Larder Lake Fault Zone separates the Abitibi and Pontiac subprovinces. The Northern Volcanic Zone is interpreted to be a separate arc in the northern part of the subprovince (Daigneault et al. 2002). 
Ayer et al. (2002) provided a review of geochronological, magmatic, sedimentological,

217 structural and geochemical processes recorded in the Southern Volcanic Zone. On the basis of U$218 \mathrm{~Pb}$ zircon geochronology and mapping, Ayer et al. (2002) suggested that the southern Abitibi 219 subprovince contains nine autochthonous supracrustal assemblages, including variable

220

221

222

223

224

225

226

227

228

229

230

231

232

233

234

235

236

237

238

239

240

241

242

243

244

245 proportions of komatiite, tholeiitic basalt, calc-alkaline basalt to rhyolite and minor sedimentary rocks. Most assemblages include both tholeiitic and calc-alkaline volcanic rocks. The autochthonous deposition of volcanic and sedimentary rocks in the southern part of the Abitibi subprovince over 50 million years is attributed to a long-lived plume-subduction interaction (Ayer et al. 2002).

\section{Chibougamau area}

The Chibougamau area is located in the northeastern section of the Northern Volcanic Zone of the Abitibi subprovince (Figs. 1 and 2; Dimroth et al. 1984; Mueller et al. 1989; Daigneault et al. 1990; Mueller 1991; Chown et al. 1992; Bédard et al. 2009; Leclerc et al. 2011). It is bordered by the Grenville Province to the east and southeast, and by the Opatica subprovince to the north. The metamorphism in the area ranges from greenschist to amphibolite facies. The highest metamorphic grade occurs in contact metamorphic aureoles developed at the borders of the synvolcanic plutons.

On the basis of detailed field mapping, Daigneault et al. (1990) recognized at least three phases of Archean and one phase of Grenvellian deformation in the area. Deformation phase 1 $\left(D_{1}\right)$ is characterized by north-south folds without well-developed axial plane foliation. East-west $\mathrm{D}_{2}$ folds are the most prominent structures in the area that include the Waconichi, Chibougamau and Chapais synclines and the Chibougamau anticline (Daigneault et al. 1990). Plutons were emplaced in the cores of major anticlines. $\mathrm{D}_{2}$ also includes reverse faults, mesoscopic isoclinal folds and axial planar schistosity produced by a north-south shortening deformation event (Daigneault et al. 1990). $\mathrm{D}_{3}$ deformation is represented by small-scale folds, kink bands and crenulation cleavage, which are interpreted to have been formed towards the end of regional deformation. East-west-trending synclinal basins are filled with younger sediments and bordered by the east-west striking $\mathrm{D}_{2}$ reverse faults. Grenvillian deformation (1110-970 Ma) is mainly restricted to the eastern part of the area. 
Lithologically, the Chibougamau area consists mainly of synvolcanic and syntectonic TTG plutons, basaltic to rhyolitic bimodal cyclic volcanic rocks, siliciclastic sedimentary rocks, layered mafic to ultramafic sills, and an anorthosite-bearing layered intrusion termed the Doré Lake Complex (Allard et al. 1979, 1985; Mueller et al. 1989; Daigneault et al. 1990, 1992; Leclerc et al. 2011; Bédard 2009) (Figs. 2 and 3). Daigneault et al. (1990) suggested that the supracrustal rocks, including the pillow basalts and minor felsic pyroclastic rocks, formed during an extensional tectonic regime.

The Doré Lake Complex consists mainly of anorthosites, leucogabbros and gabbros, and it has a preserved thickness of between 5 and 7 km (Figs. 4 and 5) (Allard 1976; Daigneault et al. 1990). The complex is subdivided into five zones including the anorthosite, gabbro-magnetite, ferrodiorite, soda-granophyre, and gabbroic to pyroxenitic zones (Daigneault et al. 1990). Cumulate textures and megacrystic plagioclase are well preserved in the anorthosites and leucogabbros (Figs. 4 and 5). The gabbros, however, rarely exhibit a cumulus texture. Both the anorthosites and leucogabbros are intruded by mafic dykes and pods of gabbro (Figs. 5e, f and 6a). The leucogabbros grade into the anorthosite by increasing the plagioclase content (Figs. 4 and 5). The ages of the mafic dykes and gabbroic pods are currently unknown. The complex also contains vanadium- and titanium-bearing magnetite layers (Taner et al. 1998). The Doré Lake Complex was emplaced into the basaltic to gabbroic rocks of the Obatogamau Formation in the Roy Group at about $2728 \mathrm{Ma}$, and it is coeval with the felsic volcanic rocks of the Waconichi Formation (Mortensen 1993; Bédard et al. 2009; Leclerc et al. 2011).

Supracrustal rocks in the Chibougamau area, including bimodal basalt to rhyolite volcanic rocks, pyroclastic rocks, banded iron formations and siliciclastic sedimentary rocks, are collectively known as the Roy Group (Allard et al. 1979, 1985; Ludden et al. 1986; Mueller et al. 1989; Daigneault et al. 1990, 1992; Leclerc et al. 2011; Bédard et al. 2009). The Roy Group is intruded by the 2728 Ma Doré Lake Complex, the 2718-2714 Ma synvolcanic TTG-dominated Chibougamau pluton, and the 2717 Ma mafic to ultramafic sills of the Cumming Complex (Figs. 2 and 3; Krogh 1982; Daigneault et al. 1990; Chown et al. 1992; Mortensen 1993; Bédard et al. 2009; Leclerc et al. 2011).

Field, geochronological and geochemical studies indicate that the supracrustal rocks in the Roy Group formed during two volcanic cycles (Ludden et al. 1984; Daigneault et al. 1990; Leclerc et al. 2011, and references therein). Each cycle consists of several kilometers of thick 
277 tholeiitic basalts on the bottom with thin felsic volcanic and volcaniclastic rocks interlayered 278 with banded iron formation and chert on the top. Based on new mapping and geochronological 279 and geochemical studies, Leclerc (2011) revised the previous stratigraphy of the Roy Group to 280 the north of the Doré Lake Complex (Fig. 2 and 3) and suggested that the term "Gilman 281 Formation" should no longer be used in the stratigraphic nomenclature of the Chibougamau area. 282 In the revised stratigraphy, the lower part of the Gilman Formation was redefined as the David 283 Member and reassigned to the Obatogamau Formation, the upper part redefined as the Allard 284 Member and reassigned to the Waconichi Formation, and the uppermost part renamed as the 285 Bruneau Formation as a new formation. The Obatogamau and Blondeau Formations were 286 preserved in the new stratigraphic nomenclature, but the Upper Member of the Obatogamau 287 Formation was reassigned to the David Member (Fig. 3). The Roy Group is unconformably 288 overlain by the Opémisca Group, which consist mainly of siliciclastic sedimentary rocks 289 (Daigneault et al. 1990; Dimroth et al. 1983; Mueller 1991; Mueller and Corcoran 1998; Leclerc et al. 2011). The uplifting and unroofing of the Roy Group, Doré Lake Complex and synvolcanic plutons provided sediments for the Opémisca Group (Dimroth et al. 1986; Daigneault et al. 1990; Mueller 1991; Chown et al. 1992; Mueller and Corcoran 1998).

The Obatogamau and Waconichi Formations constitute cycle 1 of the Roy Group. The Obatogamau Formation is composed of voluminous, 3-4 km thick, basalts with massive to pillowed structures and gabbroic sills (Fig. 3 and 6). The Waconichi Formation is composed mainly of up to 800 meters of felsic lavas and pyroclastic rocks. The felsic volcanic rocks of cycle 1 and the co-genetic dykes were emplaced, on or intruded into the subaqueous basalts between 2730 and 2725 Ma (Chown et al. 1992; Mortensen 1993). This was followed by the extrusion of cycle 2 volcanic rocks between 2722-2712 Ma. The Bruneau and Blondeau 300 Formations include the volcanic rocks of cycle 2 in the Roy Group (Fig. 3). The Bruneau 301 Formation consists of tholeiitic massive to pillowed basalts. The Blondeau Formation is 302 composed of $2-3 \mathrm{~km}$ thick, volcanogenic siliciclastic turbidites, rhyolites, basalts and 303 volcaniclastic rocks that represent a transition to the overlying the Opémisca Group. Sedimentary 304 rocks of cycle 2 appear to have been deposited in a variety of basins that include deep-marine 305 slope, shallow-marine and alluvial fan setting (Mueller and Dimroth 1984; Chown et al. 1992). 306 Gabbroic sills are intruded throughout the Roy Group (Bédard et al. 2009). Mueller et al. (1989) 307 suggested that the volcanic cycles represent the deposition of extensive seafloor basaltic flows, 
followed by the construction of felsic volcanoes, and then uplift and erosion of the volcanic sequences resulting in the deposition of siliciclastic and volcaniclastic sedimentary rocks.

The 2717 Ma Cummings Complex was emplaced as three differentiated sills into the Bruneau and Blondeau Formations of the Roy Group during volcanic cycle 2 (Figs. 3 and 6) (Mortensen 1993; Bédard et al. 2009; Leclerc et al. 2011). On the basis of field and petrographic characteristics, the Cummings Complex is divided into three internally differentiated sills, named the Roberge, Ventures and Bourbeau sills (Fig. 3). These sills are composed mainly of several hundreds of meters in thickness of gabbro, peridotite and pyroxenite with minor dunite, diorite and granophyre (Figs. 3 and 6). Contacts between the Cummings Complex and host rocks of the Roy Group are commonly marked by thrust faults (Fig. 6; see also Fig. 4 in Bédard et al. 2009).

Felsic intrusive rocks were emplaced during two stages at 2722-2714 Ma as syn-volcanic intrusions and at 2703-2690 Ma as syntectonic intrusions (Daigneault et al. 1990; Chown et al. 1992; Mortensen 1993). The emplacement of the synvolcanic plutons such the $2718 \mathrm{Ma}$ Chibougamau pluton between 2722-2714 Ma indicates a major phase of magmatic activity during volcanic cycle 2 . These plutons were intruded into the cores of the $\mathrm{D}_{2}$ anticlines (Fig. 2). Compositionally, the synvolcanic plutons are mainly polyphase tonalites and diorites. The nature of the contacts between different phases of plutons ranges from sharp to gradual. The borders of the synvolcanic plutons are marked by 1 to $3 \mathrm{~km}$ wide strongly-deformed, commonly mylonitized and transposed, contact aureoles extending well into the neighbouring supracrustal rocks (Daigneault et al. 1990; Chown et al. 1992). The 2703-2690 Ma syntectonic plutons were emplaced during regional deformation. Syntectonic plutons occur at the edges of synvolcanic plutons or between layered intrusions and supracrustal rocks. These plutons are composed mainly of monzodiorite, tonalite and granodiorite that are cut by compositionally similar dykes. Some of the intrusions contain hornblendite and diorite xenoliths at their margins. Post-tectonic plutons occur along the late-tectonic structures and are composed mainly of granodiorite with a less voluminous association of syenite and carbonatite (Chown et al. 1992).

\section{Sampling}

Sampling was conducted in the Neoarchean Doré Lake Complex and the spatially and temporally associated Obatogamau Formation of the Roy Group in the Chibougamau area (Figs. 1-3). Sampling in the Doré Lake Complex included anorthosites, leucogabbros, gabbros and 
mafic dykes, whereas sampling in the Obatogamau Formation was focused on basalts and gabbros (Figs. 2-6). The sample weights ranged from 3 to $6 \mathrm{~kg}$. The Global Positioning System (GPS) coordinates for the sample locations are given in Supplementary Tables 1 and 2.

\section{Analytical methods}

A Scanning Electron Microscope-Energy Dispersive X-ray Spectrometer (SEM-EDS) equipped with a Back Scattered Electron (BSE) imaging unit and a transmitted light microscope were used at the University of Windsor to study the mineralogical composition and texture of the samples.

Samples were also analysed for major and trace elements, and for $\mathrm{Nd}, \mathrm{Pb}, \mathrm{Sr}$ and $\mathrm{O}$ isotopes. Details of major and trace element, $\mathrm{Rb}-\mathrm{Sr}, \mathrm{Sm}-\mathrm{Nd}$ and $\mathrm{U}-\mathrm{Th}-\mathrm{Pb}$ isotope, and $\mathrm{O}$ isotope analyses are given in Polat et al. (2016), Wu et al. (2016), and Polat and Longstaffe (2014), respectively. Therefore, only a short summary of the analytical methods is presented here.

\section{Major and trace elements}

Major elements were analysed by ICP at Activation Laboratories Ltd. (Actlabs) in Ancaster, Ontario, Canada. The values for loss-on-ignition (LOI) were calculated by weight loss upon heating at $1100^{\circ} \mathrm{C}$ for three hours. The samples were fused with a mixture of lithium metaborate and lithium tetraborate, and then dissolved in 5\% nitric acid solution. Totals for major element oxides are $100 \pm 1.5$ wt. $\%$. Reproducibility of analyses is better than $\pm 5 \%$ of the amount present. Detection limits and the results of standard and duplicate analyses are given in Polat et al. (2016).

Trace element analyses were conducted at Geoscience Laboratories (Geo Labs) in Sudbury, Ontario, using ICP-MS following the analytical procedure described in Burnham et al. (2002), Burnham and Schweyer (2004) and Schweyer (2006). The samples were digested by using multiacid techniques (method code IMC-100). Reproducibility of most element analyses is generally better than $\pm 10 \%$ of the amount present (see Polat et al. 2012, 2016).

Anomalous element ratios including $\mathrm{Eu} / \mathrm{Eu}^{*}, \mathrm{Ce} / \mathrm{Ce}^{*}, \mathrm{Nb} / \mathrm{Nb} *, \mathrm{Sr} / \mathrm{Sr} *, \mathrm{~Pb} / \mathrm{Pb}{ }^{*}, \mathrm{Zr} / \mathrm{Zr}$ * and Ti/Ti* were calculated following Taylor and McLennan (1985). Mg-numbers (\%) were calculated as the molecular ratio of $\mathrm{Mg} /\left(\mathrm{Mg}+\mathrm{Fe}^{2+}\right)$, where $\mathrm{Fe}^{2+}$ is assumed to be $90 \%$ of total $\mathrm{Fe}$. 
Trace elements were normalized to N-MORB (Sun and McDonough 1989) for geochemical interpretation.

\section{$\mathrm{Sm}-\mathrm{Nd}, \mathrm{U}-\mathrm{Th}-\mathrm{Pb}$ and $\mathrm{Sr}$ isotope analyses}

Twenty-two samples were analysed for $\mathrm{Sm}-\mathrm{Nd}, \mathrm{U}-\mathrm{Th}-\mathrm{Pb}$ and $\mathrm{Sr}$ isotopes using a VG Sector 54 IT Thermal Ionization Mass Spectrometer (TIMS) at the Geological Institute, University of Copenhagen, Denmark. Samples were mixed with a ${ }^{150} \mathrm{Nd} /{ }^{147} \mathrm{Sm}$ spike before digestion. Samples were dissolved in concentrated $\mathrm{HNO}_{3}, \mathrm{HCl}$ and $\mathrm{HF}$ within Savillex ${ }^{\mathrm{TM}}$ beakers on a hotplate at $130^{\circ} \mathrm{C}$ for three days (see Frei and Polat 2013; Wu et al. 2016 for details).

Chromatographic separation columns charged with 12 ml AG50W-X 8 (100-200 mesh) cation resin were used for $\mathrm{Sr}$ and REE separation. Samarium and $\mathrm{Nd}$ were further separated using smaller chromatographic columns containing Eichrom's ${ }^{\mathrm{TM}}$ LN resin SPS (Part\#LN-B25S). Strontium fractions were purified using a standardized $3 \mathrm{M} \mathrm{HNO}_{3}-\mathrm{H}_{2} \mathrm{O}$ elution recipe on selfmade disposable mini-extraction columns including mesh 50-100 SrSpec ${ }^{\mathrm{TM}}$ (Eichrome Inc.) resin. Separation of $\mathrm{Pb}$ was performed using conventional glass and miniature glass stem anion exchange columns containing $1 \mathrm{ml}$ and $200 \mu \mathrm{l}$ of 100-200 mesh Bio-Rad AG $1 \times 8$ resin, respectively.

Neodymium and Sm isotopes were collected in a multi-dynamic routine and in a static multi-collection mode, respectively, using a triple Ta-Re-Ta filament assembly. Mass bias correction of the measured $\mathrm{Nd}$ isotope ratios was made using the ${ }^{146} \mathrm{Nd} /{ }^{144} \mathrm{Nd}$ ratio of 0.7219 . The JNdi standard measurements yielded a mean value of ${ }^{143} \mathrm{Nd} /{ }^{144} \mathrm{Nd}=0.512093 \pm 12(2 \sigma ; n=5)$ during the period of analyses. Precision for ${ }^{147} \mathrm{Sm} /{ }^{144} \mathrm{Nd}$ ratios is better than $2 \%(2 \sigma)$.

Lead isotopes were measured in a static multi-collection-mode and fractionation was controlled by repeated analysis of the NBS 981 standard (using values of Todt et al. 1993). Total procedural blanks were below $200 \mathrm{pg} \mathrm{Pb}$, which are insignificant with respect to influencing the common lead isotope ratios beyond the significant third digit.

Hundred ng loads of the NBS $987 \mathrm{Sr}$ standard gave ${ }^{87} \mathrm{Sr} /{ }^{86} \mathrm{Sr}=0.710245 \pm 0.000018$ ( $\mathrm{n}=5$, $2 \sigma)$. The ${ }^{87} \mathrm{Sr} /{ }^{86} \mathrm{Sr}$ values of the samples were corrected for the offset relative to the certified NIST SRM 987 value of $0.710250 .{ }^{87} \mathrm{Rb} /{ }^{86} \mathrm{Sr}$ ratios were calculated using ICP-MS Rb and $\mathrm{Sr}$ data. 


\section{Oxygen isotope analyses}

Ten whole-rock samples, and seven fresh and six altered plagioclase separates were analyzed for oxygen isotope compositions. In addition, three whole-rock gabbro samples from the Obatogamau Formation were analysed for comparison with the Doré Lake Complex samples. The sample selection was designed to assess the isotopic differences between least and most altered samples, and hence understand the effects of metamorphic alteration on the plagioclase oxygen isotope composition. Minerals were separated at the University of Windsor. Crushedsamples were cleaned with distilled water, after which the fresh plagioclase and altered plagioclase grains were hand-picked using a reflected binocular microscope (see Polat and Longstaffe 2014). Scanning electron microscope observations indicate that altered plagioclase grains were extensively recrystallized and replaced mainly by epidote group minerals. The alteration mineralogy was confirmed by powder XRD at the Laboratory for Stable Isotope Science, The University of Western Ontario (LSIS), London (Ontario), Canada. Most of the fresh plagioclase grains also contain 10 to $15 \%$ inclusions of epidote group minerals.

Oxygen-isotope analyses were carried out at LSIS. Approximately $8 \mathrm{mg}$ of sample powder were weighed into spring-loaded sample holders, evacuated overnight at ca. $150{ }^{\circ} \mathrm{C}$, and then placed into nickel reaction vessels and heated in vacuo at $300{ }^{\circ} \mathrm{C}$ for further 3 hours to remove surface water (see Polat and Longstaffe 2014; Zhou et al. 2016). The samples were then reacted overnight at ca. $580{ }^{\circ} \mathrm{C}$ with $\mathrm{ClF}_{3}$ to release silicate-bound oxygen (Borthwick and Harmon (1982) following Clayton and Mayeda (1963)). The oxygen was converted to $\mathrm{CO}_{2}$ over red-hot graphite, followed by isotopic measurement using a Micromass Optima II dual-inlet, stableisotope-ratio mass-spectrometer.

The oxygen isotopic data are reported as $\delta$-notation in parts per thousand (\%) relative to Vienna Standard Mean Ocean Water (VSMOW). Details of the calibration to VSMOW are given in Polat and Longstaffe (2014). The average reproducibility of $\delta^{18} \mathrm{O}$ for samples was $\pm 0.22 \%$ $(\mathrm{n}=4)$. Accuracy was determined using VSMOW-SLAP calibrated internal laboratory quartz, basalt and $\mathrm{CO}_{2}$ gas standards yielding $\delta^{18} \mathrm{O}$ of $+11.60 \pm 0.22 \%$ ( $\left.\mathrm{n}=7\right), 7.49 \pm 0.15 \%$ o $(\mathrm{n}=6)$ and $+10.20 \pm 0.10 \%$ o $(\mathrm{n}=7)$, respectively. These results compare well with their expected values of $+11.5 \%$ o, $+7.5 \%$ and $+10.3 \%$, respectively. 


\section{Petrography}

Representative photomicrographs and SEM-BSE images of the anorthosites, leucogabbros, gabbros and mafic dykes in the Doré Lake Complex are presented in Figs. 7 to 11. Although outcrop-scale cumulate textures are well preserved in the anorthosites and leucogabbros (Figs. 4 and 5), almost all of the primary igneous minerals have been extensively recrystallized in these rocks (Figs. 7-11). Despite the extensive recrystallization, pseudomorphs of cumulate plagioclase crystals and interstitial minerals are locally preserved (Figs. 5- 8). SEM-EDS analyses indicate that the plagioclase crystals are predominantly anorthite and albite (Figs. 9-11).

The anorthosites are composed mainly of anorthite + albite + epidote + chlorite + calcite + titanite \pm quartz \pm apatite \pm sericite \pm muscovite \pm rutile (Figs. 7 and 9). The leucogabbros are mineralogically similar to the anorthosite, consisting mainly of anorthite + albite + epidote + chlorite \pm sericite \pm calcite \pm actinolite \pm quartz \pm sericite \pm titanite (Figs. 7-9). Albite is replaced by muscovite and sericite in the samples that were collected in the vicinity of shear zones. Cumulate texture is only locally preserved in the gabbros (Fig. 7d). The gabbros are characterized by anorthite + albite + chlorite + epidote + titanite \pm rutile \pm quartz \pm pyrite \pm magnetite \pm ilmenite (Figs. 7, 8, 10 and 11). Plagioclase in the anorthosites, leucogabbros and gabbros is mainly replaced by anhedral to euhedral epidote (Figs. 9 and 10). In the anorthosites, leucogabbros and gabbros, albite occurs as anhedral patches within anhedral anorthite (Figs. 9 and 10). The mafic dykes consist of chlorite + albite + epidote + actinolite + quartz \pm titanite \pm magnetite \pm ilmenite (Figs. 7, 8, 10 and 11).

Basalts in the Obatogamau Formation are composed predominantly of chlorite + plagioclase + epidote \pm calcite \pm quartz \pm titanite \pm opaque minerals (Fig. 12). Because of extensive deformation and metamorphic recrystallization, relict igneous textures are preserved only in low-strain areas (Fig. 12a). Amygdular basalts contain 1-5 mm long calcite, quartz, and chlorite amygdules (Fig. 12d). The gabbros of the Obatogamau Formation consist of plagioclase + chlorite + epidote \pm calcite \pm quartz \pm titanite \pm opaque minerals (Fig. 12f). 
462

463

464

465

466

467

468

469

470

471

472

473

474

475

476

477

478

479

480

481

482

483

484

485

486

487

488

489

490

491

492

\section{Geochemical results}

Major and trace elements

Doré Lake Complex

Anorthosites

The anorthosites display large variations in $\mathrm{Fe}_{2} \mathrm{O}_{3}(0.9-8.8$ wt.\%), $\mathrm{MgO}(0.23-6.5$ wt.\%), $\mathrm{TiO}_{2}\left(0.06-2.45\right.$ wt.\%), $\mathrm{Na}_{2} \mathrm{O}\left(0.54-4.7\right.$ wt.\%) and $\mathrm{K}_{2} \mathrm{O}(0.01-2.99$ wt.\%) concentrations (Figs. 13 and 14; Supplementary Table 1). $\mathrm{SiO}_{2}$ varies between 36.6 and 49.1 wt.\% (Fig. 13; Supplementary Table 1). $\mathrm{Al}_{2} \mathrm{O}_{3}$ and $\mathrm{CaO}$ range from 24.1 to $31.0 \mathrm{wt} . \%$ and 8.4 to $17.7 \mathrm{wt} \%$, respectively (Supplementary Table 1). Nickel (4-144 pm), Cr (6-660 ppm), Co (2-46 ppm), V (6-110 ppm) and Sc (1-24 ppm) contents show large variations (Fig. 13; Supplementary Table 1). Large ion lithophile elements (e.g., $\mathrm{Rb}=0.3-81 \mathrm{ppm} ; \mathrm{Sr}=130-550 \mathrm{ppm}, \mathrm{Ba}=2-530 \mathrm{ppm}$; and $\mathrm{Li}=2.3-29 \mathrm{ppm}$ ) are characterized by substantial variations (Supplementary Table 1). Mgnumbers vary from 29 to 60 (Supplementary Table 1). $\mathrm{Al}_{2} \mathrm{O}_{3} / \mathrm{TiO}_{2}$ ratios span between 11 and 890. $\mathrm{Nb} / \mathrm{Ta}(11.2-26.1)$ ratios exhibit moderate variations, whereas $\mathrm{Zr} / \mathrm{Y}$ (0.8-63) ratios display very large variations.

On the basis of REE patterns, the anorthosites can be divided into four groups (Fig. 15; Supplementary Table 1). Group 1 is characterized by flat to slightly enriched LREE $\left(\mathrm{La} / \mathrm{Sm}_{\mathrm{cn}}=0.99-2.94 ; \mathrm{La} / \mathrm{Yb}_{\mathrm{cn}}=1.23-4.40\right)$ and slightly depleted $\mathrm{HREE}\left(\mathrm{Gd} / \mathrm{Yb}_{\mathrm{cn}}=1.14-1.34\right)$ patterns, variably negative $\mathrm{Nb}\left(\mathrm{Nb} / \mathrm{Nb}^{*}=0.17-0.60\right)$ and negative to slightly positive $\mathrm{Ti}$ $\left(\mathrm{Ti} / \mathrm{Ti}^{*}=0.34-1.06\right)$ anomalies (Fig. 15a; Supplementary Table 1). The group has large positive $\mathrm{Eu}\left(\mathrm{Eu} / \mathrm{Eu}^{*}=1.62-2.90\right), \mathrm{Sr}\left(\mathrm{Sr} / \mathrm{Sr}^{*}=5.08-9.00\right)$ and $\mathrm{Pb}\left(\mathrm{Pb} / \mathrm{Pb}^{*}=8.2-55\right)$ anomalies (Fig. 15a; Supplementary Table 1$)$. Cerium $\left(\mathrm{Ce} / \mathrm{Ce}^{*}=0.95-1.00\right)$ anomalies are minor to absent. Group 2 has slightly concave-up HREE and more fractionated LREE patterns ( $\mathrm{La} / \mathrm{Sm}_{\mathrm{cn}}=2.57-9.41$; $\left.\mathrm{Ga} / \mathrm{Yb}_{\mathrm{cn}}=0.96-3.21 ; \mathrm{La} / \mathrm{Yb}_{\mathrm{cn}}=4.74-57\right)$ than Group 1 (Fig. 15b; Supplementary Table 1). Like Group 1 anorthosites, Group 2 anorthosites display negative $\mathrm{Nb}\left(\mathrm{Nb} / \mathrm{Nb}^{*}=0.01-0.29\right)$ anomalies, whereas the $\mathrm{Eu}\left(\mathrm{Eu} / \mathrm{Eu}^{*}=2.50-7.70\right), \mathrm{Sr}(\mathrm{Sr} / \mathrm{Sr} *=13.2-25.0)$ and $\mathrm{Pb}\left(\mathrm{Pb} / \mathrm{Pb}{ }^{*}=55-150\right)$ anomalies are strongly positive (Fig. 15b; Supplementary Table 1). These anorthosites have small negative $\mathrm{Ce}\left(\mathrm{Ce} / \mathrm{Ce}^{*}=0.90-0.99\right)$ anomalies. Group 3 is represented by only one sample (DL2014-15) that has a moderately depleted LREE $\left(\mathrm{La} / \mathrm{Sm}_{\mathrm{cn}}=0.63\right)$ pattern, negative $\mathrm{Nb}\left(\mathrm{Nb} / \mathrm{Nb}^{*}=0.37\right)$ and $\mathrm{Zr}$ $\left(\mathrm{Zr} / \mathrm{Zr}^{*}=0.32\right)$ anomalies, and positive $\mathrm{Eu}\left(\mathrm{Eu} / \mathrm{Eu}^{*}=1.38\right), \mathrm{Pb}(\mathrm{Pb} / \mathrm{Pb} *=9.2)$ and $\mathrm{Sr}(\mathrm{Sr} / \mathrm{Sr}=4.03)$ anomalies (Fig. 15c). Group 4 has the following trace element characteristics: (1) depleted to 
slightly enriched LREE $\left(\mathrm{La} / \mathrm{Sm}_{\mathrm{cn}}=0.51-1.18 ; \mathrm{La} / \mathrm{Yb}_{\mathrm{cn}}=0.71-1.03\right)$ and moderately depleted $\operatorname{HREE}\left(\mathrm{Gd} / \mathrm{Yb}_{\mathrm{cn}}=1.12-1.40\right)$ patterns; (2) zero to positive $\mathrm{Eu}\left(\mathrm{Eu} / \mathrm{Eu}^{*}=0.98-3.26\right)$ and negative to minor positive $\mathrm{Ce}\left(\mathrm{Ce} / \mathrm{Ce} e^{*}=0.86-1.05\right)$ anomalies; (3) variably large positive $\mathrm{Pb}\left(\mathrm{Pb} / \mathrm{Pb}{ }^{*}=3.7-\right.$ 23 ) anomalies; and (4) negative to positive $\mathrm{Nb}\left(\mathrm{Nb} / \mathrm{Nb}^{*}=0.29-2.18\right)$ and $\mathrm{Ti}\left(\mathrm{Ti} / \mathrm{Ti}{ }^{*}=0.29-3.76\right)$ anomalies (Fig. 15d; Supplementary Table 1).

\section{Leucogabbros}

The leucogabbros have narrow variations in $\mathrm{SiO}_{2}\left(40.5-43.4\right.$ wt.\%) and $\mathrm{Al}_{2} \mathrm{O}_{3}(21.4-24.0$ wt.\%) and moderate variations in $\mathrm{Fe}_{2} \mathrm{O}_{3}$ (7.3-10.2 wt.\%) (Figs. 13 and 14; Supplementary Table 1). $\mathrm{CaO}$ (6.9-14.2\%), $\mathrm{MgO}$ (3.9-12.6 wt.\%), $\mathrm{Na}_{2} \mathrm{O}$ (0.72-2.38 wt.\%) and $\mathrm{K}_{2} \mathrm{O}$ (0.11-0.95 wt.\%) display large variations (Supplementary Table 1). $\mathrm{TiO}_{2}(0.05-0.29$ wt.\%) is strongly depleted, resulting in high $\mathrm{Al}_{2} \mathrm{O}_{3} / \mathrm{TiO}_{2}$ (81-420) ratios (Supplementary Table 1). Mg-numbers vary between 43 and 76 (Supplementary Table 1).

Based on their REE patterns, the leucogabbros are divided into three groups (Fig. 16a-c; Supplementary Table 1). Group 1 exhibits moderately fractionated REE ( $\mathrm{La} / \mathrm{Sm}_{\mathrm{cn}}=1.08-1.33$; $\left.\mathrm{Gd} / \mathrm{Yb}_{\mathrm{cn}}=1.22-1.44 ; \quad \mathrm{La} / \mathrm{Yb}_{\mathrm{cn}}=1.54-2.18\right)$ patterns, positive $\mathrm{Eu}\left(\mathrm{Eu} / \mathrm{Eu}^{*}=1.76-3.42\right), \mathrm{Pb}$ $(\mathrm{Pb} / \mathrm{Pb} *=2.6-10.5)$ and $\mathrm{Sr}\left(\mathrm{Sr} / \mathrm{Sr}^{*}=3.3-3.79\right)$ anomalies, and negative $\mathrm{Nb}\left(\mathrm{Nb} / \mathrm{Nb}^{*}=0.29-0.44\right)$ anomalies (Fig. 16a). Cerium $\left(\mathrm{Ce} / \mathrm{Ce}^{*}=1.00-1.03\right)$ anomalies are absent. Group 2 is characterized by more fractionated $\operatorname{LREE}\left(\mathrm{La} / \mathrm{Sm}_{\mathrm{cn}}=1.52-2.95 ; \mathrm{La} / \mathrm{Yb}_{\mathrm{cn}}=1.94-8.86\right)$ patterns than Group 1 and has slightly concave-up HREE ( $\left.\mathrm{Gd} / \mathrm{Yb}_{\mathrm{cn}}=1.13-1.70\right)$ patterns (Fig. 16b; Supplementary Table 1). It exhibits negative $\mathrm{Nb}\left(\mathrm{Nb} / \mathrm{Nb}^{*}=0.08-0.42\right)$ and $\mathrm{Zr}\left(\mathrm{Zr} / \mathrm{Zr}^{*}=0.26-0.89\right)$ anomalies, and positive $\mathrm{Eu}\left(\mathrm{Eu} / \mathrm{Eu}^{*}=2.95-3.68\right), \mathrm{Pb}\left(\mathrm{Pb} / \mathrm{Pb}^{*}=16.9-46.5\right)$ and $\mathrm{Sr}(\mathrm{Sr} / \mathrm{Sr} *=8.90-13.94)$ anomalies (Fig. 16b; Supplementary Table 1). Group 3 is represented by only one sample, displaying a fractionated $\operatorname{REE}\left(\mathrm{La} / \mathrm{Sm}_{\mathrm{cn}}=3.03 ; \mathrm{Gd} / \mathrm{Yb}_{\mathrm{cn}}=1.36 ; \mathrm{La} / \mathrm{Yb}_{\mathrm{cn}}=6.08\right)$ pattern, with positive $\mathrm{Eu}$ $\left(\mathrm{Eu} / \mathrm{Eu}^{*}=2.88\right), \mathrm{Pb}\left(\mathrm{Pb} / \mathrm{Pb}^{*}=10.8\right), \mathrm{Sr}\left(\mathrm{Sr} / \mathrm{Sr}^{*}=5.81\right)$ and $\mathrm{Ce}\left(\mathrm{Ce} / \mathrm{Ce}^{*}=1.12\right)$ anomalies, and negative $\mathrm{Nb}\left(\mathrm{Nb} / \mathrm{Nb}^{*}=0.06\right), \mathrm{Ti}\left(\mathrm{Ti} / \mathrm{Ti}{ }^{*}=0.67\right)$ and $\mathrm{Zr}\left(\mathrm{Zr} / \mathrm{Zr}{ }^{*}=0.36\right)$ anomalies (Fig. 16c).

\section{Gabbros}

Five gabbro samples were analyzed from the Doré Lake Complex (Supplementary Table 1). $\mathrm{SiO}_{2}$ spans from 42.9 to $51.6 \mathrm{wt} \%$ and $\mathrm{MgO}$ concentrations vary between 2.8 and $7.2 \mathrm{wt} \%$ (Figs. 13 and 14). These gabbros have moderate variations in $\mathrm{Fe}_{2} \mathrm{O}_{3}$ (11.0-16.5 wt.\%), $\mathrm{CaO}$ 
524 (8.5-11.6 wt.\%) and $\mathrm{TiO}_{2}\left(1.01-1.85\right.$ wt.\%), and large variations in $\mathrm{Na}_{2} \mathrm{O}\left(0.99-3.6\right.$ wt.\%), $\mathrm{K}_{2} \mathrm{O}$ 525 (0.02-0.84 wt.\%), Ni (11-82 ppm), Cr (7-251 ppm) and Ba (4-226 ppm) (Supplementary Table 526 1). Their Mg-numbers span from 29 to $51 . \mathrm{Al}_{2} \mathrm{O}_{3} / \mathrm{TiO}_{2}(8-15)$ and $\mathrm{Nb} / \mathrm{Ta}(14.0-17.2)$ ratios are 527 sub-chondritic.

528 The gabbros are divided into two groups on the basis of their REE patterns (Figs. 16d and 529 17a). Group 1 is characterized by flat-LREE $\left(\mathrm{La} / \mathrm{Sm}_{\mathrm{cn}}=0.95-1.03\right)$ and depleted HREE $530\left(\mathrm{Gd} / \mathrm{Yb}_{\mathrm{cn}}=1.13-1.27\right)$ patterns, and negative to positive $\mathrm{Eu}\left(\mathrm{Eu} / \mathrm{Eu}^{*}=0.79-2.91\right)$ anomalies (Fig. 531 16d). They have positive $\mathrm{Pb}\left(\mathrm{Pb} / \mathrm{Pb}^{*}=7.9-9.3\right)$ and negative $\mathrm{Nb}\left(\mathrm{Nb} / \mathrm{Nb}^{*}=0.50-0.61\right)$ and $\mathrm{Zr}$ 532 $\left(\mathrm{Zr} / \mathrm{Zr}^{*}=0.83-0.84\right)$ anomalies. Group 2 has more fractionated $\mathrm{REE}\left(\mathrm{La} / \mathrm{Sm}_{\mathrm{cn}}=0.95-1.03\right.$; $\mathrm{Gd} / \mathrm{Yb}_{\mathrm{cn}}=1.68-2.54 ; \mathrm{La} / \mathrm{Yb}_{\mathrm{cn}}=2.38-4.40$ ) patterns than Group 1 (Figs. 17d and 17a) but also negative $\mathrm{Nb}\left(\mathrm{Nb} / \mathrm{Nb}^{*}=0.15-0.68\right)$ and $\mathrm{Zr}\left(\mathrm{Zr} / \mathrm{Zr}{ }^{*}=0.30-0.89\right)$ anomalies like Group 1.

Mafic dykes

The mafic dykes are characterized by variable $\mathrm{SiO}_{2}\left(41.6-48.4\right.$ wt.\%), $\mathrm{TiO}_{2}(1.13-2.22$ 538 wt.\%), $\mathrm{CaO}$ (6.0-11.9 wt.\%), $\mathrm{MgO}$ (4.6-14.5 wt.\%), $\mathrm{Fe}_{2} \mathrm{O}_{3}$ (13.6-18.4 wt.\%) and $\mathrm{Na}_{2} \mathrm{O}(1.5-2.1$ wt.\%) contents (Figs. 13 and 14; Supplementary Table 1). Mg-numbers vary between 46 and 61. $\mathrm{Al}_{2} \mathrm{O}_{3} / \mathrm{TiO}_{2}$ ratios range from 5 to 12 . $\mathrm{Nb} / \mathrm{Ta}(12.8-16.4)$ ratios are sub-chondritic. Sample DL2014-17 is anomalous with a very different major element composition (Supplementary Table 1). In many major and trace element variation diagrams, the gabbros and mafic dykes plot in a separate field from the anorthosites and leucogabbros (Figs. 13 and 14).

Trace element patterns are consistent with two different groups (Fig. 17b and c). Group 1 546 characteristics: (1) flat to slightly enriched LREE patterns ( $\mathrm{La} / \mathrm{Sm}_{\mathrm{cn}}=1.02-1.12$ ) and slightly 547 depleted HREE $\left(\mathrm{Gd} / \mathrm{Yb}_{\mathrm{cn}}=1.16-1.26\right)$ patterns; (2) small negative $\mathrm{Eu}(\mathrm{Eu} / \mathrm{Eu} *=0.91-1.01)$ 548 anomalies; (3) large positive $\mathrm{Pb}(\mathrm{Pb} / \mathrm{Pb} *=3.7-6.7)$ anomalies; and (4) moderately negative $\mathrm{Nb}$ $549\left(\mathrm{Nb} / \mathrm{Nb}^{*}=0.49-0.54\right)$ and $\mathrm{Zr}\left(\mathrm{Zr} / \mathrm{Zr}{ }^{*}=0.80-0.87\right)$ anomalies (Fig. 17b; Supplementary Table 1). 550 Titanium $\left(\mathrm{Ti} / \mathrm{Ti}^{*}=0.92-1.02\right)$ anomalies are minor or absent. Group 2 has depleted to enriched 551 LREE $\left(\mathrm{La} / \mathrm{Sm}_{\mathrm{cn}}=0.53-1.57\right)$ and $\mathrm{HREE}\left(\mathrm{Gd} / \mathrm{Yb}_{\mathrm{cn}}=0.31-1.09\right)$ patterns, and positive Eu $552\left(\mathrm{Eu} / \mathrm{Eu}^{*}=1.39-1.46\right), \mathrm{Zr}\left(\mathrm{Zr} / \mathrm{Zr}{ }^{*}=5.44-6.40\right), \mathrm{Ti}\left(\mathrm{Ti} / \mathrm{Ti}^{*}=1.21-7.46\right)$ and $\mathrm{Nb}\left(\mathrm{Nb} / \mathrm{Nb}^{*}=1.48-\right.$ 553 1.77) anomalies (Fig. 17c; Supplementary Table 1). 
555

556

557

558

559

560

561

562

563

564

565

566

567

568

569

570

571

572

573

574

575

576

577

578

579

580

581

582

583

584

585

\section{Obatogamau Formation}

Basalts

The basalts of the Obatogamau Formation are characterized by moderately variable $\mathrm{SiO}_{2}$ (43.9-50.4 wt.\%), $\mathrm{Fe}_{2} \mathrm{O}_{3}\left(10.7-18.0\right.$ wt.\%) and $\mathrm{Al}_{2} \mathrm{O}_{3}$ (11.9-15.2 wt.\%) contents (Figs. 13 and 14; Supplementary Table 2). $\mathrm{MgO}$ (2.8-7.6 wt.\%), $\mathrm{TiO}_{2}$ (0.91-2.10 wt.\%), $\mathrm{CaO}$ (4.1-12.2 wt.\%), $\mathrm{Na}_{2} \mathrm{O}\left(0.18-3.52\right.$ wt.\%), $\mathrm{K}_{2} \mathrm{O}(<0.01-0.24$ wt.\%), Rb (0.20-31.6 ppm), Ba (5-710 ppm) and $\mathrm{Sr}$ (50-460 ppm) exhibit large variations (Figs. 13 and 14; Supplementary Table 2). There are also large variations in Ni (25-112 ppm) and Cr (11-290 ppm), whereas V (220-356 ppm), Sc (28$47 \mathrm{ppm}$ ) and Co (31-65 ppm) display smaller variations (Supplementary Table 2). Mg-numbers range from 33 to 54 (Supplementary Table 2). The ratios of $\mathrm{Al}_{2} \mathrm{O}_{3} / \mathrm{TiO}_{2}$ (7-15) are subchondritic. $\mathrm{Zr} / \mathrm{Y}(2.3-3.3)$ and $\mathrm{Th} / \mathrm{Yb}(0.08-0.19)$ ratios are consistent with a tholeiitic composition (Supplementary Table 2; see Ross and Bédard 2009). The basalts have the following trace element characteristics: (1) slightly depleted to slightly enriched LREE $\left(\mathrm{La} / \mathrm{Sm}_{\mathrm{cn}}=0.80-1.13 ; \mathrm{La} / \mathrm{Yb}_{\mathrm{cn}}=0.90-1.33\right)$ patterns; (2) flat to variably depleted HREE $\left(\mathrm{Gd} / \mathrm{Yb}_{\mathrm{cn}}=1.03-1.52\right)$ patterns; (3) negative to positive $\mathrm{Eu}\left(\mathrm{Eu} / \mathrm{Eu}^{*}=0.83-1.14\right)$ and $\mathrm{Sr}$ $(\mathrm{Sr} / \mathrm{Sr} *=0.50-5.52)$ anomalies; (4) mainly small negative to positive $\mathrm{Zr}(\mathrm{Zr} / \mathrm{Zr} *=0.80-1.08)$ and Ti (Ti/Ti*=0.81-1.04) anomalies; (5) mainly large positive $\mathrm{Pb}(\mathrm{Pb} / \mathrm{Pb} *=0.89-13.6)$ anomalies; and (6) negative $\mathrm{Nb}\left(\mathrm{Nb} / \mathrm{Nb}^{*}=0.53-0.72\right)$ anomalies (Fig. 18; Supplementary Table 2).

Two amygdular basalt samples show small ranges of $\mathrm{SiO}_{2}\left(49.8-51.1\right.$ wt.\%), $\mathrm{Al}_{2} \mathrm{O}_{3}(13.7-$ 14.0 wt.\%), $\mathrm{Na}_{2} \mathrm{O}$ (2.2-2.4 wt.\%), $\mathrm{CaO}$ (10.8-12.9 wt.\%), $\mathrm{TiO}_{2}(0.72-0.74$ wt.\%), Sc (28-29 ppm), Cr (125-127 ppm) and V (171-179 ppm) concentrations (Supplementary Table 2). MgO (2.3-3.3 wt.\%), $\mathrm{Fe}_{2} \mathrm{O}_{3}$ (7.7-11.0 wt.\%), $\mathrm{K}_{2} \mathrm{O}$ (0.22-0.38 wt.\%), Ni (148-190 ppm), Ba (43-67 ppm) and Sr (87-126 ppm) display moderate variations (Supplementary Table 2). They have higher $\mathrm{Al}_{2} \mathrm{O}_{3} / \mathrm{TiO}_{2}(18-19)$ and $\mathrm{Zr} / \mathrm{Y}$ (3.7-4.2) ratios than the basalts. Overall, the amygdular basalt samples have trace element patterns similar to those of the basalts, but display larger variations in $\mathrm{La} / \mathrm{Yb}_{\mathrm{cn}}=1.18-2.50$ and $\mathrm{Zr} / \mathrm{Zr}^{*}=0.72-1.20$ ratios (Supplementary Table 2). $\mathrm{Th} / \mathrm{Yb}$ and $\mathrm{Zr} / \mathrm{Y}$ ratios are consistent with a tholeiitic affinity for the amygdular basalt (Supplementary Table 2; $c f$., Ross and Bédard 2009). 
$\mathrm{SiO}_{2}(44.5-50.3 \mathrm{wt} . \%)$ contents of the gabbros are similar to those of the spatially associated basalts (43.9-51.1 wt.\%) (Fig. 13; Supplementary Table 2). Overall, however, the gabbros have variably higher $\mathrm{MgO}$ (5.6-8.6 wt.\%) contents than the basalts (2.3-7.6 wt.\%) (Figs. 13 and 14; Supplementary Table 2). Other major elements have similar ranges in both rock types (Supplementary Table 2). The gabbros display a wide range of Ni (16-124 ppm), Cr (5-247 ppm), V (247-419 ppm), Cu (39-207 ppm), Ba (8-125 ppm), Sr (145-291 ppm) and Zn (83-169 ppm) concentrations. In contrast, they have a narrow range of Sc (41-49 ppm), Co (39-57 ppm) and Ga (16-19 ppm) contents. Sample DL2014-89 is anomalous in that it has the lowest Mgnumber (38 versus 52-58) and $\mathrm{Al}_{2} \mathrm{O}_{3} / \mathrm{TiO}_{2}(8)$ ratio among five samples.

The gabbros have moderately depleted to flat LREE $\left(\mathrm{La} / \mathrm{Sm}_{\mathrm{cn}}=0.75-1.03\right)$ and $\mathrm{HREE}$ $\left(\mathrm{Gd} / \mathrm{Yb}_{\mathrm{cn}}=0.94-1.22\right)$ patterns (Fig. 18c). On the N-MORB normalized diagrams, they share the positive $\mathrm{Pb}\left(\mathrm{Pb} / \mathrm{Pb}^{*}=3.8-14.9\right)$ and $\mathrm{Sr}\left(\mathrm{Sr} / \mathrm{Sr}^{*}=1.8-5.0\right)$ anomalies and the negative $\mathrm{Nb}$ $\left(\mathrm{Nb} / \mathrm{Nb}^{*}=0.51-0.70\right)$ and $\mathrm{Zr}\left(\mathrm{Zr} / \mathrm{Zr}^{*}=0.83-0.95\right)$ anomalies of the spatially associated basalts (Fig. 18). Cerium $\left(\mathrm{Ce} / \mathrm{Ce}^{*}=0.98-1.02\right)$ and $\mathrm{Eu}\left(\mathrm{Eu} / \mathrm{Eu}^{*}=1.0-1.06\right)$ anomalies are absent. Like the basalts, the gabbros have a tholeiitic affinity as suggested by their $\mathrm{Th} / \mathrm{Yb}(0.07-0.14)$ and $\mathrm{Zr} / \mathrm{Y}$ (2.3-2.9) ratios (Supplementary Table 2; cf., Ross and Bédard 2009).

\section{Radiogenic isotopes}

Sm-Nd isotopes

The $\mathrm{Sm}$ and $\mathrm{Nd}$ isotopic compositions of the anorthosites, leucogabbros, gabbros and mafic dykes in the Doré Lake Complex are presented in Supplementary Table 3. Initial $\varepsilon N d$ values for the samples are calculated at $2728 \mathrm{Ma}$, using the crystallization age of the complex (see Mortensen 1993). On the ${ }^{147} \mathrm{Sm} /{ }^{144} \mathrm{Nd}$ versus ${ }^{143} \mathrm{Nd} /{ }^{144} \mathrm{Nd}$ regression diagram, cogenetic anorthosite and leucogabbro samples yield an errorchron age of 2624 \pm 160 Ma (MSWD=78) (Fig. 19a). This errorchron age agrees, within analytical uncertainties, with the ca. $2728 \mathrm{Ma}$ age obtained for quartz-bearing pyroxenites and granophyres of the Doré Lake Complex (Mortensen 1993). The ca. $2700 \mathrm{Ma}$ reference isochron obtained from fresh igneous pyroxene and plagioclase in mafic and ultramafic rocks of the Southern Volcanic Zone (see Machado et al. 1986) is shown on the regression diagram for comparison. The anorthosites display moderate variations in ${ }^{143} \mathrm{Nd} /{ }^{144} \mathrm{Nd}(0.511274-0.512879)$ and ${ }^{147} \mathrm{Sm} /{ }^{144} \mathrm{Nd}(0.103-0.198)$ ratios, yielding 
617 initial $\varepsilon N d$ values between +2.6 to +6.2 (Supplementary Table 3). Depleted mantle model ages of 618 the anorthosites range from 2578 to $2997 \mathrm{Ma}$ (Supplementary Table 3). The leucogabbros have a 619 smaller range of initial $\varepsilon N d(+3.6$ to +4.5$)$ and depleted mantle model ages $(2676-2781 \mathrm{Ma})$ in

620

621

622

623

624

625

626

627

628

629

630

631

632

633

634

635

636

637

638

639

640

641

642

643

644

645

646

647 comparison to the anorthosites (Supplementary Table 3). Two gabbro samples yielded +2.6 to +3.4 initial $\varepsilon N d$ values and 3113-3128 Ma model ages (Supplementary Table 3). The initial $\varepsilon N d$ $(+3.0$ to +3.8$)$ values of the mafic dykes are comparable to those of the gabbros, whereas their model ages (2805-3003 Ma) are slightly lower than those of the gabbros. The gabbros of the Obatogamau Formation have ${ }^{143} \mathrm{Nd} /{ }^{144} \mathrm{Nd}=0.512602-0.513095$ and ${ }^{147} \mathrm{Sm} /{ }^{144} \mathrm{Nd}=0.187-0.211$, yielding initial $\varepsilon N d=+2.8$ to +4.0 (Supplementary Table 3). Depleted mantle model ages for the Obatogamau gabbros range from 2986 to 3033 Ma (Supplementary Table 3).

\section{$U-T h-P b$ isotopes}

The anorthosites have moderate variations in ${ }^{206} \mathrm{~Pb} /{ }^{204} \mathrm{~Pb}(13.416-15.371)$ and ${ }^{208} \mathrm{~Pb} /{ }^{204} \mathrm{~Pb}$ (33.223-36.159) ratios (Supplementary Table 4). The ${ }^{207} \mathrm{~Pb} /{ }^{204} \mathrm{~Pb}(14.455-14.949)$ ratios display small variations. The leucogabbros have variably higher ${ }^{206} \mathrm{~Pb} /{ }^{204} \mathrm{~Pb}(15.159-17.193),{ }^{207} \mathrm{~Pb} /{ }^{204} \mathrm{~Pb}$ (14.758-15.506) and ${ }^{208} \mathrm{~Pb} /{ }^{204} \mathrm{~Pb}(34.653-37.221)$ ratios than the anorthosites (Supplementary Table 4). The $\mathrm{Pb}$ isotopic compositions of the gabbros $\left({ }^{206} \mathrm{~Pb} /{ }^{204} \mathrm{~Pb}=14.758-15.041\right.$; $\left.{ }^{207} \mathrm{~Pb} /{ }^{204} \mathrm{~Pb}=14.735-14.907 ; \quad{ }^{208} \mathrm{~Pb} /{ }^{204} \mathrm{~Pb}=34.769-35.026\right)$ and the mafic dykes $\left({ }^{206} \mathrm{~Pb} /{ }^{204} \mathrm{~Pb}=14.602-15.148 ; \quad{ }^{207} \mathrm{~Pb} /{ }^{204} \mathrm{~Pb}=14.752-14.860 ; \quad{ }^{208} \mathrm{~Pb} /{ }^{204} \mathrm{~Pb}=34.215-35.223\right) \quad$ are similar to those of the leucogabbros (Supplementary Table 4). The cogenetic anorthosites and leucogabbro yield an errorchron age of $3326 \pm 270 \mathrm{Ma}(\mathrm{MSWD}=61)$ (Fig. 19b) that is much older than the ca. 2728 Ma crystallization age of the Doré Lake Complex (Mortensen 1993). The 2736 $\mathrm{Ma}{ }^{206} \mathrm{~Pb} /{ }^{204} \mathrm{~Pb}-{ }^{207} \mathrm{~Pb} /{ }^{204} \mathrm{~Pb}$ reference isochron from Machado et al. (1986) is also plotted for comparison (Fig. 19b). The $\mathrm{Pb}$ isotopic compositions of the gabbro samples from the Obatogamau Formation are similar to those of the Doré Lake Complex gabbros $\left({ }^{206} \mathrm{~Pb} /{ }^{204} \mathrm{~Pb}=14.768-15.457 ; \quad{ }^{207} \mathrm{~Pb} /{ }^{204} \mathrm{~Pb}=14.856-14.870 ; \quad{ }^{208} \mathrm{~Pb} /{ }^{204} \mathrm{~Pb}=34.575-35.458\right)$ (Supplementary Table 4).

\section{$R b$-Sr isotopes}

The anorthosites and gabbros of the Doré Lake Complex display a wide range of ${ }^{87} \mathrm{Rb} /{ }^{86} \mathrm{Sr}$ and ${ }^{87} \mathrm{Sr} /{ }^{86} \mathrm{Sr}$ ratios (Supplementary Table 5). Initial (at $2728 \mathrm{Ma}$ ) ratios of the anorthosites range 
648

649

650

651

652

653

654

655

656

657

658

659

660

661

662

663

664

665

666

667

668

669

670

671

672

673

674

675

676

677

678

from 0.692025 to 702293 . The leucogabbros (0.705728-0.716366), gabbros $(0.703640-$ $0.705555)$ and mafic dykes $(0.702305-0.705285)$ have smaller range of ${ }^{87} \mathrm{Sr} /{ }^{86} \mathrm{Sr}$ ratios the anorthosite (0.702732-0.726495 (Supplementary Table 5). When the cogenetic anorthosite and leucogabbro samples are regressed on the ${ }^{87} \mathrm{Rb} /{ }^{86} \mathrm{Sr}$ versus ${ }^{87} \mathrm{Sr} /{ }^{86} \mathrm{Sr}$ diagram, they yield an errorchron age of $1995 \pm 150 \mathrm{Ma}(\mathrm{MSWD}=53543)$ (Fig. 19c). This age is substantially lower than the ca. 2728 Ma crystallization age of the Doré Lake Complex (Mortensen 1993). The ca. 2700 $\mathrm{Ma}{ }^{87} \mathrm{Rb}^{86}{ }^{86}{ }^{-87} \mathrm{Sr} /{ }^{86} \mathrm{Sr}$ isochron line from Machado et al. (1986) is also presented for comparison. The gabbros of the Obotagamau Formation have a narrower range of ${ }^{87} \mathrm{Sr} /{ }^{86} \mathrm{Sr}$ (0.702151-0.702295) ratios than the samples from the Doré Lake Complex (Supplementary Table 5) and their initial ${ }^{87} \mathrm{Sr} /{ }^{86} \mathrm{Sr}$ ratios range from 0.701574 to 0.702089 .

\section{O isotopes}

The whole-rock $\mathrm{O}$ isotope compositions of the anorthosites and gabbros, and of the fresh and altered plagioclase separates are presented in Supplementary Table 6. As shown in the petrography section, all rock types in the Dore Lake Complex and the Obatogamau Formation underwent extensive metamorphic recrystallization, resulting in widespread epidotization and chloritization (Figs. 7-12). Scanning electron microscope observations indicate that most plagioclase grains in the anorthosites, leucogabbros and gabbros are recrystallized and contain 10-30 $\mu \mathrm{m}$ long inclusions of epidote group minerals (Figs. 8-13). We could not obtain $100 \%$ fresh plagioclase grains because of the widespread presence of epidote inclusions. Grains defined as "fresh" still contain $10-15 \%$ epidote. Altered grains contain mainly $>80 \%$ epidote group minerals.

The $\delta^{18} \mathrm{O}$ of the anorthosites range from +6.05 to $+7.85 \%$ (average $=+6.8 \%$ ). The $\delta^{18} \mathrm{O}$ $(+6.27$ to $+7.13 \%$; average $=+6.8 \%)$ of the gabbros is similar to the anorthosites. Fresh and altered plagioclase separates yielded $\delta^{18} \mathrm{O}$ ranging from +6.22 and $+7.13 \%$ (average $=+6.8 \%$ ) and +4.77 and $+7.96 \%$ (average $=+6.6 \%$ ), respectively. The gabbros from the Obatogamau Formation have slightly higher $\delta^{18} \mathrm{O}(+7.27$ to $+7.97 \%$; average $=+7.66 \%)$ than the anorthosite and gabbros from the Doré Lake Complex. 


\section{Discussion}

Effects of metamorphism on element mobility

Field and petrographic observations indicate that the Dore Lake Complex underwent extensive recrystallization under greenschist facies metamorphic conditions (Figs. 4-11), leading to extensive replacement of primary igneous minerals mainly by epidote group minerals (e.g., epidote, clinozoisite) and chlorite. Although cumulate textures are well preserved in many parts of the complex, almost all primary igneous minerals have been replaced by secondary metamorphic minerals (Figs. 4-11). Similarly, the rocks in the Roy Group were metamorphosed under mainly greenschist facies conditions (Fig. 12) (Daigneault et al. 1990; Bédard et al. 2009; Leclerc et al. 2011; this study). Accordingly, the effects of metamorphic alteration on the geochemistry of the Doré Lake Complex and the Roy Group need to be assessed before any petrogenetic interpretation. Given that the effects of metamorphism on the Roy Group and the Cummings Complex were discussed in detail by Leclerc et al. (2011) and Bédard et al. (2009), respectively, we focus here on the Doré Lake Complex. All samples analyzed for this study record the effects of a metamorphic overprint. Field and petrographic observations, however, indicate that the degree of metamorphic alteration varies from sample to sample, and outcrop to outcrop. Geochemically altered samples are identified as "least altered" and "most altered" samples using the magnitude of their $\mathrm{Ce}$ anomalies (i.e., $\mathrm{Ce} / \mathrm{Ce} *<0.9$ or $\mathrm{Ce} / \mathrm{Ce} *>1.1$ ) and the extent of their carbonate and silica alteration (see Polat and Hofmann 2003). Samples that are identified as "most altered" are not used for petrogenetic interpretation. Scanning electron microscope BSE images and EDS analyses indicate that "most altered" samples contain higher abundances of calcite, titanite, rutile and ilmenite (Figs. 8-11). Widespread occurrences of epidote and chlorite suggest that the Doré Lake Complex and the Roy Group underwent extensive hydrothermal alteration, resulting high LOI (3-10 wt.\%) values (Figs. 4-12; Supplementary Tables 1 and 2).

Most large ion lithophile elements such as $\mathrm{K}_{2} \mathrm{O}, \mathrm{Na}_{2} \mathrm{O}, \mathrm{Rb}, \mathrm{Ba}, \mathrm{Sr}, \mathrm{Pb}$ and $\mathrm{Li}$ display large variations in the same rock type (Supplementary Tables 1 and 2), which is consistent with their extensive mobility during metamorphic alteration ( $c f$., Ludden et al. 1982; Polat and Hofmann

708 2003; Ordóñez-Calderón et al. 2008, 2011). Similarly, some transition metals such as Ni, Cr and 709 V show large scatter in the same rock type, suggesting the high mobility of these elements during 
metamorphism. The most resistant elements to metamorphic alteration are Th, REE and HFSE. Incoherent trace element patterns in the "most altered" samples indicate that Th, REE and HFSE were also variably mobile in these samples (Figs. 15d, 16c, 17c, 18b). Group 4 anorthosites, Group 3 leucogabbros and Group 2 mafic dykes and gabbros are designated as "most altered" on the basis of petrographic observations, the magnitude of Ce anomalies, and incoherent trace element patterns (Figs. 15-17). "Most altered" basalts in the Obatogamau Formation contain 5 to 10\% quartz and 5-10\% calcite amygdules, and 10-15\% epidote (Figs. 12d, 12e, 18b).

Large scatter in the ${ }^{87} \mathrm{Rb} /{ }^{86} \mathrm{Sr},{ }^{87} \mathrm{Sr} /{ }^{86} \mathrm{Sr},{ }^{206} \mathrm{~Pb} /{ }^{204} \mathrm{~Pb},{ }^{207} \mathrm{~Pb} /{ }^{204} \mathrm{~Pb}$ and ${ }^{208} \mathrm{~Pb} /{ }^{204} \mathrm{~Pb}$ ratios, and the $3326 \pm 270 \mathrm{Ma} \mathrm{Pb}-\mathrm{Pb}$ and $1935 \pm 150 \mathrm{Ma} \mathrm{Rb}-\mathrm{Sr}$ errochron ages indicate that the $\mathrm{Rb}-\mathrm{Sr}$ and U$\mathrm{Th}-\mathrm{Pb}$ isotope systems were open during metamorphism. Therefore, these systems are not used in petrogenetic interpretation. In contrast, the ${ }^{147} \mathrm{Sm} /{ }^{144} \mathrm{Nd}-{ }^{143} \mathrm{Nd} /{ }^{144} \mathrm{Nd}(2624 \pm 160 \mathrm{Ma})$ errorchron age, within uncertainty, agrees with the ca. $2728 \mathrm{Ma}$ zircon $\mathrm{U}-\mathrm{Pb}$ age of the quartzbearing pyroxenite and granophyre (Mortensen 1993). This suggests that the $\mathrm{Sm}-\mathrm{Nd}$ isotope system was more robust than the $\mathrm{Rb}-\mathrm{Sr}$ and $\mathrm{U}-\mathrm{Pb}$ isotope systems during metamorphic recrystallization. Nonetheless, the large uncertainty in the $2624 \pm 160 \mathrm{Ma}$ errorchron age and MSWD (78) suggest that the Sm-Nd system also underwent some disturbance during metamorphism. The samples collected from high-strain locations contain $15-20 \%$ sericite and muscovite (Figs. 9 and 11), reflecting alkaline metasomatism. Metasomatized (e.g., DL2014-79) and sheared (DL2014-86 and DL2014-87) samples have initial $\varepsilon N d$ values $>+5$. Accordingly, we attribute these high initial $\varepsilon N d$ values to the fractionation of $\mathrm{Sm} / \mathrm{Nd}$ during metamorphism and deformation, rather than to extremely depleted mantle-source domains beneath the Northern Volcanic Zone of the Abitibi subprovince.

The $\delta^{18} \mathrm{O}$ of the anorthosites $(+6.05$ to $+7.85 \%$ ) and fresh plagioclase $(+6.22$ to $+7.11 \%$ ) separates are similar to the isotopic composition of mantle-derived, primary igneous plagioclase (cf., Eiler 2001). Similarly, they are comparable to the $\delta^{18} \mathrm{O}$ of the $2970 \mathrm{Ma}$ Fiskenæsset and the ca. 2720 Ma Bad Vermilion Lake anorthosite complexes (Polat and Longstaffe 2014; Zhou et al. 2016). The much wider range of $\delta^{18} \mathrm{O}$ in the altered plagioclase separates $(+4.77$ to $+7.96 \%$ o $)$ is consistent with alteration over a range of metamorphic conditions, with the lowest values interpreted to be the product of high-temperature hydrothermal alteration ( $c f$., Manning et al. 1996; Bosch et al. 2004). $\delta^{18} \mathrm{O}$ values between +7.16 and +7.96 in altered plagioclase reflect low-temperature $\left(<300^{\circ} \mathrm{C}\right)$ hydrothermal alteration ( $c f$., Staudigel 2003). 
Mantle source characteristics and petrogenesis

743

744

745

746

747

748

749

750

751

752

753

754

755

756

757

758

759

760

761

762

763

764

765

766

767

768

769

770

771

Understanding the mantle source characteristics and petrogenesis of layered intrusions is essential for deciphering their geodynamic setting. The large positive initial $\varepsilon N d$ values of the Doré Lake Complex $(\varepsilon \mathrm{Nd}=+2.6$ to +5.0$)$ and the Roy Group $(\varepsilon \mathrm{Nd}=+2.8$ to +4.0$)$ are consistent with long-term depleted mantle-source compositions for these rock associations (Fig. 20; Supplementary Table 3). The $\mathrm{Nd}$ and $\mathrm{O}$ isotopic compositions of the Doré Lake Complex and Obatogamau Formation rule out any significant crustal contamination (Supplementary Tables 3 and 6). Similarly, the $\mathrm{Nd}$ isotopic compositions of volcanic rocks $(\varepsilon \mathrm{Nd}=+2.0$ to +5.0$)$ and TTGs $(\varepsilon \mathrm{Nd}=+1.0$ to +3.7$)$ in different parts of the Abitibi subprovince are collectively consistent with depleted mantle sources and rule out any significant contamination of mantle-derived magmas by older continental crust (Dupré et al. 1984; Machado et al. 1986; Vervoort et al. 1994; Dostal and Mueller 1996; Lahaye and Arndt 1996; Bédard and Ludden 1997; Lesher et al. 1997; Davis et al. 2000; Ayer et al. 2002). Collectively, these results suggest that the entire subprovince originated predominantly from depleted mantle sources between 2750 and $2680 \mathrm{Ma}$. The higher $\varepsilon \mathrm{Nd}$ values $(+5.0)$ might represent either small scale heterogeneities in the mantle or $\mathrm{Sm} / \mathrm{Nd}$ fractionation during metamorphism ( $c f$. ., Lahaye and Arndt 1996). The presence of inherited zircon grains in younger magmatic rocks in the Abitibi subprovince is consistent with the reworking of 10-50 Ma older rocks during younger tectono-magmatic events (Ayer et al. 2002).

Rocks analyzed for this study plot as two distinct suites on many binary major and trace element diagrams (Figs. 13 and 14). Suite 1 includes the anorthosites and leucogabbros of the Doré Lake Complex, whereas Suite 2 consists of the gabbros and mafic dykes of the Doré Lake Complex plus the basalts and gabbros of the Obatagamaou Formation in the Roy Group. These geochemical characteristics suggest the presence of two different magmatic suites in the Doré Lake Complex. Previous geochemical studies have suggested a calc-alkaline affinity for the Doré Lake Complex and the felsic rocks of the Waconichi Formation in the Roy Group, and a tholeiitic affinity for the basalts of the Obatogamau Formation (Bédard et al. 2009; Leclerc et al. 2011). Our data concur with these previous studies. Field relationships indicate that the gabbros and mafic dykes in the Dore Lake Complex, at least the ones sampled by this study, are younger than the anorthosites and leucogabbros (Figs. 5 and 6), suggesting that they intruded after 2728 Ma. Although the absolute ages of these gabbros and mafic dykes are currently unknown, their 
772 depleted mantle model ages are consistent with an Archean origin (Supplementary Table 3).

773 Given the presence of geochemically and mineralogically similar rock types in the middle and 774 upper sections of the Roy Group (Fig. 3; Bédard et al. 2009; Leclerc et al. 2011), the gabbros and 775 mafic dykes in the Doré Lake Complex are likely to be the counterparts of similar rock types in 776 the Roy Group. The mafic dykes might also represent the feeder system of the mafic volcanic 777 rocks in the Roy Group. We do not claim, however, that all gabbros in the Dore Laké Complex 778 have a different magmatic origin from the anorthosites and leucogabbros in the complex. Our 779 samples, except DL2014-37, were collected from gabbroic pods rather than gabbros interlayered 780 with the anorthosites and leucogabbros. The large positive initial $\varepsilon \mathrm{Nd}$ values of the gabbro pods $(\varepsilon \mathrm{Nd}=+2.6$ to +3.4$)$ and mafic dykes $(\varepsilon \mathrm{Nd}=+3.6$ to +3.8$)$ in the Doré Lake Complex are similar

782 783 784 785 786 787 788 789 790 791 792 793 794 795 796 797 798 799 800 801 802

to those of the gabbros $(\varepsilon \mathrm{Nd}=+2.8$ to +4.0$)$ of the Obatogamau Formation, consistent with longterm depleted mantle sources, as found for mafic rocks in other parts of the Abitibi subprovince (see Ayer et al. 2002).

Different REE patterns (Figs. 15 and 16) for the least altered anorthosites and leucogabbros likely reflect different crystal mush compositions rather than different source compositions, although different depths of partial melting cannot be ruled out. Melts of the samples with $\mathrm{Gd} / \mathrm{Yb}_{\mathrm{cn}}>1.3$ likely originated at depths of garnet stability $(>80 \mathrm{~km})$.

All rock types analysed for this study share the negative $\mathrm{Nb}$ anomalies, relative to LREE and Th, of modern subduction zone-derived igneous rocks ( $c f$., Saunders et al. 1991; Hawkesworth et al. 1993; Murphy 2007). Similarly, the mafic to felsic volcanic rocks of the Roy Group (Leclerc et al. 2011) and the mafic to ultramafic sills of the Cummings Complex (Bédard et al. 2009) share the negative $\mathrm{Nb}$ anomalies of modern arc magmas. In addition, model melt compositions from the Roy Group and Cummings Complex sills also display variable $\mathrm{Nb}$ depletion relative to Th and La on trace element diagrams (see Figs. 12 in Bédard et al. 2009 Bédard et al. 2009). However, Bédard et al. (2009) and Leclerc et al. (2011) did not attribute the origin of the negative $\mathrm{Nb}$ anomalies in the Cummings Complex and the Roy Group to any particular tectonic setting.

Trace element inversion calculations presented by Bédard et al. (2009) for the Doré Lake Complex are consistent with a dominantly calc-alkaline composition. On the basis of similar ages and geochemical affinities, Bédard et al. (2009) and Leclerc et al. (2011) suggested that the Waconichi and the Doré Lake Complex are genetically linked in that the Doré Lake Complex 
represents the magma chamber for the felsic tuffs of the Queylus and Allard Members of the Waconichi Formation.

Bédard et al. (2009) used the equilibrium distribution method (EDM) and trapped melt fraction (TMF) method to determine the composition of the melts from which the cumulate rocks in the Roy Group and Doré Lake Complex were derived by fractional crystallization. Calculated model melt compositions for their sample 3001a have slightly-enriched LREE patterns, positive $\mathrm{Eu}$ anomalies, strongly enriched $\mathrm{Th}$, and large negative $\mathrm{Zr}$ and $\mathrm{Nb}$ anomalies on an N-MORBnormalized diagram (see Fig. 12 in Bédard et al. 2009). Calculated model melt compositions for sample 3001b of Bédard et al. (2009) is characterized by strongly-enriched LREE and Th patterns, positive $\mathrm{Eu}$ anomalies, and large negative $\mathrm{Zr}$, $\mathrm{Ti}$ and $\mathrm{Nb}$ anomalies (see Fig. 12 in Bédard et al. 2009). These patterns are based on realistic assumptions and robust calculations; therefore, they are likely representative of the melts from which the anorthosites and leucogabbros of the Doré Lake Complex were derived, providing important constraints on the melt composition of the complex. As pointed out by Bédard et al. (2009), model melts patterns calculated for the Doré Lake Complex rocks are very similar to those for the calc-alkaline volcanic and pyroclastic rocks of the Waconichi Formation, suggesting a co-genetic relationship between the two suites of rocks. Trace element patterns of calculated melt compositions for the Doré Lake Complex are indistinguishable from those of modern arc magmas (see Murphy 2007).

Although the anorthosites and leucogabbros of the Doré Lake Complex share the subduction zone trace element systematics of the basalts and gabbros of the Obatogamau Formation (Figs. 15, 16 and 18), a direct petrogenetic link through fractional crystallization between the two suites appears unlikely for the following three main reasons: (1) the parental magmas to the anorthosites and leucogabbros of the Doré Lake Complex have a calc-alkaline affinity (Bédard et al. 2009), whereas the parental magmas to the Obatogamau basalts and gabbros have a tholeiitic affinity (Leclerc et al. 2011 and this study); (2) the anorthosites and leucogabbros of the Doré Lake Complex and the basalts and gabbros of the Obatogamau Formation plot in different fields on $\mathrm{SiO}_{2}$ versus $\mathrm{Al}_{2} \mathrm{O}_{3}, \mathrm{Fe}_{2} \mathrm{O}_{3}, \mathrm{Sc}, \mathrm{TiO}_{2}, \mathrm{Zr}$ and $\mathrm{Nb}$ binary diagrams (Figs. 13 and 14); and (3) the Obatogamau samples do not plot along the same fractionation trend as the Doré Lake anorthosites and leucogabbros on $\mathrm{MgO}$ versus $\mathrm{Fe}_{2} \mathrm{O}_{3}$ and $\mathrm{Al}_{2} \mathrm{O}_{3}$, and on $\mathrm{Al}_{2} \mathrm{O}_{3}$ versus $\mathrm{Fe}_{2} \mathrm{O}_{3}$ diagrams (Fig. 14). Collectively, we suggest that the Doré 
Lake Complex and the spatially associated basalts and gabbros of the Obatogamau Formation formed in a similar tectonic setting but had different petrogenetic origins.

\section{Geodynamic setting}

Although the Abitibi subprovince is one of the most studied Archean terrains in the world, its geodynamic origin is still a subject of intense debate (Thurston et al. 2002; Ayer et al. 2002; Daigneault et al. 2002; Moyen and van Hunen 2012; Bédard et al. 2013; Wyman 2013). Numerous field and geochemical studies (Desrochers et al. 1993; Kimura et al. 1993; Sutcliffe et al. 1993; Jackson et al. 1994; Dostal and Mueller 1996, 1997; Mueller et al. 1996; Bédard and Ludden 1997; Lacroix et al. 1998; Calvert and Ludden 1999; Wyman 1999, 2013; Chown et al. 2002; Wyman et al. 2002; Daigneault et al. 2002, 2004; Frieman et al. 2017) have shown that the geological evolution of the Abitibi and neighbouring Opatica and Pontiac subprovinces can be best explained by subduction-driven accretionary processes similar to those that operate at modern convergent plate margins.

The subduction-driven tectonic accretionary models proposed for the Abitibi subprovince have recently been challenged by several studies that exclude the operation of modern-style subduction zone processes in the Archean (Thurston et al. 2002; Bédard 2006; Bédard et al. 2013; Bédard and Harris 2014). Subduction-free models, however, cannot provide a satisfactory explanation for the presence of multiple phases of deformation, including large-scale strike-slip and thrust faults, diverse geochemical signatures, structurally-bound diverse lithotectonic assemblages, and arc-plume interactions (Benn et al. 1992; Kimura et al. 1993; Corfu 1993; Lacroix and Sawyer 1995; Jackson and Cruden 1995; Dostal and Mueller 1997; Bédard and Ludden 1997; Kerrich et al. 1998; Calvert and Ludden 1999; Sproule et al. 2002). In addition, studies of granitoid rocks in the Abitibi subprovince (Sutcliffe et al. 1993; Bédard and Ludden 1997; Chown et al. 2002) have shown that the origin of these rocks is closely related to tectonic processes and that they have subduction zone geochemical signatures that are consistent with the construction of the Abitibi subprovince by subduction-accretion processes.

Ayer et al. (2002) proposed that supracrustal belts in the Southern Volcanic Zone formed as autochthonous rather than allochthonous assemblages and they identified nine such supracrustal assemblages. These assemblages include both plume- and subduction-derived volcanic rocks, with depleted mantle $\mathrm{Nd}$ and $\mathrm{Hf}$ isotopic signatures. Autochthonous deposition of the volcanic 
864

865

866

867

868

869

870

871

872

873

874

875

876

877

878

879

880

881

882

883

884

885

886

887

888

889

890

891

892

893

rocks in the Southern Volcanic Zone, however, does not rule out the operation of plate tectonics in the Archean. For example, the Permian Siberian, Cretaceous Deccan, Karroo, and Cenozoic Basin and Range basalts were all deposited as autochthonous sequences during the operation of plate tectonics in the Phanerozoic.

The trace element patterns of the anorthosites, leucogabbros, gabbros and mafic dykes in the Doré Lake Complex and the spatially associated basalts and gabbros in the Obatogamau Formation are collectively consistent with a suprasubduction zone tectonic setting (Figs. 15-18). Similarly, rocks in other formations of the Roy Group (see Bédard et al. 2009; Leclerc et al. 2011) share the trace element patterns of igneous rocks of modern convergent plate margins. On the basis of field relationships and rock types, Chown et al. (1992) suggested that the Northern Volcanic Zone resembles juvenile volcanic island arc and back-arc systems in the western Pacific Ocean. On the basis of trace element signatures, we suggest that the cycle 1 mafic volcanic rocks in the Obatogamau Formation and the Doré Lake Complex formed in a back-arc basin. We attribute the change from tholeiitic basalt and basaltic andesites with flat to slightly LREE-enriched patterns and small negative $\mathrm{Nb}$ and $\mathrm{Ta}$ anomalies, to calc-alkaline dacites and rhyolites with strongly fractionated REE patterns and large negative $\mathrm{Nb}$, $\mathrm{Ta}$ and $\mathrm{Ti}$ anomalies, with stratigraphic height in the Roy Group (see Leclerc et al. 2011) to either the evolution of the arc from a juvenile to a mature arc or to the closure of the back-arc basin.

Field and seismic studies indicate that the boundary between the Opatica and Abitibi subprovinces marks a major tectonic break (Chown et al. 1992; Jackson et al. 1994; Calvert et al. 1995; Lacroix and Sawyer 1995; Calvert and Ludden 1999; Daigneault et al. 2002). The occurrence of anorthosite-bearing layered intrusions in the Abitibi subprovince such as the Doré Lake Complex at Chibougamau and the Bell River Complex at Matagami is restricted to its northern boundary with the Opatica subprovince (Daigneault et al. 1990; Chown et al. 1992; Mortensen 1993). On the basis of these field and geophysical observations, we suggest that the anorthosite-bearing Doré Lake and Bell River Complexes mark the closure of a back-arc oceanic basin and thus represent a Neoarchean suture zone, like many Phanerozoic ophiolites. The emplacement of syntectonic intrusions in the study area between 2705-2690 Ma (Daigneault et

al. 1990; Chown et al. 1992) marks the time of the suturing event between the Abitibi and Opatica subprovinces. 
Collectively, field, geochemical, geochronological and geophysical studies indicate that the

Abitibi subprovince is a product of complex tectonic processes that vary in space and time and that involve the development of intra-oceanic arcs, accretion of arcs and oceanic plateaus, plume and arc interactions, and suturing events (Ludden et al. 1986; Jackson et al. 1994; Calvert and Ludden 1999; Mueller et al. 1996; Dostal and Mueller 1996; Wyman et al. 2002; Ayer et al. 2002; Daigneault et al. 2002, 2004; Wyman 2013).

\section{Conclusions}

The following conclusions are drawn from this study of the Neoarchean (ca. $2728 \mathrm{Ma}$ ) Doré Lake Complex and spatially associated basalts and gabbros in the Obatogamau Formation of the Roy Group in the Chibougamau area, Abitibi subprovince:

1. Field, petrographic and SEM studies indicate that the Doré Lake Complex underwent extensive metamorphic recrystallization, resulting in the development of epidote group minerals $(40-50 \%)$ at the expense of plagioclase and chlorite (20-30\%) at the expense of mafic minerals. Although igneous cumulate textures are well preserved at many locations, almost all of the primary igneous minerals have been replaced by metamorphic counterparts. Backscatter electron images and EDS analyses indicate that plagioclase is predominantly recrystallized to anorthite and albite endmembers, erasing the record of intermediate plagioclase compositions. The replacement of albite by sericite and muscovite in strongly sheared rocks is consistent with alkaline metasomatism. Values of $\delta^{18} \mathrm{O}$ as low as $+4.8 \%$ for altered plagioclase are consistent with high-temperature hydrothermal alteration. The metamorphic alteration has mobilized many elements including $\mathrm{Cr}, \mathrm{Ni}, \mathrm{V}$, $\mathrm{Fe}, \mathrm{Li}, \mathrm{Rb}, \mathrm{Sr}, \mathrm{K}, \mathrm{Na}, \mathrm{U}$ and $\mathrm{Pb}$, leading to large variations of these elements in the anorthosites, leucogabbros, gabbros, mafic dykes and basalts.

2. Metamorphism has also disturbed the $\mathrm{Rb}-\mathrm{Sr}$ and $\mathrm{U}-\mathrm{Pb}$ isotope systems, resulting in $1935 \pm 150 \mathrm{Ma}$ and $3326 \pm 270 \mathrm{Ma}$ errochron ages, respectively. In contrast to the $\mathrm{Rb}-\mathrm{Sr}$ and $\mathrm{U}-\mathrm{Pb}$ isotope systems, the $\mathrm{Sm}-\mathrm{Nd}$ isotope system is less disturbed, yielding an errorchron age of $2624 \pm 160$ Ma that within uncertainty agrees with the 2728 Ma crystallization age of the Doré Lake Complex.

3. Major and trace element data suggest that the anorthosites and leucogabbros in the Doré Lake Complex were derived from different magma compositions than the gabbroic pods 
and mafic dykes, implying the presence of two different magmatic suites in the complex. The gabbros (layered and pods) and mafic dykes in the Doré Lake Complex are compositionally similar to the tholeiitic basalts and gabbros in the Obatogamau Formation of the Roy Group, suggesting a possible cogenetic relationship between the two. The anorthosites and leucogabbros display several different REE patterns, reflecting several different compositional batches of magmas/crystal mushes.

4. The large positive $\varepsilon N d$ values of the least altered anorthosites $(+2.8$ to +5.0$)$, leucogabbros $(+3.6$ to +3.8$)$, gabbros $(+2.6$ to +3.4$)$ and mafic dykes $(+3.0$ to +3.8$)$ are consistent with a long-term depleted mantle source for the Doré Lake Complex. The initial $\varepsilon \mathrm{Nd}$ and $\delta^{18} \mathrm{O}$ of the anorthosites (average $+6.8 \%$ ), gabbros (average $+6.8 \%$ ), and 'fresh' plagioclase (average $+6.8 \%$ ) separates are inconsistent with extensive contamination of the complex by continental crust. Similarly, the $\mathrm{Nd}(\varepsilon \mathrm{Nd}=+2.8$ to +4.0$)$ isotope and $\delta^{18} \mathrm{O}$ (average $+7.7 \%$ ) of gabbros from the Obatogamau Formation of the Roy Group rule out extensive crustal contamination. These isotopic characteristics indicate that the Doré Lake Complex and the Obatogamau Formation of the Roy Group originated in an intra-oceanic setting that was distal from older continental sources.

5. The Doré Lake Complex and spatially associated volcanic and gabbroic rocks of the Roy Group share the REE-HFSE systematics of modern arc magmas. The enrichment of LREE relative to HREE and the depletion of $\mathrm{Nb}$ and $\mathrm{Ta}$ relative to $\mathrm{La}$ and $\mathrm{Th}$ in the Doré Lake Complex are consistent with an intra-oceanic suprasubduction zone setting. On the basis of regional geological characteristics and the geochemical compositions of the rocks in the Chibougamau area, we suggest that the Doré Lake Complex formed in a back-arc basin.

6. The boundary between the Abitibi and Opatica subprovinces marks a major tectonic break. The anorthosite-bearing layered intrusions, such as the Doré Lake Complex at Chibougamau and the Bell River Complex at Matagami, are restricted to the northern boundary of the Abitibi subprovince. It is suggested that these layered intrusions and associated volcanic rocks are remnants of a back-arc oceanic crust, representing an Archean suture zone.

\section{Acknowledgements}


We thank Tuoyu Wu for drafting Fig. 1. This research is supported by NSERC grants to A. Polat and F.J. Longstaffe. David Symons reviewed the initial draft of the paper. We acknowledge reviewers Brian Windley and Derek Wyman for their constructive, incisive comments. Sharon Lackie is acknowledged for assisting SEM analyses. We would also like to thank Toby Leeper for always maintaining the mass spectrometers at the Department of Geoscience and Natural Resource Management, University of Copenhagen, in perfect running conditions and thank Toni Larsen for lab-assistance. The assistance of Andrea Prentice and Kim Law with the oxygen isotope analyses at LSIS is also very much appreciated. This is Western's Laboratory for Stable Isotope Science Contribution \#352.

\section{References}

Allard GO (1976) Doré Lake Complex and its importance to the Chibougamau geology and metallogeny. Ministère des Richesses Naturelles du Québec, DP 368.

Allard GO, Caty JL, Chown EH, Cimon J, Gobeil A, Baker D (1979) Stratigraphie et métallogénie de la région de Chibougamau. Geological Association of Canada/ Mineralogical Association of Canada meeting, Québec, Field Guide B-1, pp. 95.

Allard GO, Caty JL, Gobeil A (1985) The Archean supracrustal rocks of the Chibougamau area. In: Ayres LD, Thurston PC, Card KD, Weber W. (Eds.), Evolution of Archean Supracrustal Sequences. Geological Association of Canada Special Paper 28: 55-63.

Ashwal LD (1993) Anorthosites. Minerals and Rocks Series 21. Springer-Verlag, Berlin, 422 pp.

Ashwal LD (2010) The temporality of anorthosites. The Canadian Mineralogist 48: 711-728.

Ashwal LD, Morrison DA, Phinney WC, Wood J (1983) Origin of Archean anorthosites: evidence from the Bad Vermilion Lake Anorthosite Complex, Ontario. Contributions to Mineralogy and Petrology 82: 259-273.

Ayer J, Amelin Y, Corfu F, Kamo S, Ketchum J, Kwok K, Trowell N (2002) Evolution of the southern Abitibi belt based on U-Pb geochronology: autochthonous volcanic construction followed by plutonism, regional deformation and sedimentation. Precambrian Research 115: 63-95.

Backeberg NR, Rowe CD, van Hinsberg VJ, Bellefroid EJ (2014) Structural and metamorphic evidence for Mesoarchaean subduction in the Finlayson Lake greenstone belt, Superior Province, Ontario. Precambrian Research 249: 100-114. 
Bédard, JH 2006. A catalytic delamination-driven model for coupled genesis of Archaean crust and sub-continental lithospheric mantle. Geochimica et Cosmochimica Acta 70, 1188-1214.

Bédard JH, Harris LB (2014) Neoarchean disaggregation and reassembly of the Superior craton. Geology 42: 951-954.

Bédard JH, Harris LB, Thurston PC (2013) The hunting of the snArc. Precambrian Research 229: $20-48$.

Bédard JH, Leclerc F, Harris LB, Goulet N (2009) Intra-sill magmatic evolution in the Cumming Complex, Abitibi greenstone belt: Tholeiitic to calc-alkaline magmatism recorded in an Archean subvolcanic conduit system. Lithos 111: 47-71.

Bédard, LP, Ludden JN (1997) Nd-isotope evolution of Archean plutonic rocks in southeastern Superior Province. Canadian Journal of Earth Sciences 34: 286-298.

Bell CK (1978) Geology, Wekusko Lake map-area, Manitoba. Geological Survey of Canada, Memoir 384, pp. 84.

Benn K, Sawyer EW, Bouchez JL (1992) Orogen parallel and transpressive shearing in the Opatica belt, Quebec: implications for the structure of the Abitibi Subprovince. Canadian Journal of Earth Sciences 29: 2429-2444.

Bleeker W, Parrish RR (1996) Stratigraphy and U-Pb zircon geochronology of Kidd Creek: implications for the formation of giant volcanogenic massive sulphide deposits and the tectonic history of the Abitibi greenstone belt. Canadian Journal of Earth Sciences 33: $1213-1231$.

Borthwick J, Harmon RS (1982) A note regarding ClF3 as an alternative to BrF5 for oxygen isotope analysis. Geochimica et Cosmochimica Acta 46: 1665-1668.

Bosch D, Jamais M, Boudier F, Nicolas A, Dautria JM, Agrinier P (2004) Deep and hightemperature hydrothermal circulation in the Oman ophiolite-petrological and isotopic evidence. Journal of Petrology 45: 1181-1208.

Burnham, OM, Hechler JH, Semenyna L, Schweyer J (2002) Mineralogical controls on the determination of trace elements following mixed acid dissolution. In: Summary of Field Work and Other Activities 2002. Ontario Geological Survey Open File Report 6100, p. 36-1 to 3612.

Burnham OM, Schweyer J (2004) Trace element analysis of geological samples by ICP-MS at the Geoscience Laboratories: Revised capabilities due to improvements to instrumentation. In: 
Summary of Field Work and Other Activities 2004. Ontario Geological Survey Open File 1018 Report 6145, p. 54-1 to 54-20.

1019 Calvert AJ, Ludden JN (1999) Archean continental assembly in the southeastern Superior 1020 Province of Canada. Tectonics 18: 412-429.

1021 Calvert AJ, Sawyer EW, Davis WJ, Ludden JN (1995) Archaean subduction inferred from 1022 seismic images of a mantle suture in the Superior Province. Nature 375: 670-674.

1023 Camiré E, Burg JP (1992) Late Archean thrusting in the NW Pontiac Subprovince, Canadian 1024 Shield. Precambrian Research 61: 51-66.

1025

Card KD (1990) A review of the Superior Province of the Canadian shield, a product of Archean 1026 accretion: Precambrian Research 48: 99-156.

1027 Card KD, Ciesielski A (1986) Subdivisions of the Superior Province of the Canadian Shield. 1028 Geoscience Canada 13: 5-13.

1029

Chown, EH, Daigneault R, Mueller W, Mortensen JK (1992) Tectonic evolution of the Northern Volcanic Zone, Abitibi Belt, Quebec. Canadian Journal of Earth Sciences 29: 2211-2225.

Chown, EH, Harrap R, Moukhsil A (2002) The role of granitic intrusion in the evolution of the 1033 1034 1035 1036 Abitibi belt, Canada. Precambrian Research 115: 291-310.

Clayton RN, Mayeda TK (1963) The use of bromine pentafluoride in the extraction of oxygen from oxides and silicates for isotopic analysis. Geochimica et Cosmochimica Acta 27: 43-52. Corfu F (1993) The evolution of the southern Abitibi greenstone belt in the light of precise of precise U-Pb geochronology. Economic Geology 88: 1323-1340.

Corkery MT (1985) Geology of the Lower Nelson River Project area, Manitoba; Manitoba Energy and Mines, Geological Services/Mines Branch, Geological Report GR82-1, pp. 66.

Daigneault R, St-Julien P, Allard GO (1990) Tectonic evolution of the northeast portion of the Abitibi greenstone belt, Chibougamau area, Quebec. Canadian Journal of Earth Sciences 27: 1714-1736.

Daigneault R, Mueller WU, Chown EH (2002) Oblique Archean subduction: accretion and exhumation of an oceanic arc during dextral transpression, Southern Volcanic Zone, Abitibi Subprovince Canada. Precambrian Research 115: 261-290.

Daigneault R, Mueller WU, Chown EH (2004) Abitibi greenstone belt plate tectonics: the diachronous history of arc development, accretion and collision. In: Eriksson PG, Altermann 
W, Nelson DR, Mueller WU, Catuneanu, O. (Eds.), The Precambrian Earth: Tempos and Events, Developments in Precambrian Geology, Elsevier, Amsterdam, pp. 88-103.

Davis DW (1992) U-Pb dating of detrital zircon in sediments in the Pontiac and Abitibi subprovinces; preliminary results. Lithoprobe Report 19, pp. 33-35.

Davis WJ, Lacroix S, Gariépy C, Machado N (2000) Geochronology and isotope geochemistry of plutonic rocks from the central Abitibi subprovince: significance to the internal subdivition and plutono-tectonic evolution of the Abitibi belt. Canadian Journal of Earth Sciences 37: 117-133.

Davis DW, Sutcliffe RH, Trowell NF (1988) Geochronological constraints on the tectonic evolution of a late Archean greenstone belt, Wabigoon subprovince, northwest Ontario. Precambrian Research 39: 171-191.

Desrochers JP, Hubert C, Ludden JN, Pilote P (1993) Accretion of Archean oceanic plateau fragments in the Abitibi, Greenstone belt, Canada. Geology 21: 451-454.

Devaney JR, Williams HR (1989) Evolution of an Archean subprovince boundary: a sedimentological and structural study of part of the Wabigoon-Quetico boundary in northern Ontario. Canadian Journal of Earth Sciences 26: 1013-1026.

Dimroth E, Imreh L, Rocheleau M, Goulet N (1982) Evolution of the south-central part of the Archean Abitibi belt, Quebec, Part 1: Stratigraphy and paleogeographic model. Canadian Journal of Earth Sciences 19: 1729-1758.

Dimroth E, Imreh L, Rocheleau M, Goulet N (1983) Evolution of the south-central part of the Archean Abitibi Belt, Quebec. Part II: tectonic evolution and geomechanical model. Canadian Journal of Earth Sciences 20: 1355-1373.

Dimroth E, Rocheleau M, Mueller W (1984) Paleogeography, isostasy and crustal evolution of the Archean Abitibi Belt: a comparison between the Rouyn-Noranda and the ChibougamauChapais areas. In: Guha J, Chown EH (Eds.), Chibougamau stratigraphy and mineralization. The Canadian Institute of Mining and Metallurgy, Special Volume 34, pp. 73-91.

Dimroth E, Mueller W, Daigneault R, Brisson H, Poitras A, Rocheleau M (1986) Diaprism during regional compression: the structural pattern in the Chibougamau region of the Archean Abitibi Belt, Quebec. Geologische Rundschau 74: 11-32. 
1076

1077

1078

1079

1080

1081

1082

1083

1084

1085

1086

1087

1088

1089

1090

1091

1092

1093

1094

1095

1096

1097

1098

1099

1100

1101

1102

1103

1104

1105

Dostal J, Mueller W (1996) An Archean oceanic felsic dyke swarm in a nascent arc: the Hunter Mine Group, Abitibi Greenstone Belt, Canada. Journal of Volcanology and Geothermal Research 72: 37-57.

Dostal J, Mueller W (1997) Komatiite flooding of a rifted Archean rhyolite complex: geochemical signature and tectonic significance of the Stoughton-Roquemaure Group, Abitibi greenstone belt, Canada. Journal of Geology 105: 545-563.

Dupré B, Chauvel C, Arndt NT (1984) Pb and Nd isotopic study of two Archean komatiites flows from Alexo, Ontario. Geochimica Cosmochimica et Acta 48: 2371-2383.

Edgar AD, Sweeny JM (1991) The Geochemistry, Origin and Economic Potential of the Platinum Group Element Bearing Rocks of the Lac des Iles Complex, Northwestern Ontario, Ontario Geoscience Research Grant Program, Grant No. 286; Ontario Geological Survey, Open File Report 5746, pp. 87.

Eiler JM (2001) Oxygen isotope variations in basaltic lavas and upper mantle rocks. In: Valley JW, Cole DR (Eds.), Stable Isotope Geochemistry. Reviews in Mineralogy and Geochemistry, 43, Mineralogical Society of America, Washington, pp. 319-364.

Frei R, Polat A (2013) Chromium isotope fractionation during oxidative weathering implications from the study of a Paleoproterozoic (ca. $1.9 \mathrm{Ga}$ ) paleosol, Schreiber Beach, Ontario, Canada. Precambrian Research 224: 434-453.

Frieman, BM, Kuiper YD, Kelly NM, Monecke T, Kylander-Clark A (2017) Constraints on the geodynamic evolution of the southern Superior Province: U-Pb LA-ICP-MS analysis of detrital zircon in successor basins of the Archean Abitibi and Pontiac subprovinces of Ontario and Quebec, Canada. Precambrian Research 292: 398-416.

Gilbert HP (2007) Stratigraphic investigations in the Bird River greenstone belt, Manitoba (part of NTS 52L5, 6). In Report of Activities 2007, Manitoba Science, Technology, Energy and Mines, Manitoba Geological Survey, pp. 129-143.

Goodwin AM (1996) Principles of Precambrian Geology. Academic Press, Toronto, pp. 327.

Hartlaub RP, Böhm CO, Kuiper YD, Bowerman MS, Heaman LM (2004) Archean and Paleoproterozoic geology of the northwestern Split Lake Block, Superior Province, Manitoba (parts of NTS 54D4, 5, 6 and 64A1). In: Report of Activities 2004, Manitoba Industry, Economic Development and Mines, Manitoba Geological Survey, pp. 187-194. 
Hawkesworth CJ, Gallanger K, Hergt JM, McDermott F (1993) Mantle and slab contributions in arc magmas. Annual Reviews of Earth and Planetary Science 21: 175-204.

Henry P, Stevenson RK, Gariépy C (1998) Late Archaean mantle composition and crustal growth in the Western Superior Province of Canada: neodymium and lead isotopic evidence from the Wawa, Quetico and Wabigoon subprovinces. Geochimica et Cosmochimica Acta 62: 143-157.

Hoffmann JE, Svahnberg H, Piazolo S, Scherstén A, Münker C (2012) The geodynamic evolution of Mesoarchean anorthosite complexes inferred from the Naajat Kuuat Complex, southern West Greenland. Precambrian Research 196-197: 149-170.

Hollings P, Wyman D (1999) Trace element and Sm-Nd systematics of volcanic and intrusive rocks from the $3 \mathrm{Ga}$ Lumby Lake greenstone belt, Superior Province: evidence for Archean plume-arc interaction. Lithos 46: 189-213.

Hollings P, Stott G, Wyman D (2000) Trace element geochemistry of the Meen-Dempster belt, Uchi Subprovince, Canada; back-arc development on the margins of an Archean protocontinent. Canadian Journal of Earth Sciences 37: 1021-1038.

Jackson SL, Cruden AR (1995) Formation of the Abitibi greenstone belt by arc-trench migration. Geology 23: 471-474.

Jackson SL, Fyon JA (1991) The Western Abitibi Subprovince in Ontario. In: Thurston PC, Williams HR, Sutcliffe RH, Stott G (Eds.), Geology of Ontario, Ontario Geological Survey, Special vol. 4/1, pp. 405-482.

Jackson SL, Fyon JA, Corfu F (1994) Review of Archean supracrustal assemblages of the southern Abitibi greenstone belt in Ontario, Canada: products of microplate interaction within a large-scale plate-tectonic setting. Precambrian Research 65: 183-205.

Kerrich R, Wyman D, Fan J, Bleeker W (1998) Boninite series: low Ti-tholeiite association from 2.7 Ga Abitibi greenstone belt. Earth Planetary Science Letters 164: 303-316.

Kimura G, Ludden JN, Desrochers JP, Hori R (1993) A model of ocean- crust accretion for the Superior Province, Canada. Lithos 30: 337-355.

Krogh TE (1982) Improved accuracy of U-Pb ages by the creation of more concordant systems using air abrasion technique. Geochemica et Cosmochemica Acta 46: 637-649. 
Lacroix S, Sawyer EW (1995) An Archean fold - thrust belt in the northwestern Abitibi Greenstone Belt: structural and seismic evidence. Canadian Journal of Earth Sciences 32: $97-112$.

Lacroix S, Sawyer EW, Chown EH (1998) Pluton emplacement within an extensional transfer zone during dextral strike-slip faulting: an example from the late Archean Abitibi Greenstone Belt. Journal of Structural Geology 20: 43-59.

Lahaye Y, Arndt N (1996) Alteration of a komatiite flow from Alexo, Ontario, Canada. Journal of Petrology 37: 1261-1284.

Lahaye Y, Arndt N, Byerly G, Chauvel C, Fourcade S, Gruau G (1995) The influence of alteration on the trace-element and $\mathrm{Nd}$ isotopic compositions of komatiites. Chemical Geology 126: 43-64.

Langford FF, Morin MA (1976) The development of the Superior Province of Northwestern Ontario by merging island arcs. American Journal of Science 276: 1023-1034.

Leclerc F, Bédard JH, Harris LB, McNicoll VJ, Goulet N, Roy P, Houle P (2011) Tholeiitic to calc-alkaline cyclic volcanism in the Roy Group, Chibougamau area, Abitibi Greenstone Belt - revised stratigraphy and implications for VHMS exploration. Canadian Journal of Earth Sciences 48: 661-694.

Lesher CM, Stone WE, Arndt NT (1997) Nd isotope geochemistry of komatiites in the AbitibiPontiac greenstone belt. Geological Association of Canada-Mineralogical Association of Canada Annual Meeting, Ottawa, Program with Abstracts, v. 22, p. A88.

Lodge RWD, Gibson HL, Stott GM, Franklin JM, Hudak GJ (2015) Geodynamic setting, crustal architecture, and VMS metallogeny of ca. 2720 Ma greenstone belt assemblages of the northern Wawa subprovince, Superior Province. Canadian Journal of Earth Sciences 52: 196-214.

Ludden J, Gelienas L, Trudel P (1982) Archean metavolcanics from the Rouyn-Noranda district, Abitibi greenstone belt, Quebec; 2. Mobility of trace elements and petrogenetic constraints, Canadian Journal of Earth Science 19: 2276-2287.

Ludden JN, Hubert C (1986) Geologic evolution of the late Archean Abitibi greenstone belt of Canada. Geology 14: 707-711.

Ludden JN, Francis D, Allard G (1984) The geochemistry and evolution of the volcanic rocks of the Chibougamau region of the Abitibi metavolcanic belt. In: Guha, J, Chown EH (Eds.), 
Chibougamau-Stratigraphy and Mineralization. Canadian Institute of Mining and Metallurgy Special Volume 34, pp. 20-34.

Ludden JN, Hubert C, Gariépy C (1986) The tectonic evolution of the Abitibi greenstone belt of Canada: Geological Magazine 123: 153-166.

Ludwig KR (2003) ISOPLOT 3.75: A Geochronological Toolkit for Microsoft Excel. Berkeley:

Machado N, Brooks C, Hart SR (1986) Determination of initial ${ }^{87} \mathrm{Sr} /{ }^{86} \mathrm{Sr}$ and ${ }^{143} \mathrm{Nd} /{ }^{144} \mathrm{Nd}$ in primary minerals from mafic and ultramafic rocks: Experimental procedure and implications for the isotopic characteristics of the Archean mantle under the Abitibi greenstone belt. Canada. Geochimica et Cosmochimica Acta 50: 2335-2348.

Maier WD, Barnes S-J, Pellet T (1996) The economic significance of the Bell River Complex, Abitibi subprovince, Quebec. Canadian Journal of Earth Sciences 33:967-980.

Manning C.E., Weston P.E., Mahon K.I. (1996) Rapid high-temperature metamorphism of East Pacific Rise gabbros from Hess Deep. Earth and Planetary Science Letters 144: 123-132.

Morrison DA, Davis DW, Wooden JL, Bogard DD, Maczuga DE, Phinney WC, Ashwal LD (1985) Age of the Mulcahy Lake intrusion, northwest Ontario, and implications for the evolution of greenstone-granite terrains. Earth and Planetary Sciences Letters 73: 306-316.

Mortensen JK (1993) U-Pb geochronology of the eastern Abitibi subprovince. Part 1: Chibougamau-Matagami-Joutel region. Canadian Journal of Earth Sciences 30: 11-28.

Moyen JF, van Hunen J (2012) Short-term episodicity of Archean plate tectonics. Geology 40: $451-454$.

Mueller WU (1991) Volcanism and related slope to shallow marine volcaniclastic sedimentation: an Archean example, Chibougamau, Quebec, Canada. Precambrian Research 49: 1-22.

Mueller W, Chown EH, Sharma KNM, Tait L, Rocheleau M (1989) Palegeographic and paleotectonic evolution of a basement controlled Archean supracrustal sequence, Chibougamau, Québec. Journal of Geology 97: 399-420.

Mueller WU, Corcoran PL (1998) Late-orogenic basins in the Archean Superior Province, Canada: characteristics and inferences. Sedimentary Geology 120: 177-203.

Mueller W, Daigneault R, Mortensen J, Chown EH (1996) Archean terrane docking: upper crust collision tectonics, Abitibi Greenstone Belt, Quebec, Canada. Tectonophysics 265: 127-150. 
Mueller W, Dimroth E (1984) Sedimentology and depositional history of the Blondeau and Chebisttuan Formations in the Waconichi syncline, Chibougamau, Quebec. In: Guha, J, Chown EH (Eds.), Chibougamau, stratigraphy and mineralization. Canadian Institute of Mining and Metallurgy, Special Volume 34, pp. 137-152.

Murphy JB (2007) Arc magmatism II: Geochemical and isotopic characteristics. Geoscience Canada 34: 7-35.

Myers JS (1976) Granitoid sheets, thrusting, and Archean crustal thickening in West Greenland. Geology 4: 265-268.

Myers JS (1985) Stratigraphy and structure of the Fiskenæsset Complex, southern West Greenland. Grønlands Geologiske Undersøgelse Bulletin 150, pp. 72.

Ordóñez-Calderón JC, Polat A, Fryer BJ, Gagnon JE (2011) Field and geochemical characteristics of Mesoarchean to Neoarchean volcanic rocks in the Storø greenstone belt, SW Greenland: Evidence for accretion of intra-oceanic volcanic arcs. Precambrian Research 184: 24-42.

Ordóñez-Calderón JC, Polat A, Fryer B, JE Gagnon JE, Raith JG Appel PWU (2008) Evidence for HFSE and REE mobility during calc-silicate metasomatism, Mesoarchean ( $3075 \mathrm{Ma})$ Ivisaartoq greenstone belt, southern West Greenland. Precambrian Research 161: 317-340.

Peck DC, Halden NM, Jobin-Bevans S, Cameron HDM, Theyer P (1999) Summary of metallogenetic and petrogenetic features of Archean anorthosites and associated mafic and ultramafic rocks in the Superior Province, Manitoba (parts of NTS 63I, 63J, 63P and 64A). In: Report of Activities, 1999, Manitoba Industry, Trade and Mines, Geological Services, pp. 94-96.

Peck DC, Messing C, Halden NM, Chandler C (1998) New insights into the petrogenesis of the Pipestone Lake anorthosite complex and its Ti-V-Fe oxide deposits (parts of NTS 63I/5 and I/12). In: Manitoba Energy and Mines, Geological Services, Report of Activities, 1998, pp. 127-134.

Pellet T, Barnes SJ (1991) The Bell River intrusion, Matagami area, Quebec. Geological Association of Canada and Mineralogical Association of Canada Program with Abstracts, 16: A96. 
1225

1226

1227

1228

1229

1230

1231

1232

1233

1234

1235

1236

1237

1238

1239

1240

1241

1242

1243

1244

1245

1246

1247

1248

1249

1250

1251

1252

1253

1254

Percival JA, Sanborn-Barrie M, Stott GM, Helmstaedt H, Skulski T, White DJ (2006) Tectonic evolution of the Western Superior Province from NATMAP and LITHOPROBE studies: Canadian Journal of Earth Sciences 43: 1085-1117.

Percival JA, Skulski T, Sanborn-Barrie M, Stott GM, Leclair AD, Corkery MT, Boily M (2012) Geology and Tectonic Evolution of the Superior Province, Canada. In: Percival, JA, Cook FA, Clowes RM, (Eds.), Tectonic Styles in Canada: The LITHOPROBE Perspective. Geological Association of Canada Special Paper 49, pp. 321-378.

Polat A, Hofmann AW (2003) Alteration and geochemical patterns in the 3.7-3.8 Ga Isua greenstone belt, West Greenland. Precambrian Research 126: 197-218.

Polat A, Kerrich R (2001) Geodynamic processes, continental growth, and mantle evolution recorded in late Archean greenstone belts of the southern Superior Province, Canada. Precambrian Research 112: 5-25.

Polat A, Kerrich R (2006) Reading the Geochemical Fingerprints of Archean Hot Subduction Volcanic Rocks: Evidence for Accretion and Crustal Recycling in a Mobile Tectonic Regime. In: Benn, K, Mareschal, JC, Condie KC (Eds.), Archean Geodynamics and Environments, American Geophysical Union Geophysical Monograph Series 164: 189-213.

Polat A, Kerrich R, Wyman DA (1998) The late Archean Schreiber-Hemlo and White RiverDayohessarah greenstone belts, Superior Province: Collages of oceanic plateaus, Oceanic island arcs, and subduction-accretion complexes. Tectonophysics 289: 295-326.

Polat A, Kokfelt T, Burke KC, Kusky T, Bradley D, Dziggel A, Kolb J (2016) Lithological, structural, and geochemical characteristics of the Mesoarchean Târtoq greenstone belt, South-West Greenland, and the Chugach-Prince William accretionary complex, southern Alaska: Evidence for uniformitarian plate-tectonic processes. Canadian Journal of Earth Sciences 53: 1336-1371.

Polat A, Longstaffe FJ (2014) A juvenile oceanic island arc origin for the Archean (ca. 2.97 Ga) Fiskenæsset Anorthosite Complex, southwestern Greenland: Evidence from oxygen isotopes. Earth and Planetary Science Letters 396: 252-266.

Polat A, Longstaffe F, Weisener C, Fryer B, Frei R, Kerrich R (2012) Extreme element mobility during transformation of Neoarchean (ca. $2.7 \mathrm{Ga}$ ) pillow basalts to a Paleoproterozoic (ca. 1.9 Ga) paleosol, Schreiber Beach, Ontario, Canada. Chemical Geology 326-327: 145-173. 
1255

1256

1257

1258

1259

1260

1261

1262

1263

1264

1265

1266

1267

1268

1269

1270

1271

1272

1273

1274

1275

1276

1277

1278

1279

1280

1281

1282

1283

1284

1285

Polat A, Wang L, Appel PWU (2015) A review of structural patterns and melting processes in the Archean craton of West Greenland: Evidence for crustal growth at convergent plate margins as opposed to non-uniformitarian models. Tectonophysics 662: 67-94.

Poulsen KH, Borradaile GJ, Kehlenbeck MM (1980) An inverted Archean succession at Rainy Lake, Ontario. Canadian Journal of Earth Sciences 17: 1358-1369.

Ross PS, Bédard JH (2009) Magmatic affinity of modern and ancient subalkaline volcanic rocks determined from trace element discriminant diagrams. Canadian Journal of Earth Sciences 46: 823-839.

Saunders AD, Norry MJ, Tarney J (1991) Fluid influence on the trace element compositions of subduction zone magmas. Philosophical Transactions of Royal Society London A, 335: 377392.

Sawyer EW, Benn K (1993) Structure of the high-grade Opatica belt and adjacent low-grade Abitibi Subprovince: An Archean mountain front. Journal of Structural Geology 15: 14431458.

Schweyer J (2006) QA/QC: Summary of 2005-2006 quality control data at the Geoscience Laboratories. In: Summary of Field Work and Other Activities 2006. Ontario Geological Survey Open File Report 6192, p.40-1 to 40-4.

Simmons EC and Hanson GN (1980) Geochemistry of the shawmere anorthosite complex, kapuskasing structural zone, Ontario. Precambrian Research 1: 43-71.

Sleep NH (1992) Archean plate tectonics: what can be learned from continental geology? Canadian Journal of Earth Sciences 29: 2066-2071.

Sproule RA, Lesher CM, Ayer JA, Thurston PC, Herzberg CT (2002) Spatial and temporal variations in the geochemistry of komatiites and komatiitic basalts in the Abitibi greenstone belt. Precambrian Research 115: 153-186.

Staudigel H (2003) Hydrothermal alteration processes in the oceanic crust. Treatise on Geochemistry, Vol. 3. Elsevier, pp. 511-535.

Stott GM (1997) The Superior Province, Canada. In: de Wit MJ, Ashwal LD (Eds.), Greenstone Belts. Oxford Monographs Geology and Geophysics, Volume 35, Oxford, Clarendon, pp. 480-507.

Sun SS, McDonough WF (1989) Chemical and isotopic systematics of oceanic basalts: implications for mantle composition and processes. In: Saunders AD, Norry MJ (Eds.), 
Magmatism in the Ocean Basins. Geological Society of London Special Publication 42, pp. 313-345.

Sutcliffe HR, Barrie, CT, Burrows DR, Beakhosue GP (1993) Plutonism in the southern Abitibi subprovince: A tectonic and petrogenetic framework. Economic Geology 88: 1359-1375.

Taner MF, Ercit TS, Gault RA (1998) Vanadium-bearing magnetite from the Matagami and Chibougamau mining districts, Abitibi, Québec, Canada. Exploration and Mining Geology 7: 299-311.

Taylor SR, McLennan SM (1985) The Continental Crust: Its Composition and Evolution, Blackwell, Oxford, pp. 312.

Thurston PC (2002) Autochthonous development of Superior Province greenstone belts? Precambrian Research 115: 11-36.

Todt W, Cliff RA, Hanser A, Hofmann AW (1993) Re-calibration of NBS lead standards using ${ }^{202} \mathrm{~Pb}+{ }^{205} \mathrm{~Pb}$ double spike. Terra Abstract 5, 396.

Vervoort JD, White WM, Thorpe RI (1994) Neodymium and lead isotope ratios of the Abitibi greenstone belt: New evidence for early differentiation of the Earth. Earth and Planetary Science Letters 128: 215-229.

Williams HR (1990) Subprovince accretion tectonics in south-central Superior Province. Canadian Journal of Earth Sciences 27: 570-581.

Williams HR, Stott GM, Thurston PC, Sutcliffe RH, Bennett G., Easton RM, Armstrong, DK (1991) Tectonic evolution of Ontario: Summary and synthesis. In: Thurston, PC, Williams HR, Sutcliffe RH, Stott G. (Eds.), Geology of Ontario. Ontario Geological Survey, Special Vol. 4, Part 2, 1255-1332.

Windley BF, Garde AA (2009) Arc-generated blocks with crustal sections in the North Atlantic craton of West Greenland: new mechanism of crustal growth in the Archean with modern analogues. Earth-Science Reviews 93:1-30.

Wu T, Polat A, Frei R, Fryer BJ, Yang K, Kusky T (2016) Geochemistry, Nd, Pb and Sr isotope systematics, and $\mathrm{U}-\mathrm{Pb}$ zircon ages of the Neoarchean Bad Vermilion Lake Greenstone Belt and spatially associated granitic rocks, Western Superior Province, Canada. Precambrian Research 258: 21-51.

Wyman DA (1999) A 2.7 Ga depleted tholeiite suite: evidence of plume-arc interaction in the Abitibi Greenstone Belt, Canada. Precambrian Research 97: 27-42. 
1317 Wyman DA (2013) A critical assessment of Neoarchean "plume only" geodynamics: Evidence 1318 from the Superior Province. Precambrian Research 229: 3-19.

1319 Wyman DA, Kerrich R, Polat A (2002) Assembly of Archean cratonic mantle lithosphere and 1320 crust: plume-arc interaction in the Abitibi-Wawa subduction-accretion complex. Precambrian 1321 Research 115: 37-62.

1322 Yang XM, Gilbert HP (2014) Mineral chemistry of chromite in the Mayville intrusion: evidence 1323 for petrogenesis and linkage to the Bird River sill in the Neoarchean Bird River greenstone 1324 1325 1326 1327 1328 1329

Fig. 1. (a) Simplified tectonic map of the Superior Province (modified from Percival et al. 2012). A: Ashuanipi; B: Bienville; DH: Douglas Harbour; E: Eastmain; ERB: English River Belt; G: Goudalie; HBT: Hudson Bay Terrane; ILD: Island Lake Domain; KU: Kapuskasing Uplift; LG: La Grande; LM: Lac Minto; MRVT: Minnesota River Valley Terrane; MT: Marmion Terrane; NCT: North Caribou Terrane; O: Opatica; Op: Opinaca; OSD: Oxford-Stull Domain; PB: Pontiac Belt; Q: Qalluviartuuq; QB: Quetico Belt; T: Tikkerutuk; U: Utsalik; UD: Uchi Domain; WAT: Wawa-Abitibi Terrane; WRT: Winnipeg River Terrane; WWT: Western Wabigoon Terrane.

Fig. 2. Simplified geological map of the Chibougamau area (modified from Leclerc et al. 2011). 
1348 Fig. 3. Former (Daigneault and Allard 1990) and revised (Leclerc et al. 2011) stratigraphy of the 1349 Chibougamau area (modified from Leclerc et al. 2011). Fm: Formation; Mb: Member; Com: 1350 Complex.

1351

1352 Fig. 4. Field photographs of anorthosites (a-d) and leucogabbros (e-f) of the Doré Lake 1353 Complex, displaying cumulates of plagioclase. Photographs (d) and (e) represent variably 1354 brecciated anorthosite and leucogabbro outcrops, respectively. Photograph (f) is from the Doré 1355 Lake Complex and Roy Group contact characterized by intense deformation.

Fig. 5. Field photographs of leucogabbro (a), gabbro (b-d) and mafic dykes (e-f) in the Doré 1358 Lake Complex.

1359 Fig. 6. Field photographs of the Doré Lake Complex (a) and the Roy Group (b-f). (a) Pods of 1360 gabbro intruding the leucogabbro. (b) Vesicular basalt (Obatogamau Formation) with amygdules. 1361 (c) Iron-rich sedimentary rocks in tectonic contact with gabbros. (d) Gabbro (Cumming 1362 Complex?) and mylonitized supracrustal rocks. Contact is defined by a thrust fault. (e) Deformed 1363 gabbro within a serpentinized ultramafic rock of the Cumming Complex. (f) Gabbro and 1364 ultramafic outcrop in the Cumming Complex.

Fig. 7. Photomicrographs of the anorthosites, leucogabbros, gabbros and mafic dykes in the Doré 1367 Lake Complex, displaying relict igneous textures. None of the primary minerals are preserved. 1368 pl: plagioclase; ch: chlorite; qz: quartz; se: sericite; r-pl: replaced plagioclase; r-py: replaced 1369 pyroxene; ep: epidote group minerals.

1371 Fig. 8. Photomicrographs of the anorthosites, leucogabbros, gabbros and mafic dykes in the Doré 1372 Lake Complex, displaying intense metasomatic and/or hydrothermal alteration. None of the 1373 primary minerals are preserved. pl: plagioclase; ch: chlorite; r-pl: replaced plagioclase; ep: 1374 epidote group minerals; se: sericite.

1376 Fig. 9. Scanning electron microscope (SEM) backscatter electron (BSE) images showing the 1377 petrographic characteristics of the anorthosites (a-d) and leucogabbro (e-f). ab: albite; an: 
1378

1379

1380

1381

1382

1383

1384

1385

1386

1387

1388

1389

1390

1391

1392

1393

1394

1395

1396

1397

1398

1399

1400

1401

1402

1403

1404

1405

1406

1407

1408

anorthite; qz: quartz; ch: chlorite; ti: titanite; rt: rutile; ep: epidote group minerals; ca: calcite; se: sericite; ms: muscovite.

Fig. 10. Scanning electron microscope (SEM) backscatter electron (BSE) images showing the petrographic characteristics of the gabbros (a-d) and mafic dykes (e-f). ac: actinolite; qz: quartz; ch: chlorite; ab: albite; an: anorthite; ti: titanite; ep: epidote group minerals.

Fig. 11. Scanning electron microscope (SEM) backscatter electron (BSE) images showing the petrographic characteristics of the metasomatized anorthosites (a-c), gabbros (d) and mafic dykes (e-f). ab: albite; an: anorthite; qz: quartz; ch: chlorite; ti: titanite; rt: rutile; ep: epidote group minerals; ca: calcite; se: sericite; ms: muscovite; mg: magnetite.

Fig. 12. Photomicrographs of the basalts (a-e) and gabbros (f) in the Obatogamau Formation of the Roy Group displaying intense metamorphic recrystallization and hydrothermal alteration. pl: plagioclase; ch: chlorite; qz: quartz; ti: titanite; ep: epidote group minerals; ca: calcite.

Fig. 13. (a-f) $\mathrm{SiO}_{2}$ (wt.\%) versus $\mathrm{Al}_{2} \mathrm{O}_{3}$ (wt.\%), $\mathrm{Fe}_{2} \mathrm{O}_{3}$ (wt.\%), $\mathrm{TiO}_{2}$ (wt.\%), $\mathrm{Sc}$ (ppm), $\mathrm{Zr}$ (ppm), and $\mathrm{Nb}(\mathrm{ppm})$ variation diagrams for the anorthosites, leucogabbros, gabbros, and mafic dykes in the Doré Lake Complex, and for the basalts and gabbros in the Obatogamau Formation (Roy Group).

Fig. 14. (a-b) $\mathrm{MgO}$ (wt.\%) versus $\mathrm{Fe}_{2} \mathrm{O}_{3}$ (wt.\%) and $\mathrm{Al}_{2} \mathrm{O}_{3}$ (wt.\%), and (c) $\mathrm{Al}_{2} \mathrm{O}_{3}$ (wt.\%) versus $\mathrm{Fe}_{2} \mathrm{O}_{3}$ (wt.\%) variation diagrams for the anorthosites, leucogabbros, gabbros, and mafic dykes in the Doré Lake Complex, and for the basalts and gabbros in the Obatogamau Formation (OF) of the Roy Group. Dash lines represent hypothetical liquid line of decent for the Doré Lake anorthosites and leucogabbros. Altered samples were excluded (see Supplementary Tables 1 and 2).

Fig. 15. N-MORB-normalized trace element diagrams for the anorthosites in the Doré Lake Complex. Normalization values are from Sun and McDonough (1989). 
1409 Fig. 16. N-MORB-normalized trace element diagrams for the leucogabbros and Group 1 gabbros

1410 in the Doré Lake Complex. Normalization values are from Sun and McDonough (1989).

1412 Fig. 17. N-MORB-normalized trace element diagrams for Group 2 gabbros (altered) and mafic

1413 dykes in the Doré Lake Complex. Normalization values are from Sun and McDonough (1989).

Fig. 18. N-MORB-normalized trace element diagrams for the basalts and gabbros in 1416 Obatogamau Formation of the Roy Group. Normalization values are from Sun and McDonough 1417 (1989).

Fig. 19. (a) ${ }^{147} \mathrm{Sm} /{ }^{144} \mathrm{Nd}$ versus ${ }^{143} \mathrm{Nd} /{ }^{144} \mathrm{Nd}$, (b) ${ }^{206} \mathrm{~Pb} /{ }^{204} \mathrm{~Pb}$ versus ${ }^{207} \mathrm{~Pb} /{ }^{204} \mathrm{~Pb}$, and (c) ${ }^{87} \mathrm{Rb} /{ }^{86} \mathrm{Sr}$ versus ${ }^{87} \mathrm{Sr} /{ }^{86} \mathrm{Sr}$ regression plots for the anorthosites and leucogabbros in the Doré Lake 1421 Complex. Gabbro and mafic dyke samples are excluded from the plots because they are not 1422 cogenetic with the anorthosite and leucogabbro samples as suggested by major and trace element 1423 plots (see Figs. 13 and 14). Reference isochrons are from Machado et al. (1986). Isoplot 3.75 1424 (Ludwig 2003) was used to generate the regression plots.

Fig. 20. (a) Age $(\mathrm{Ga})$ versus $\varepsilon_{\mathrm{Nd}}(\mathrm{t})$ and (b) ${ }^{147} \mathrm{Sm} /{ }^{144} \mathrm{Nd}$ versus $\varepsilon_{\mathrm{Nd}}(\mathrm{t})$ for the Doré Lake Complex 1427 (modified from Henry et al., 1998). Altered anorthosite samples are excluded. CC: continental 1428 crust; A: diorite to granodiorite; B: intermediate to felsic rocks; C: basalts. AN: anorthosite; LG: 1429 leucogabbro: GB: gabbro; MD: mafic dyke; OF-GB: Obatogamau Formation gabbro; 1430 GRANITOIDS data from Bédard and Ludden (1997); VER data (basalt, basaltic andesite, 1431 rhyolite, tonalite-trondhjemite) from Vervoort et al. (1994); DUP data (komatiites) from Dupré et 1432 al. (1984); LAH: Data (komatiite) from Lahaye et al. (1995). 
Fig. 1

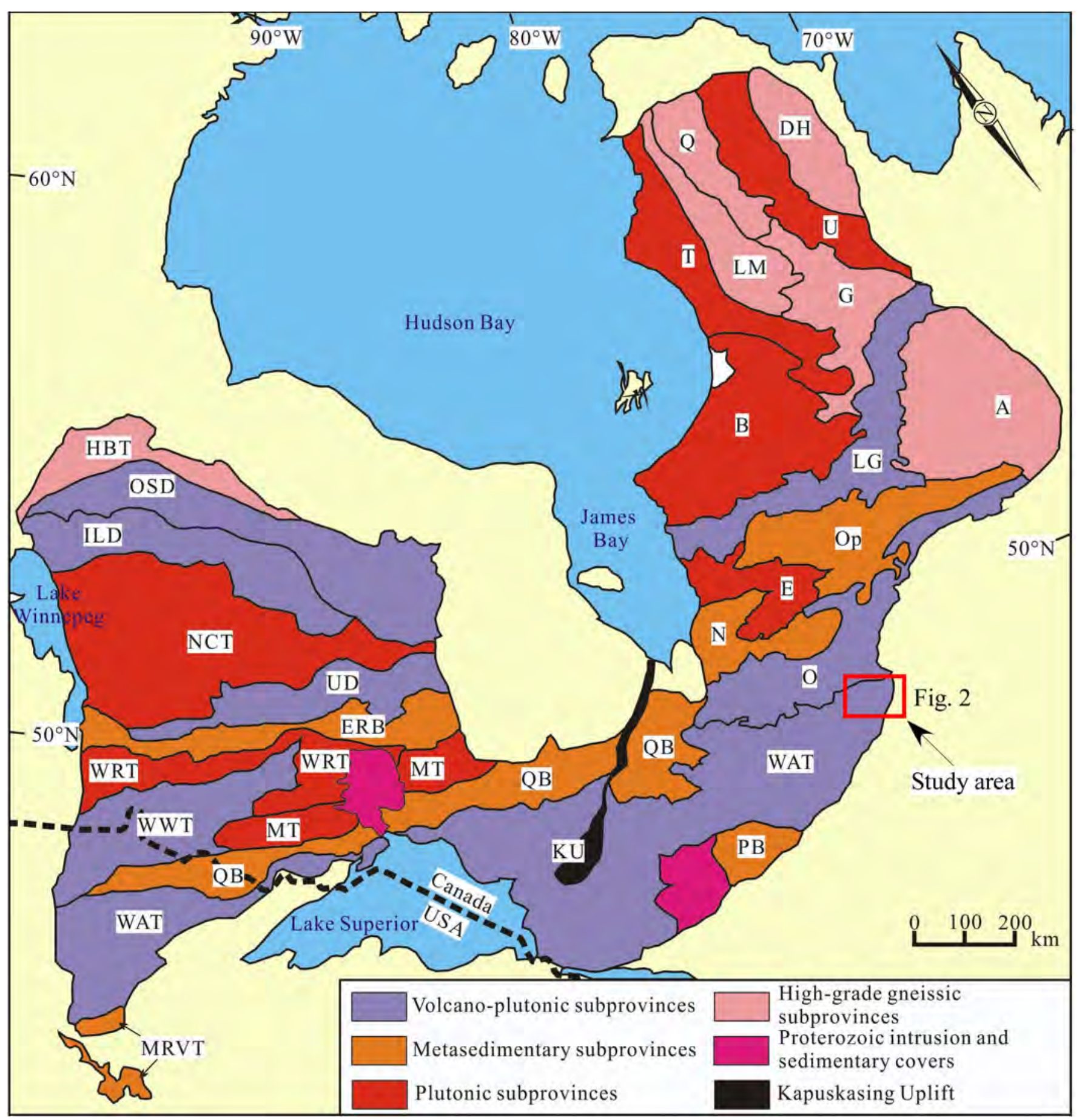


Fig. 2

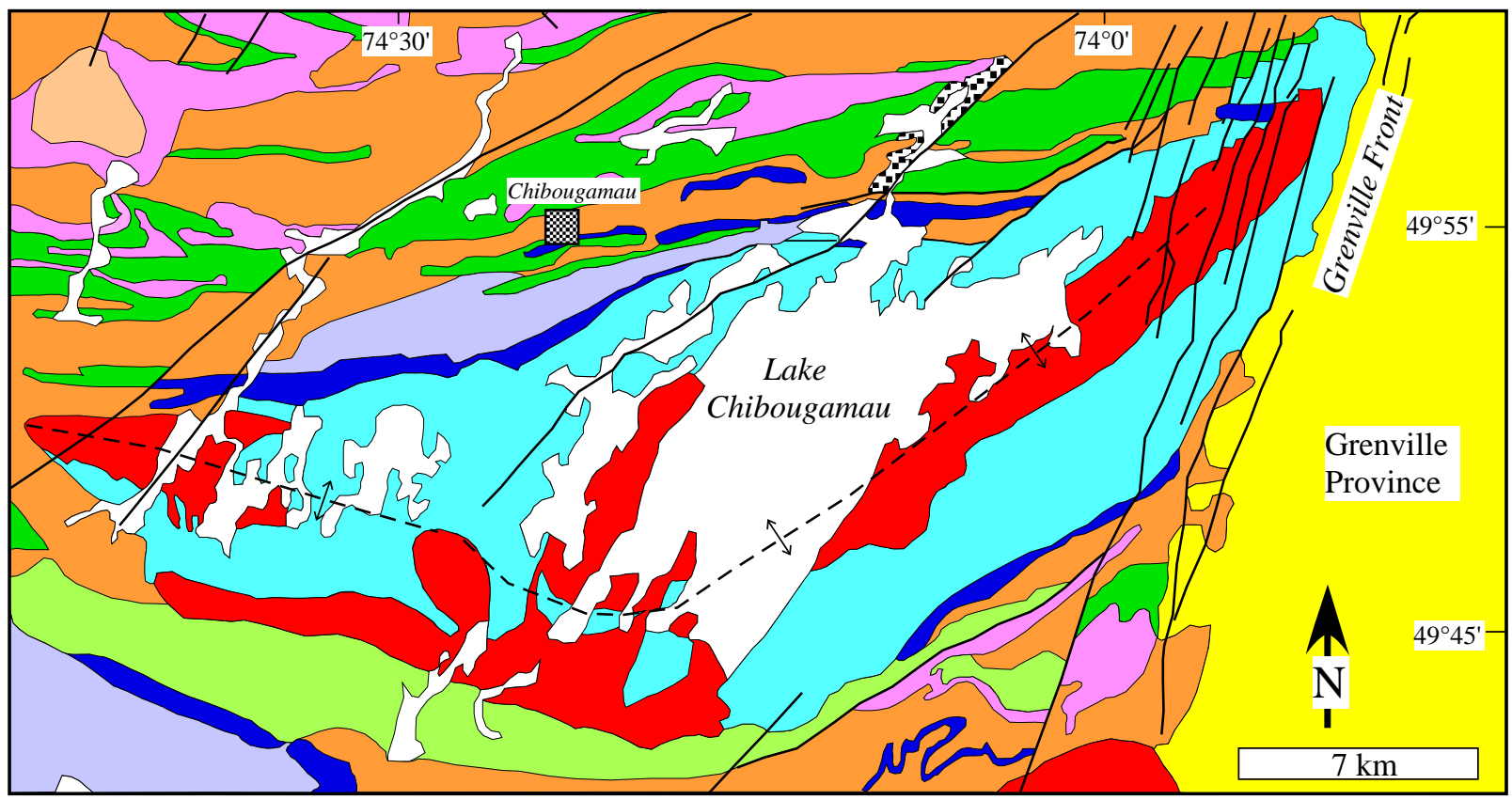

Legend

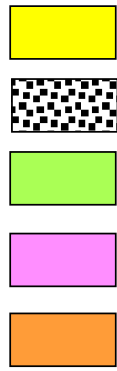

Grenville Province

Chibougamau Formation

Opémisca Group

Blondeau and Borldeleau Formations

Gilman Formation
Waconichi Formation

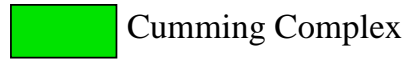

Obatogamau Formation

Doré Lake Complex

Syn- to post-tectonic plutons

Synvolcanic plutons

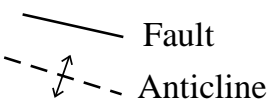


Fig. 3

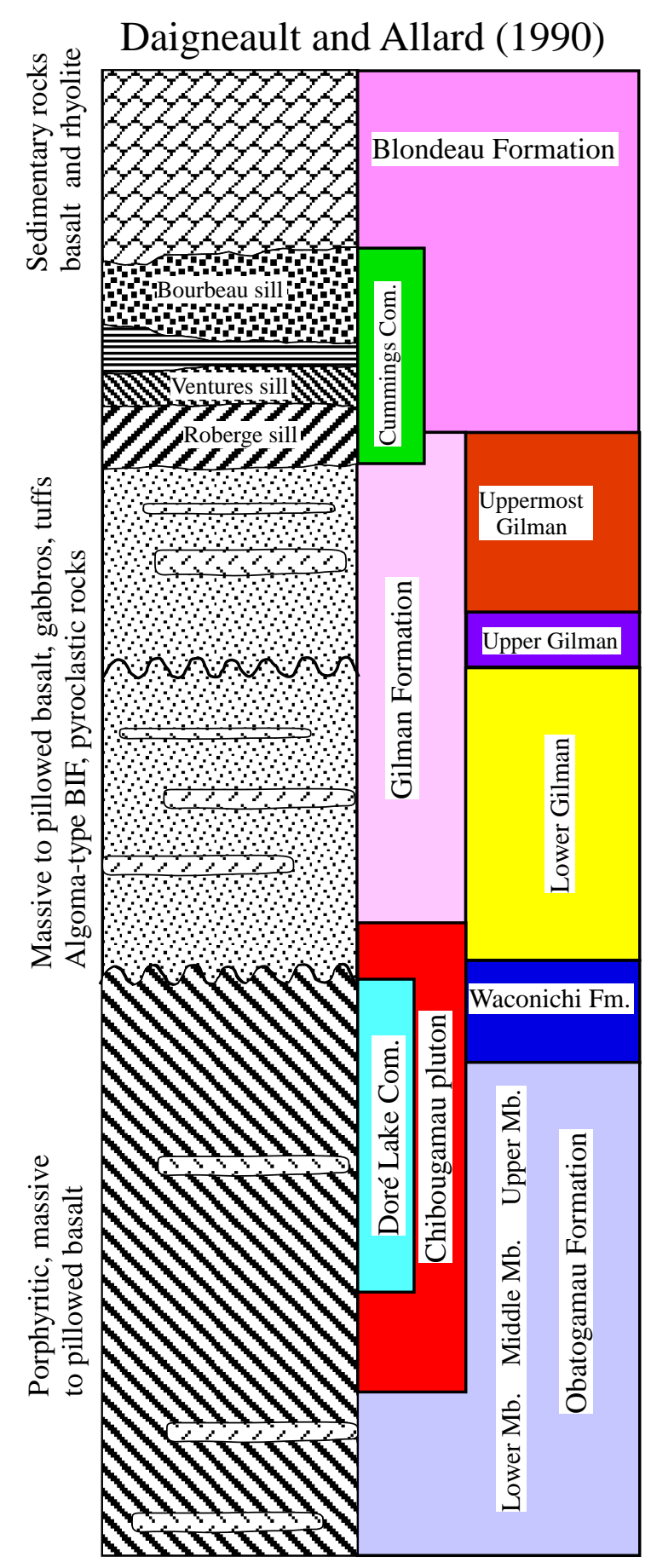

Leclerc et al. (2011)

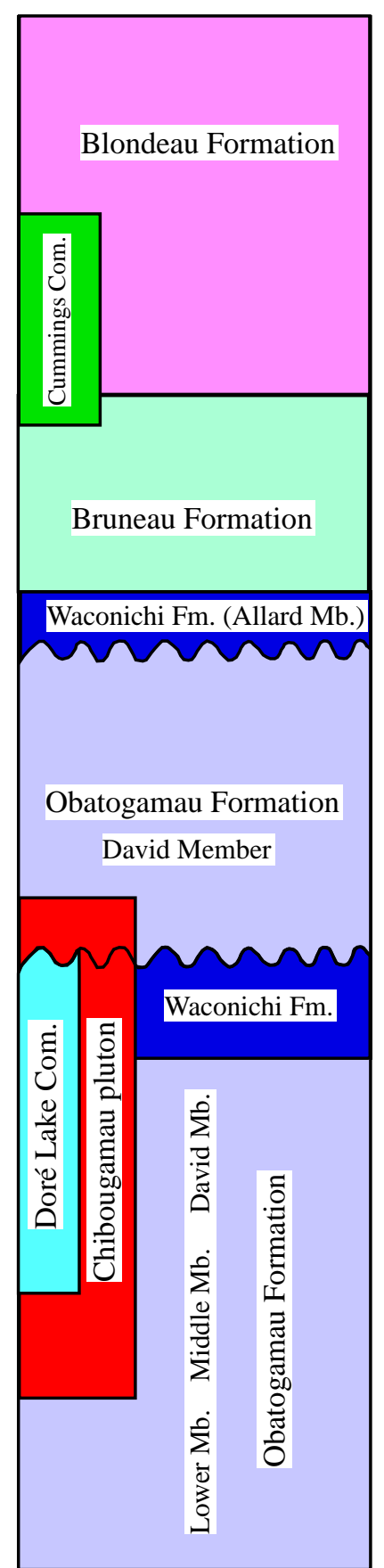


Fig. 4
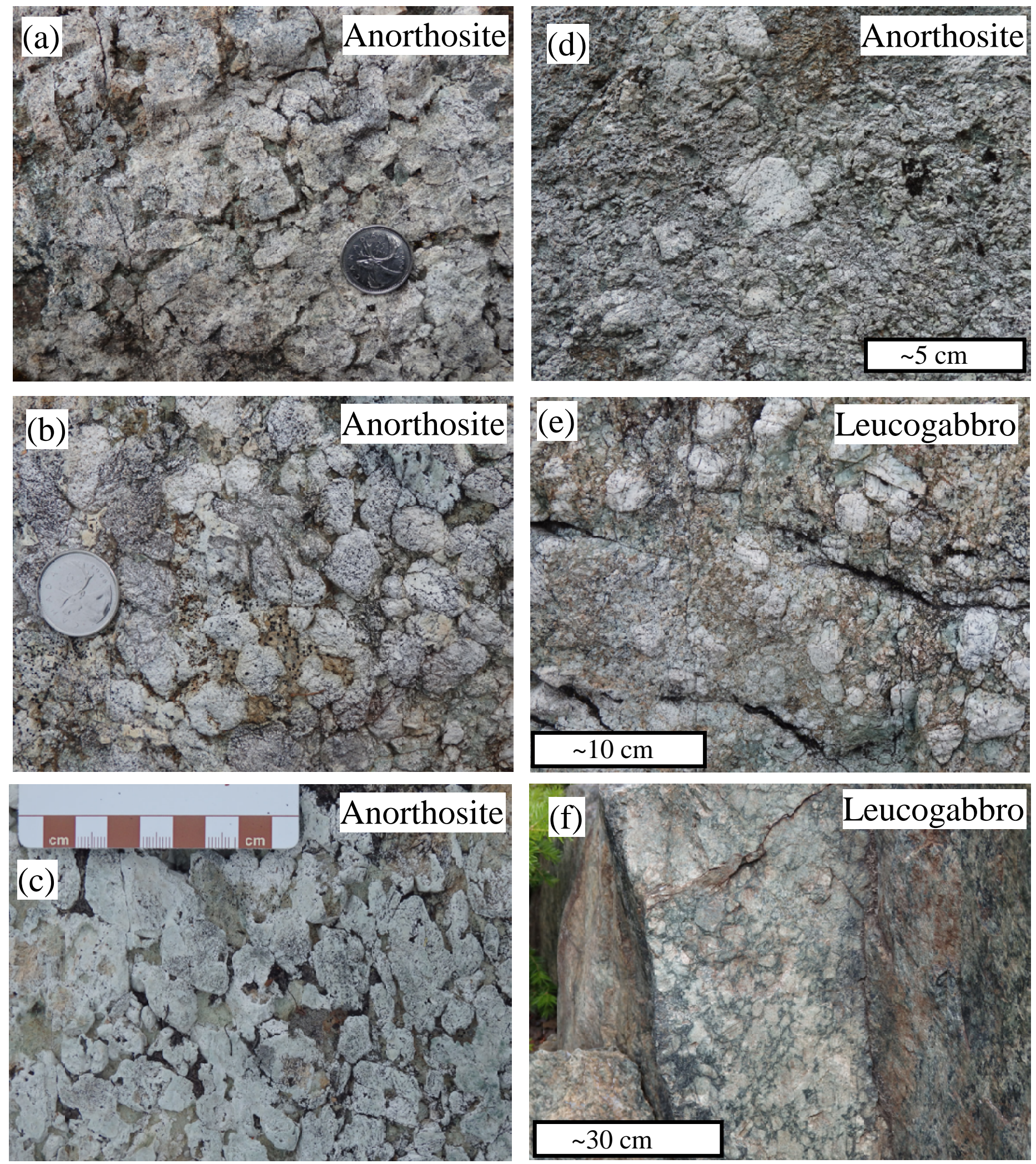
Fig. 5
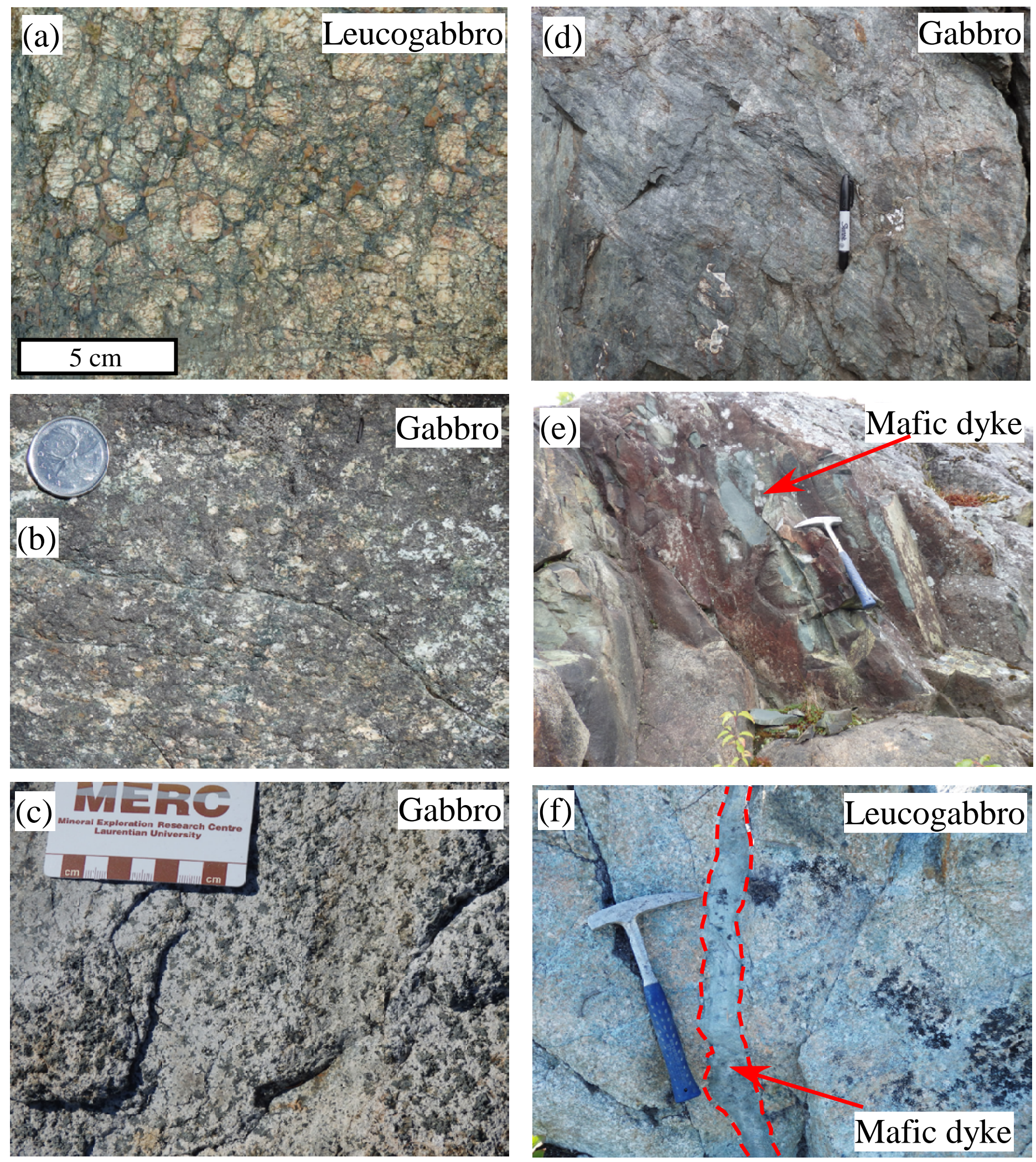
Fig. 6
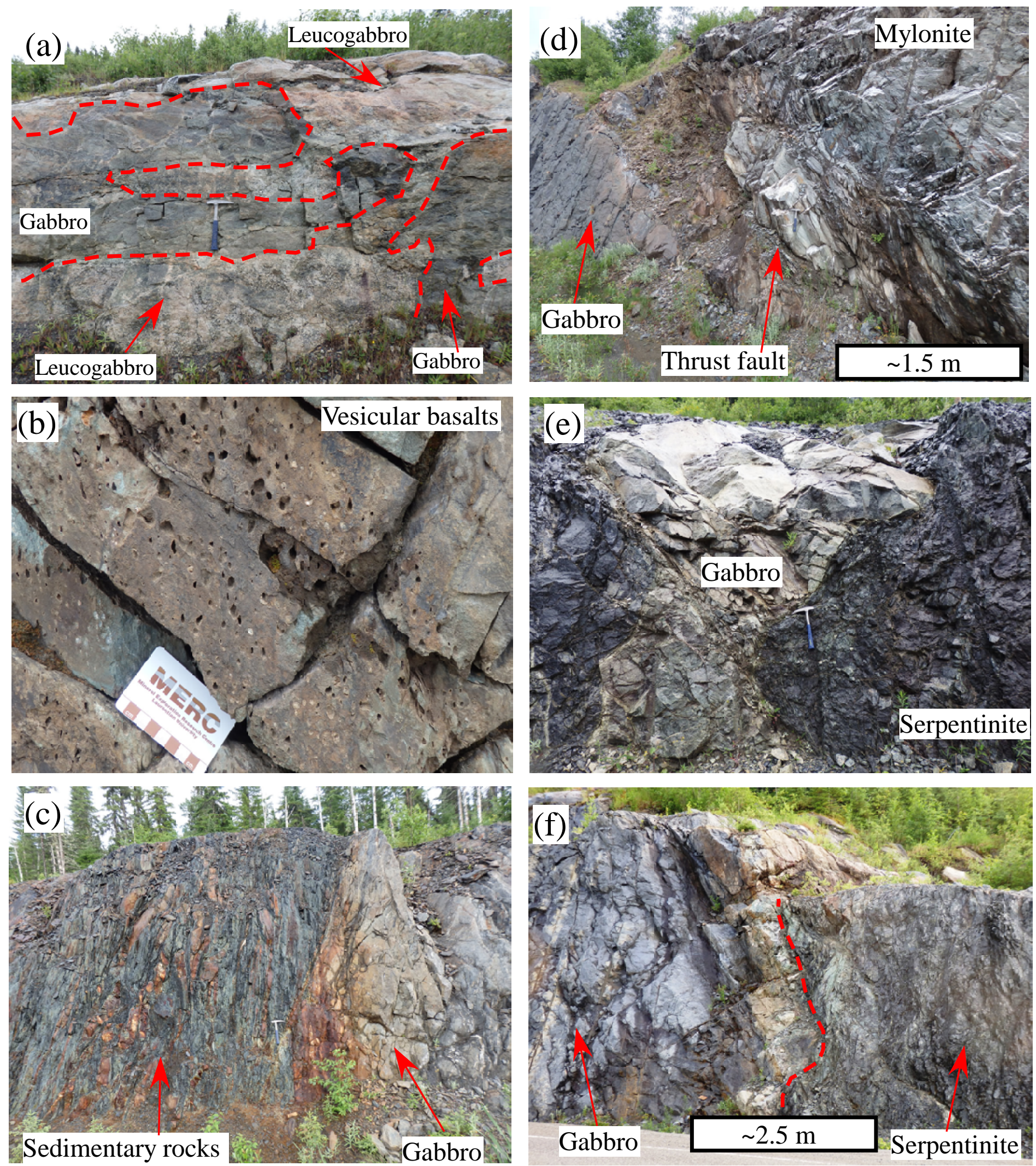
Fig. 7
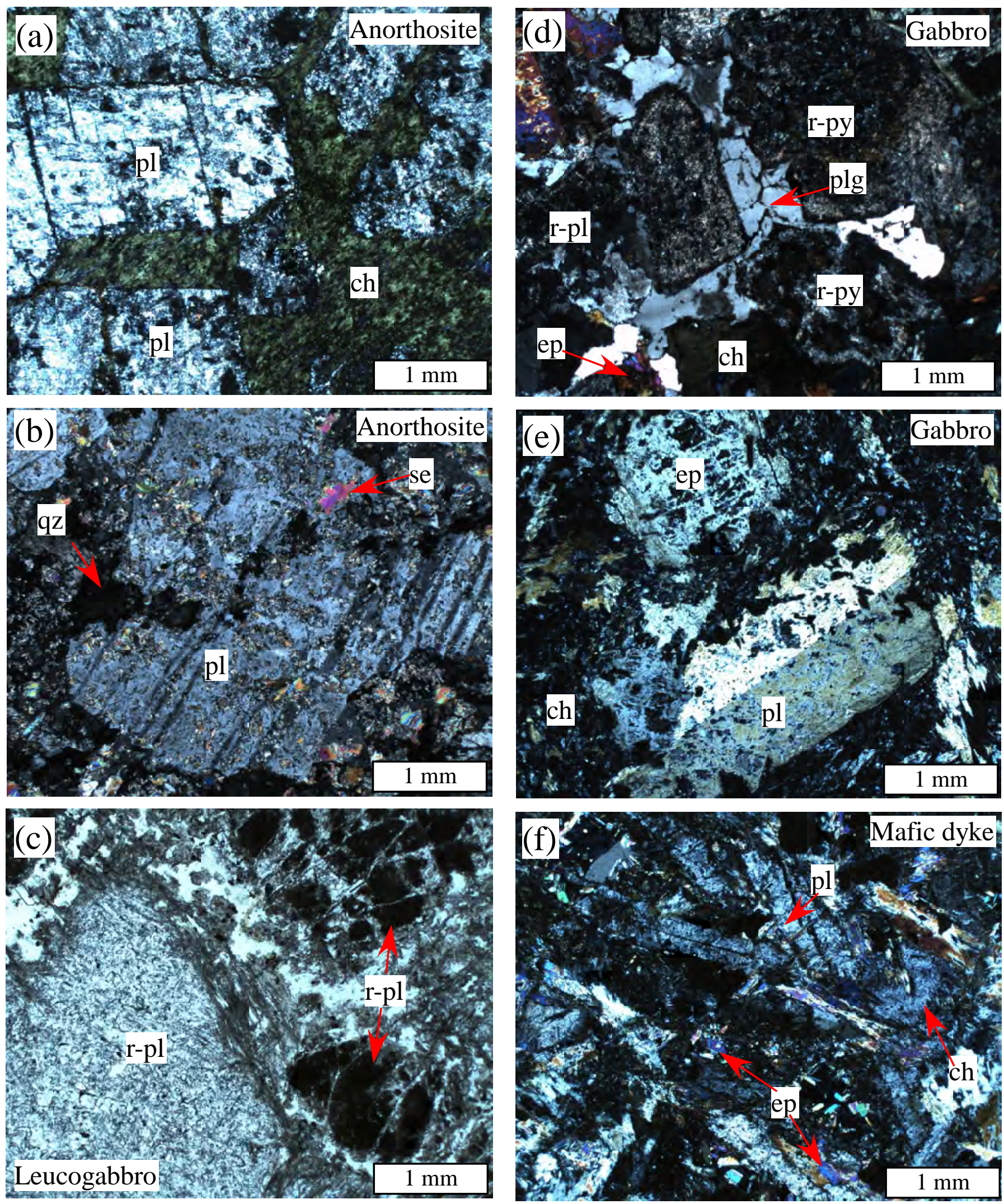
Fig. 8
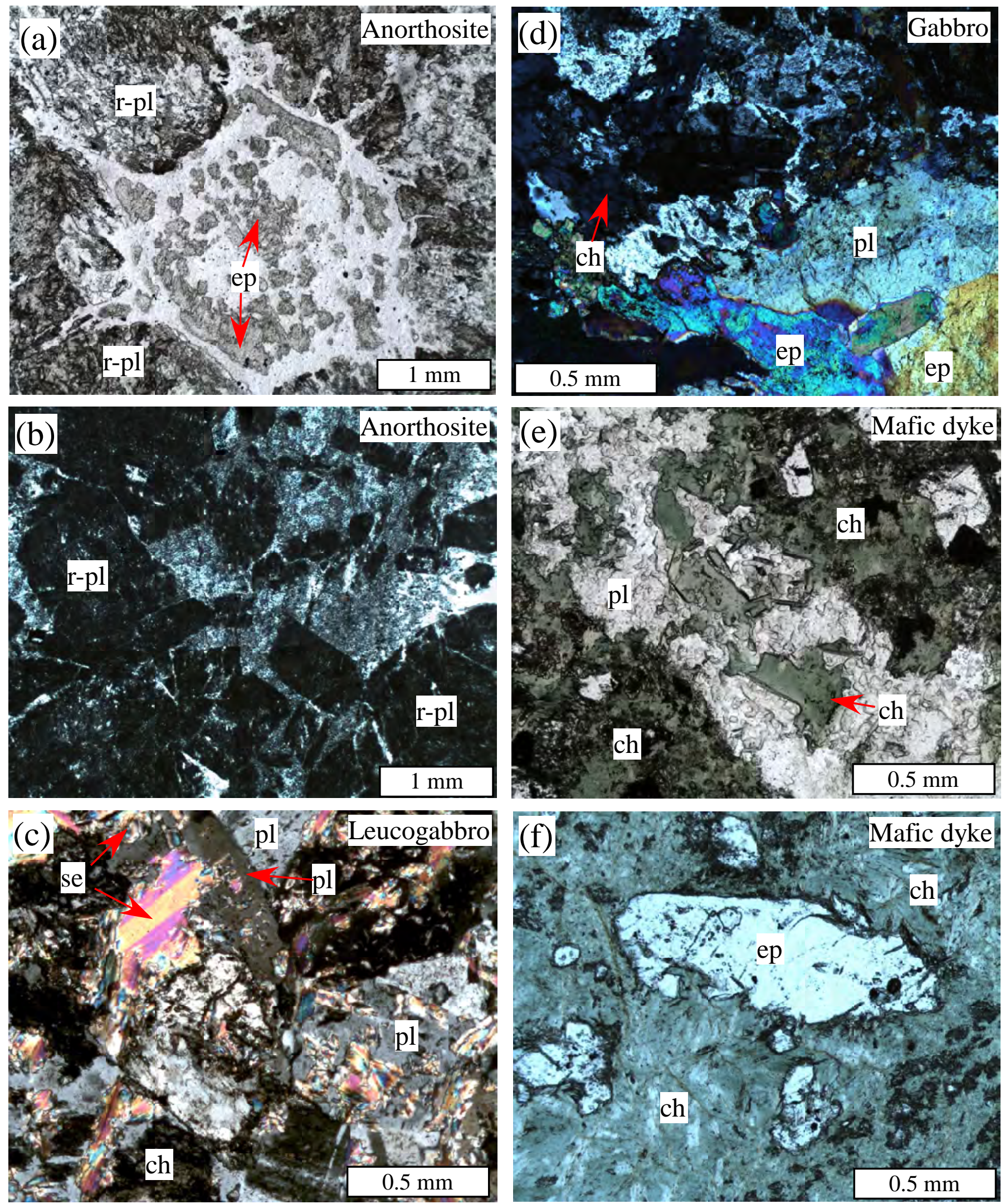
Fig. 9
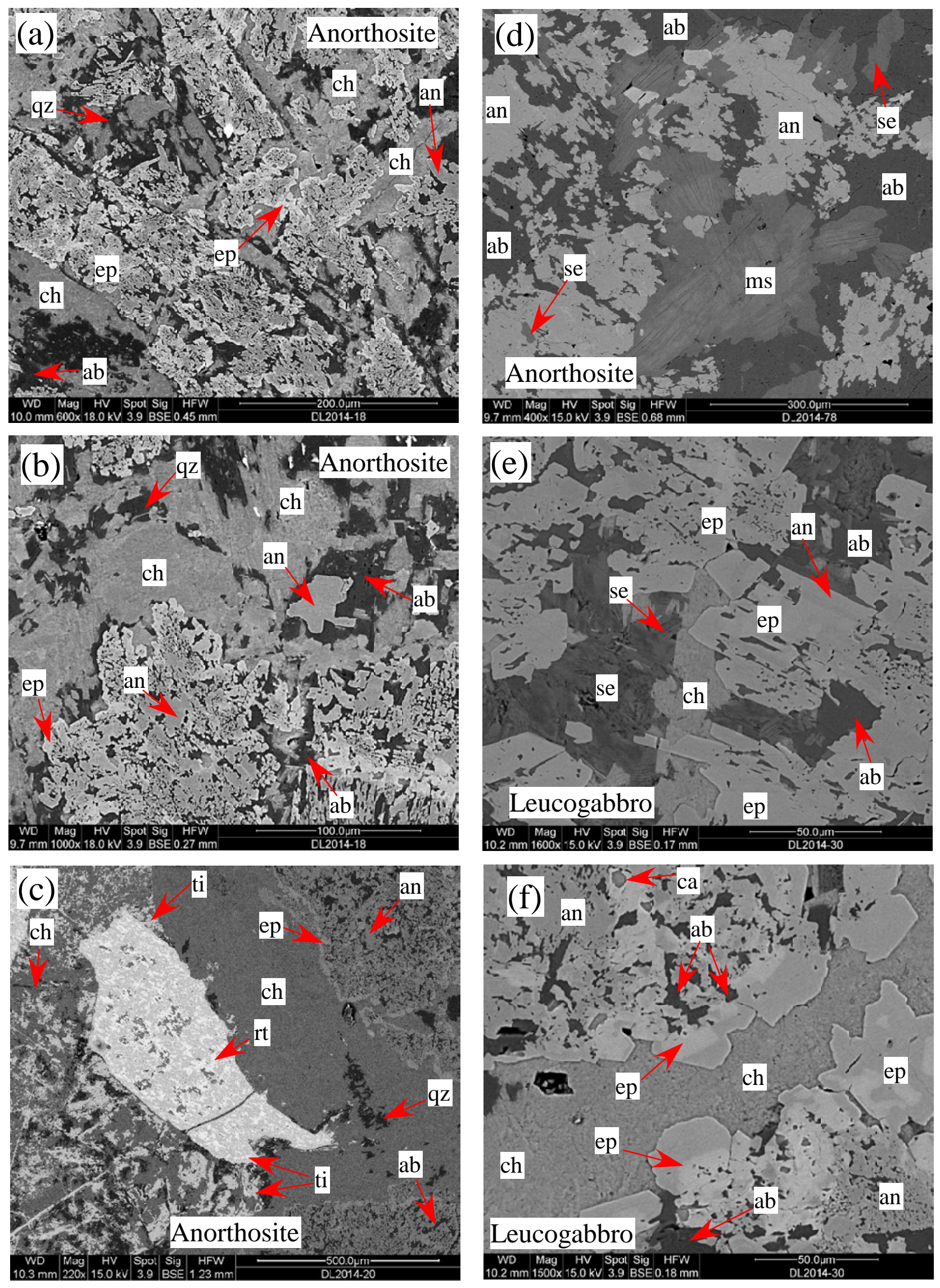
Fig. 10
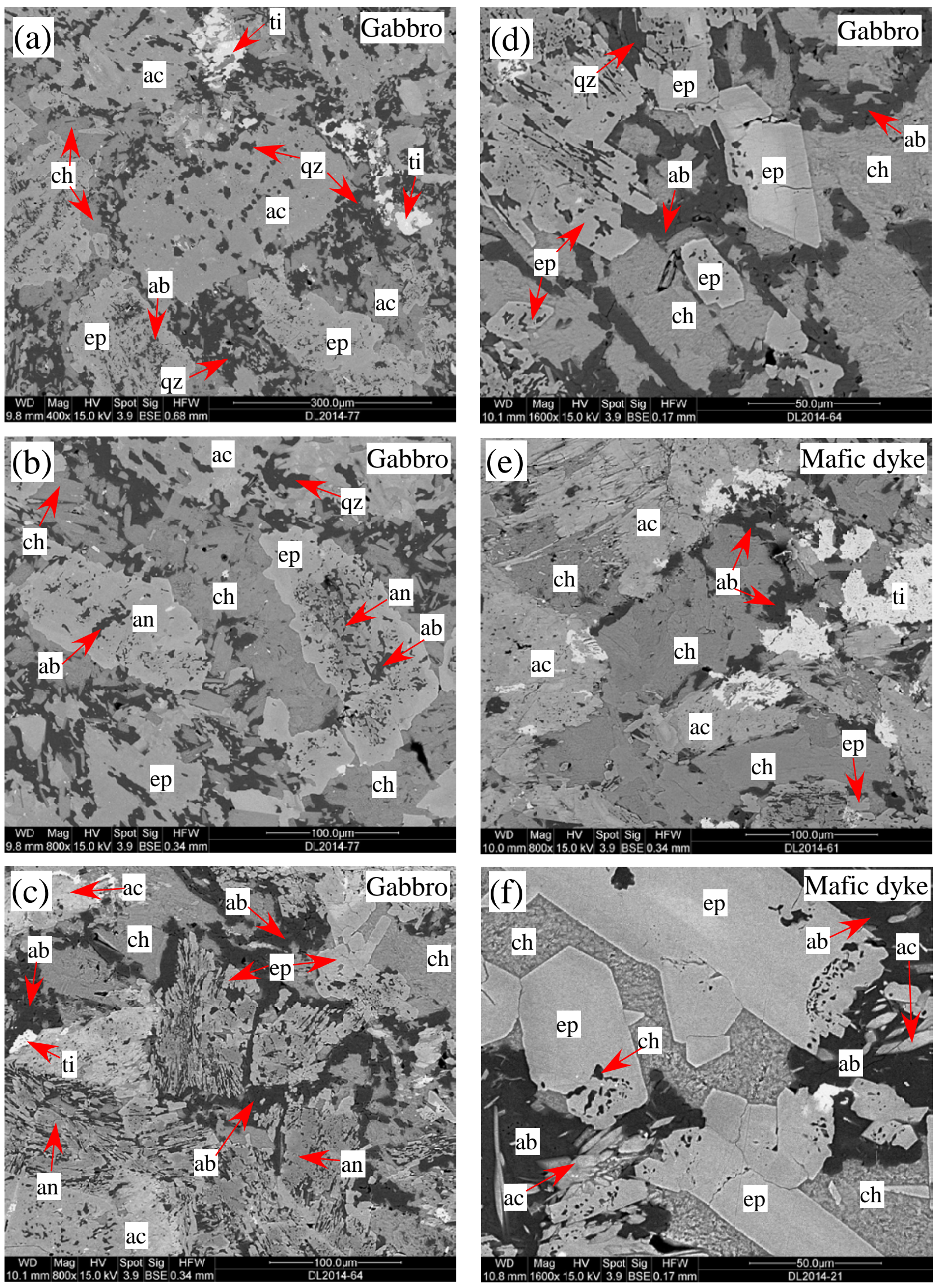
Fig. 11
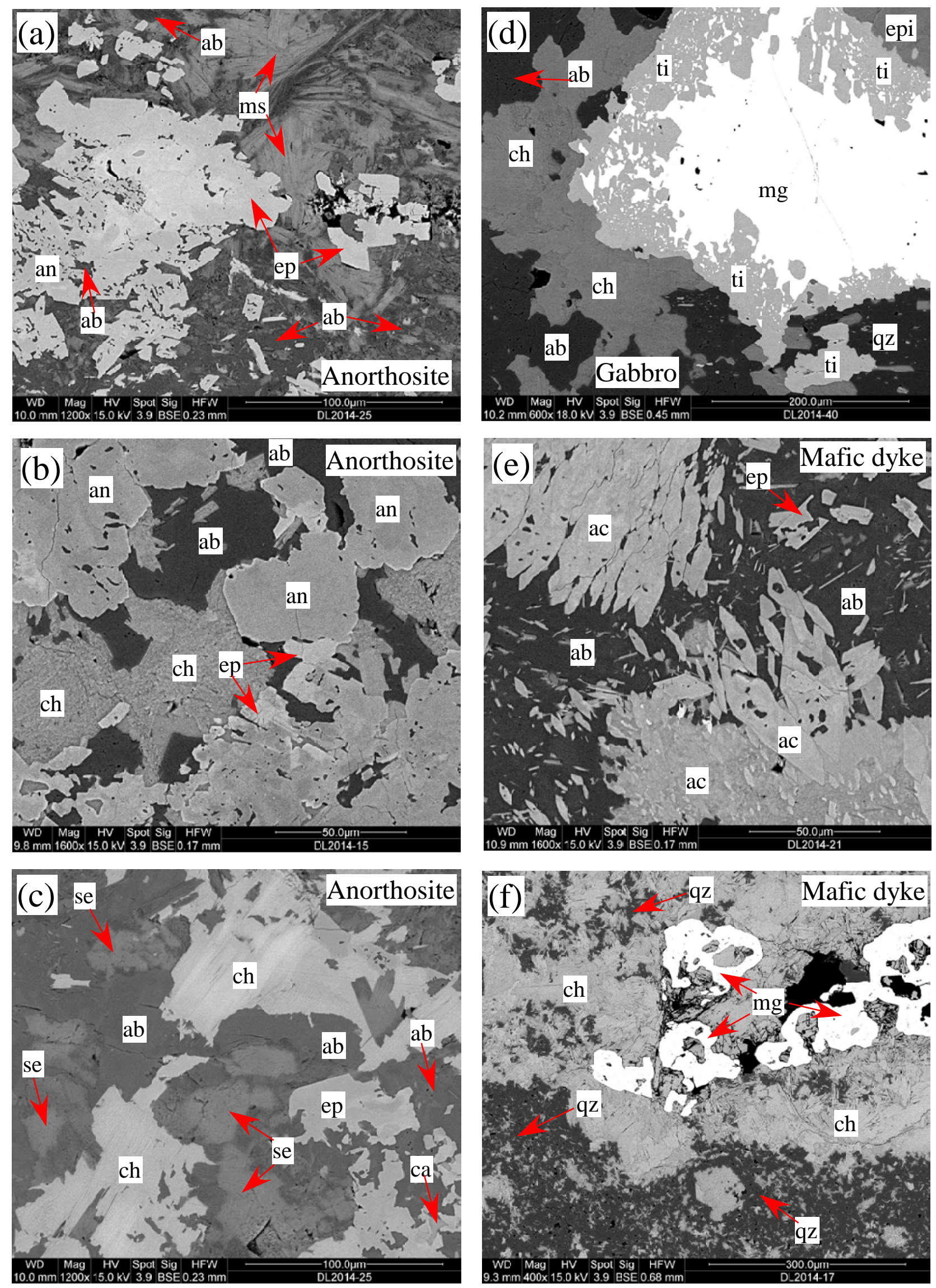
Fig. 12
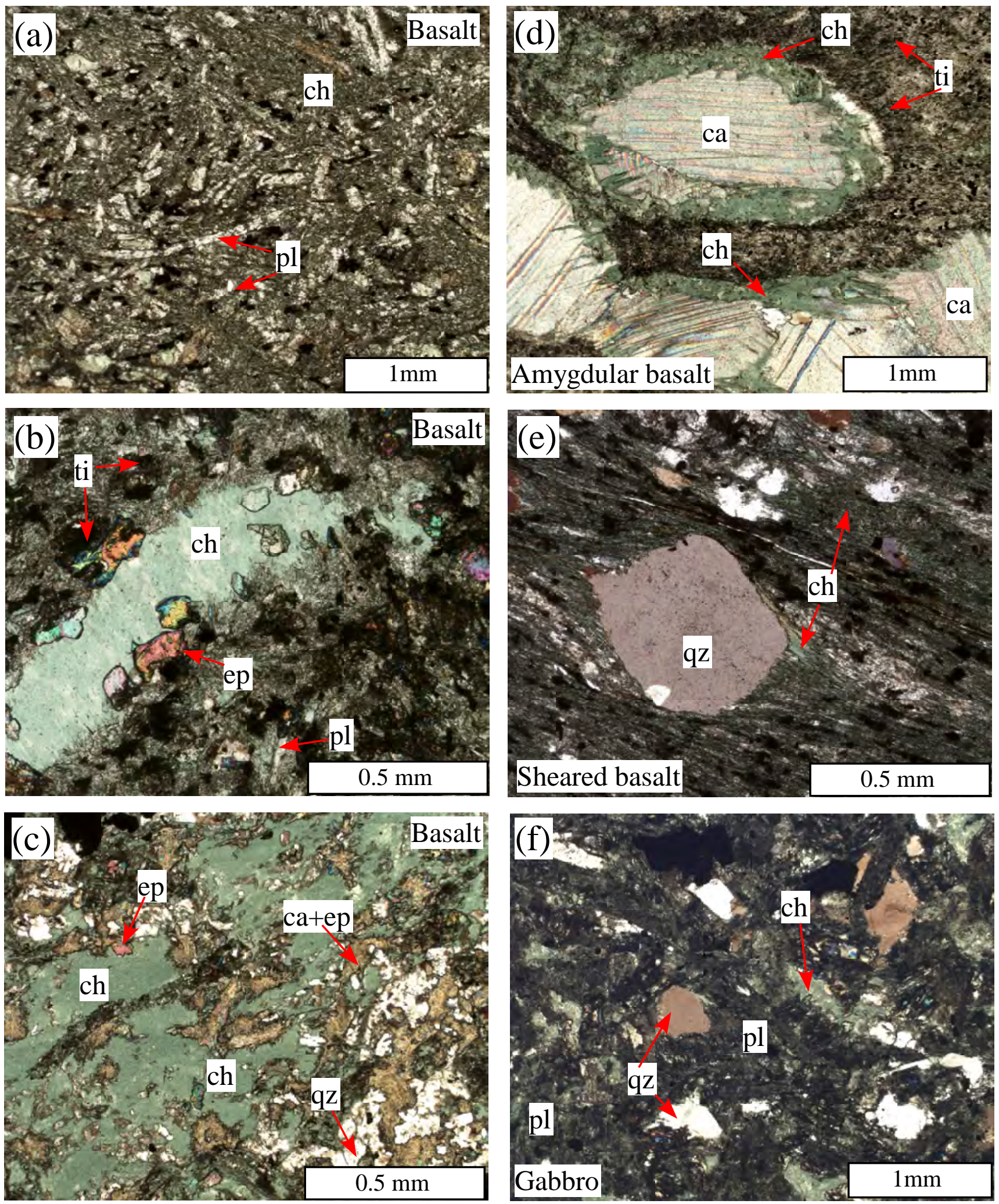
Fig. 13
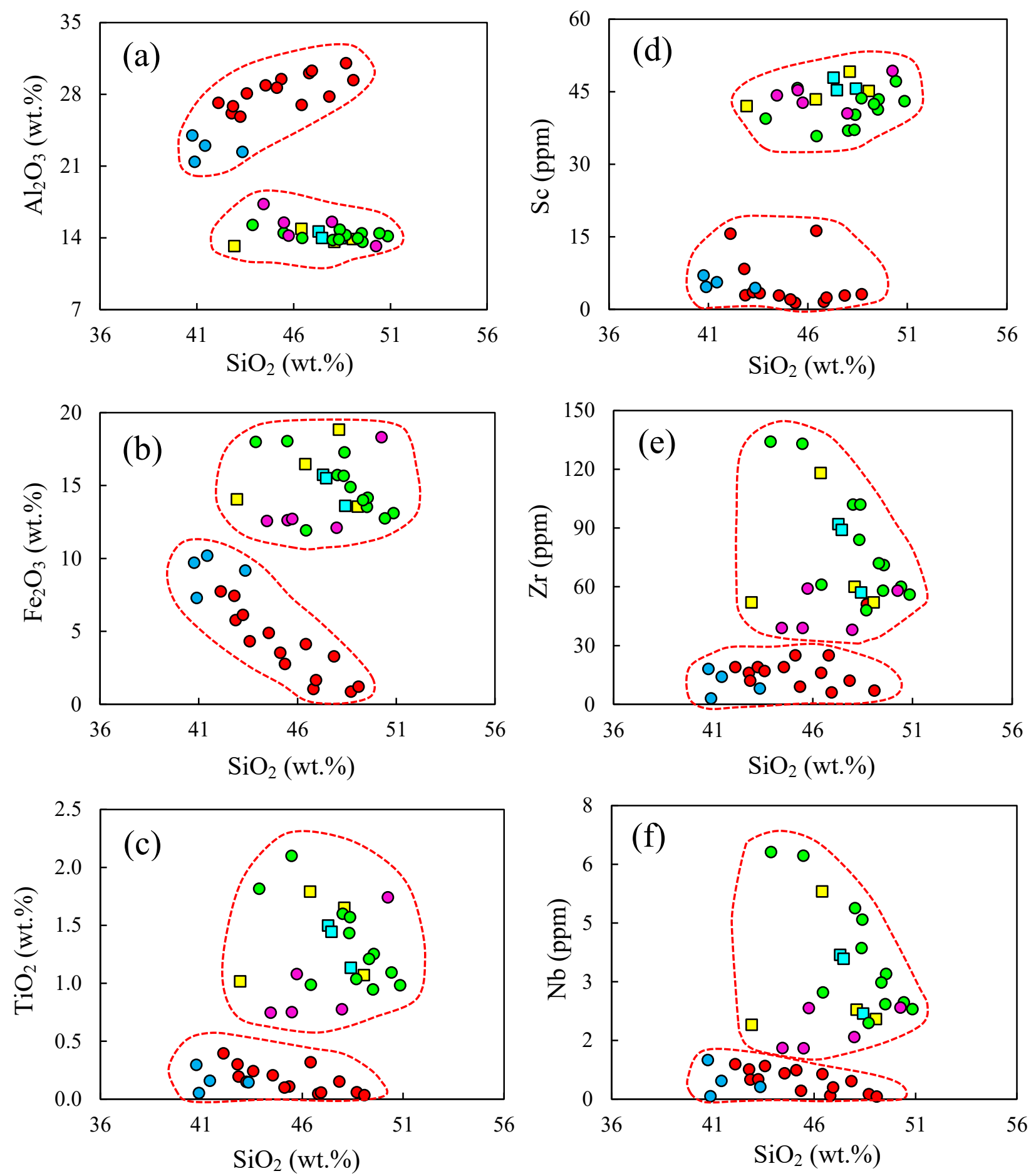
Anorthosite (DLC)
$\square$ Gabbro (DLC)
O Basalt (Obatogamau Formation)
$\bigcirc$ Leucogabbro (DLC)
$\square$ Mafic dyke (DLC)
Gabbro (Obatogamau Formation) 
Fig. 14
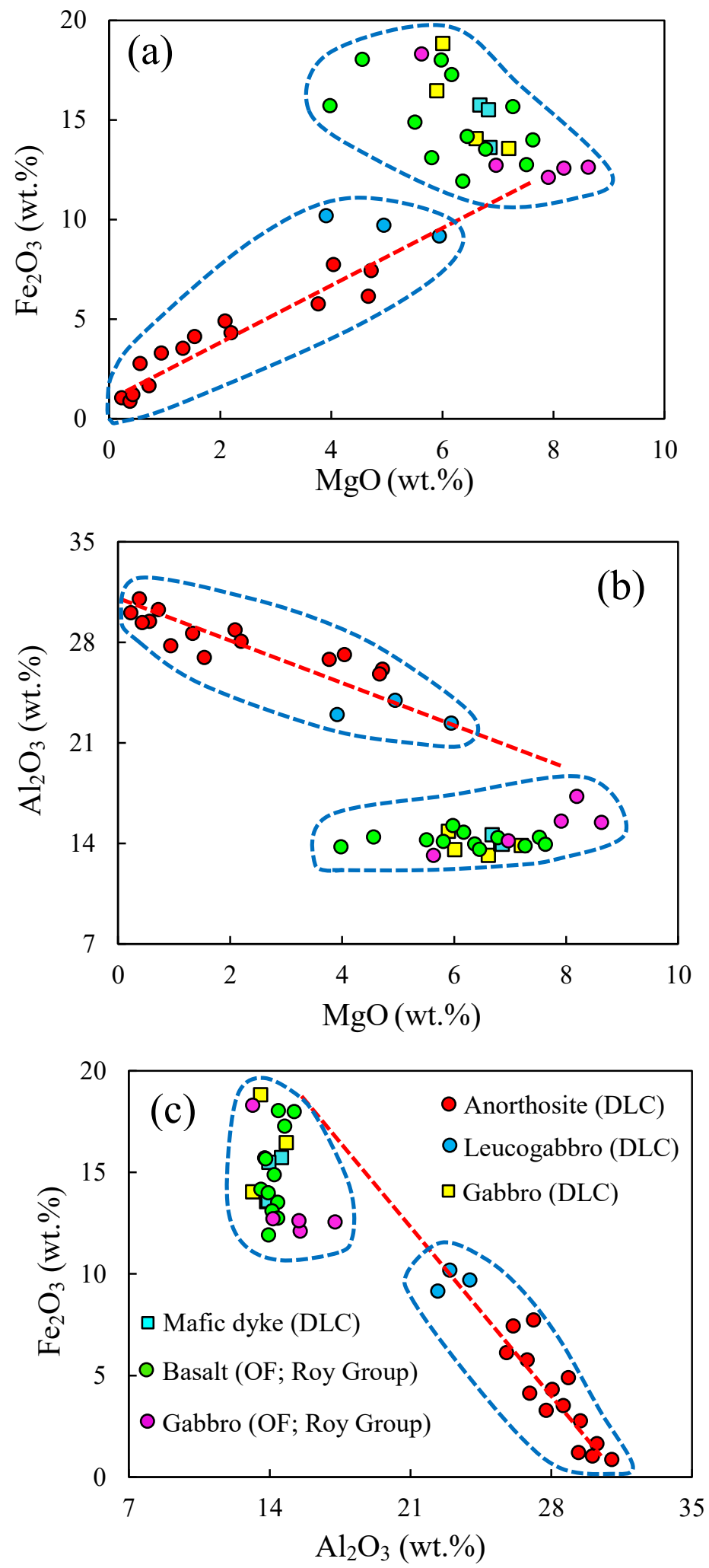
Fig. 15

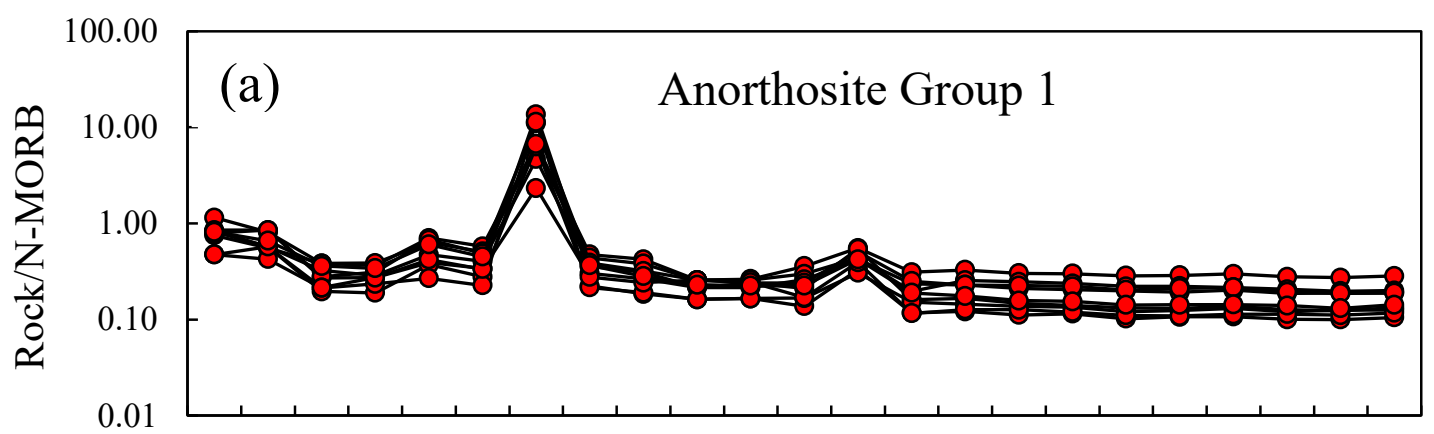

Th U Nb Ta La Ce Pb Pr Nd Zr Hf Sm Eu Ti Gd Tb Dy Y Ho Er Tm Yb Lu

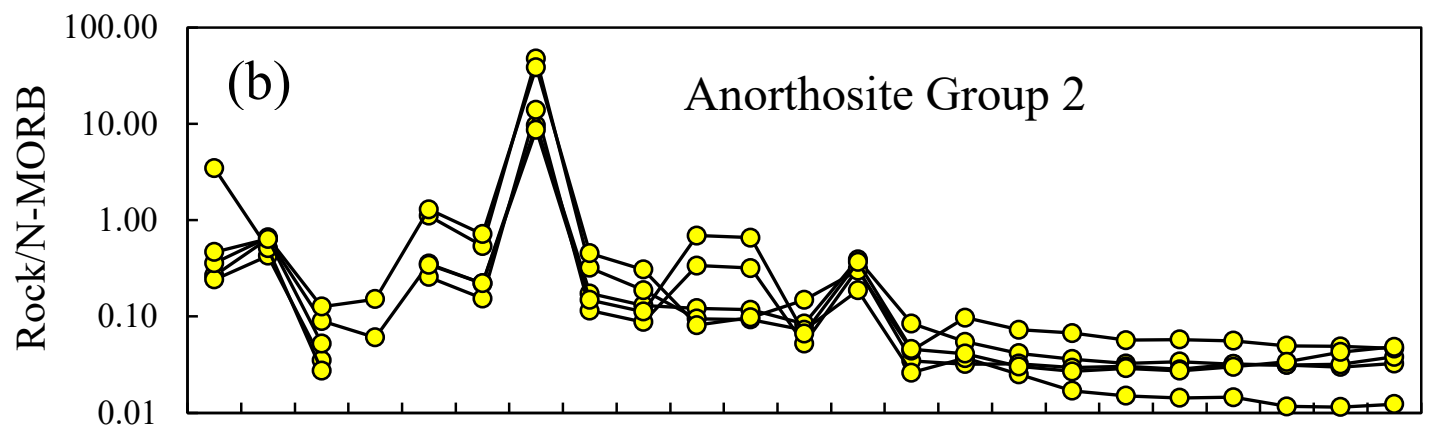

Th $\mathrm{U}$ Nb Ta $\mathrm{La} \mathrm{Ce} \mathrm{Pb} \mathrm{Pr} \mathrm{Nd} \mathrm{Zr} \mathrm{Hf} \mathrm{Sm} \mathrm{Eu} \mathrm{Ti} \mathrm{Gd} \mathrm{Tb} \mathrm{Dy} \mathrm{Y} \mathrm{Ho} \mathrm{Er} \mathrm{Tm} \mathrm{Yb} \mathrm{Lu}$

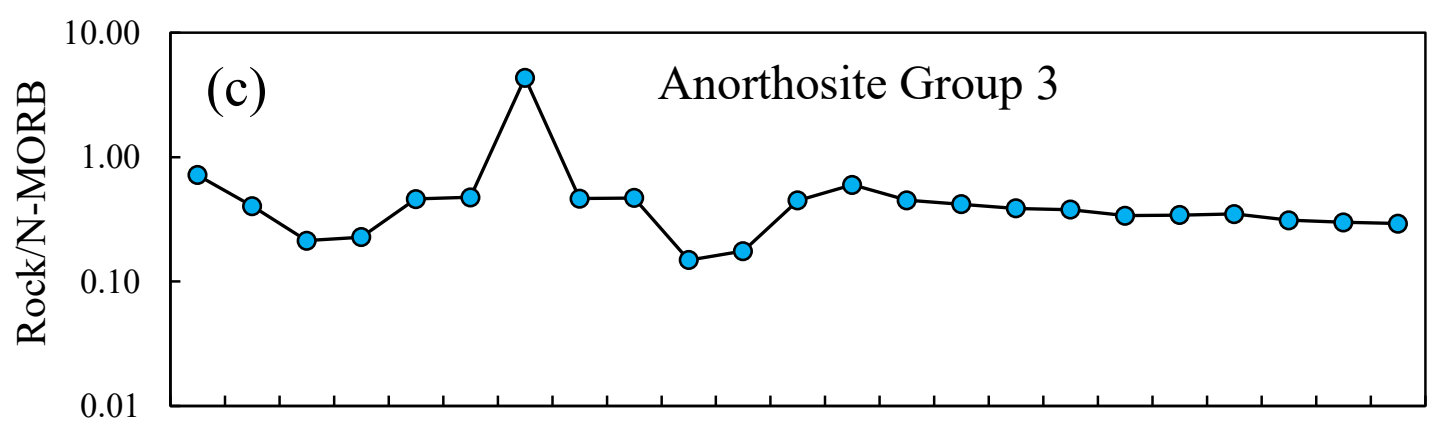

Th $\mathrm{U}$ Nb Ta $\mathrm{La} \mathrm{Ce} \mathrm{Pb}$ Pr Nd Zr Hf Sm Eu Ti Gd Tb Dy Y Ho Er Tm Yb Lu

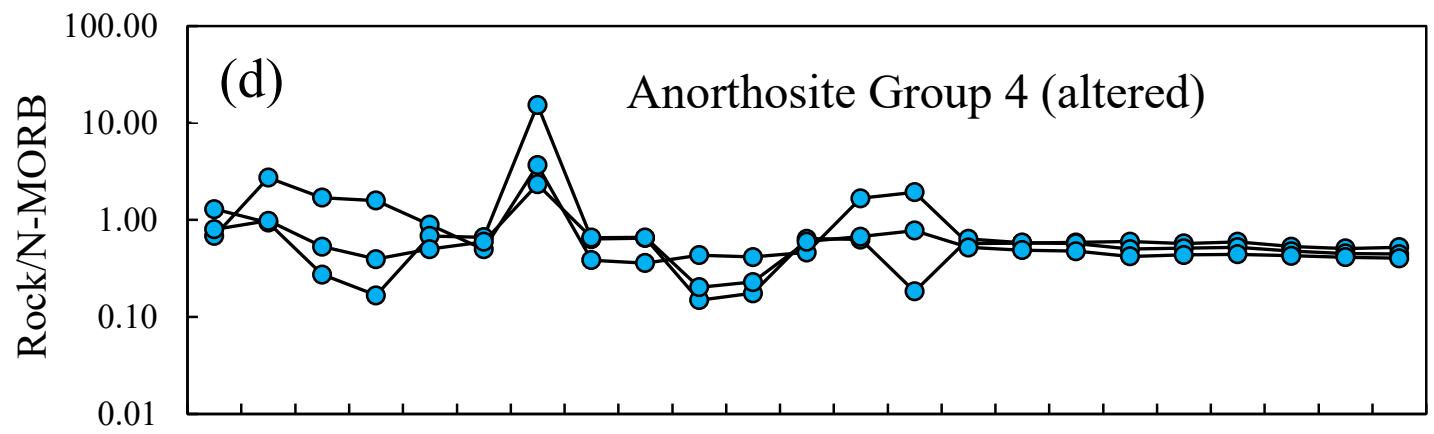

Th U Nb Ta La Ce Pb Pr Nd Zr Hf Sm Eu Ti Gd Tb Dy Y Ho Er Tm Yb Lu 
Fig. 16

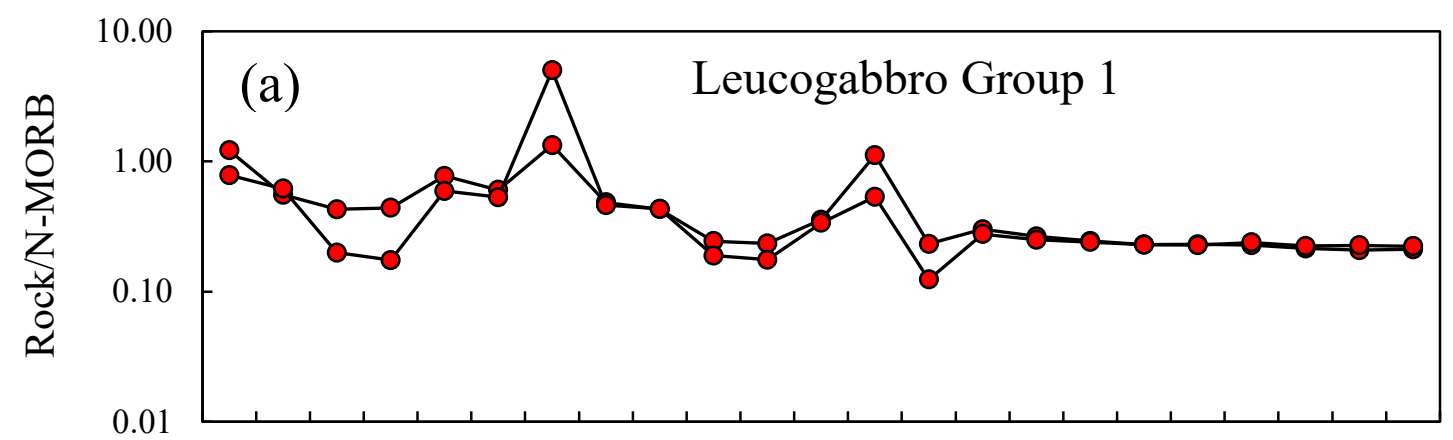

Th U Nb Ta La Ce Pb Pr Nd Zr Hf Sm Eu Ti Gd Tb Dy Y Ho Er Tm Yb Lu

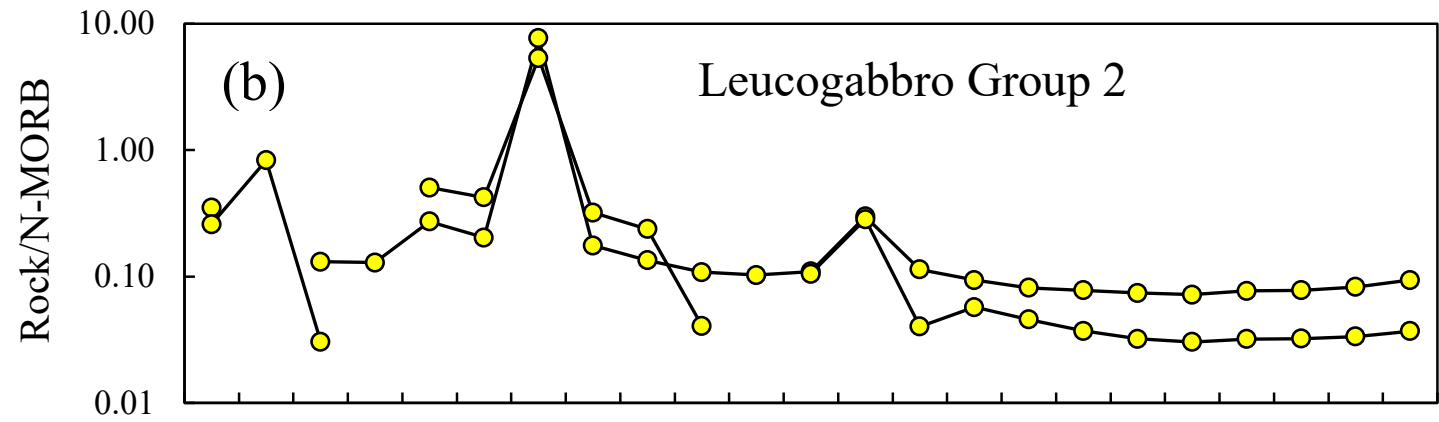

Th U Nb Ta La Ce Pb Pr Nd Zr Hf Sm Eu Ti Gd Tb Dy Y Ho Er Tm Yb Lu

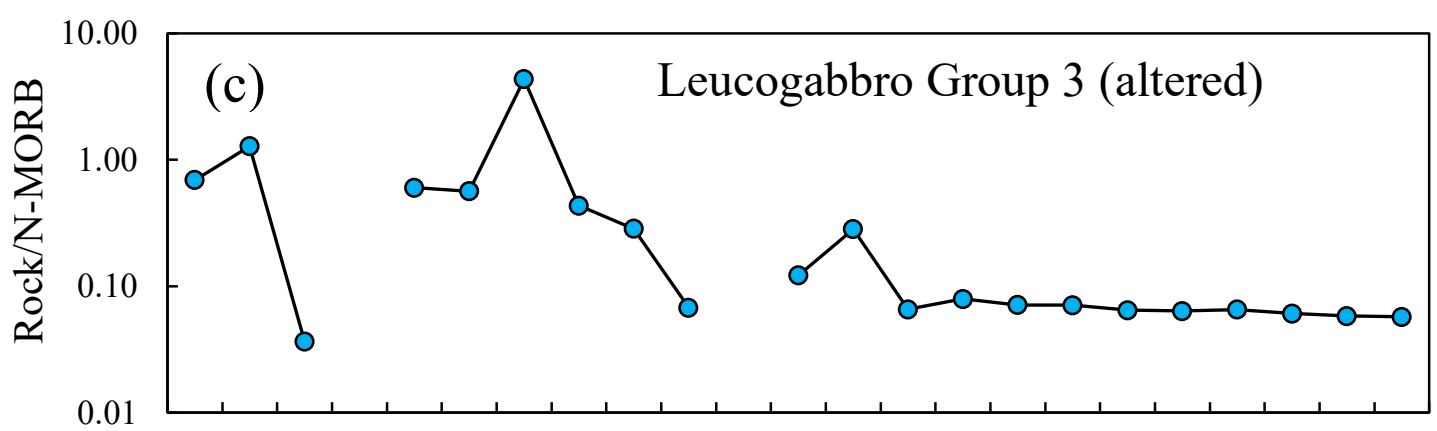

Th $\mathrm{U}$ Nb Ta La Ce Pb Pr Nd Zr Hf Sm Eu Ti Gd Tb Dy Y Ho Er Tm Yb Lu

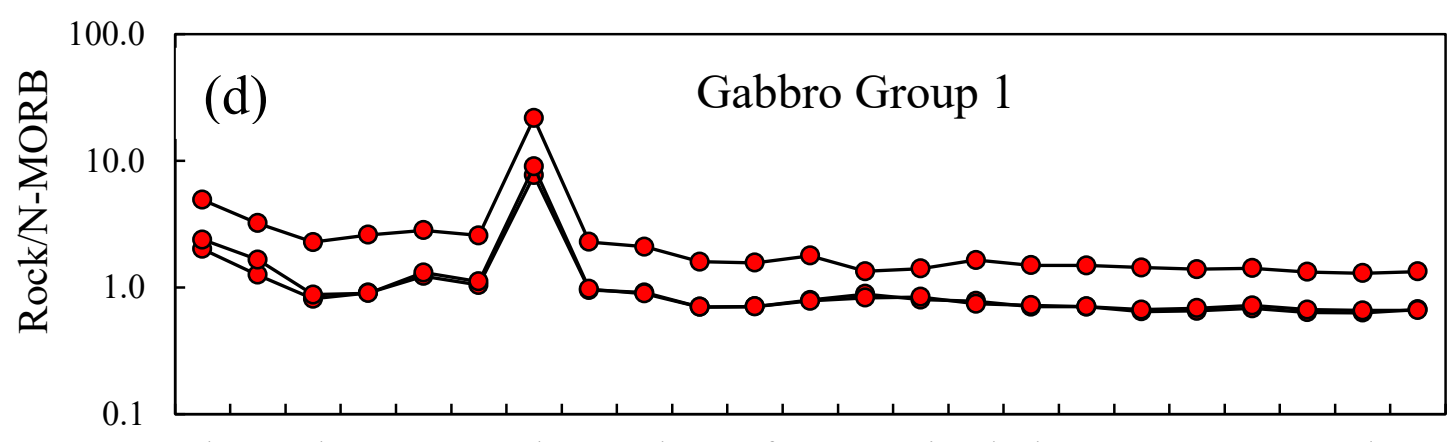

Th $\mathrm{U}$ Nb Ta La Ce Pb Pr Nd Zr Hf Sm Eu Ti Gd Tb Dy Y Ho Er Tm Yb Lu 
Fig. 17

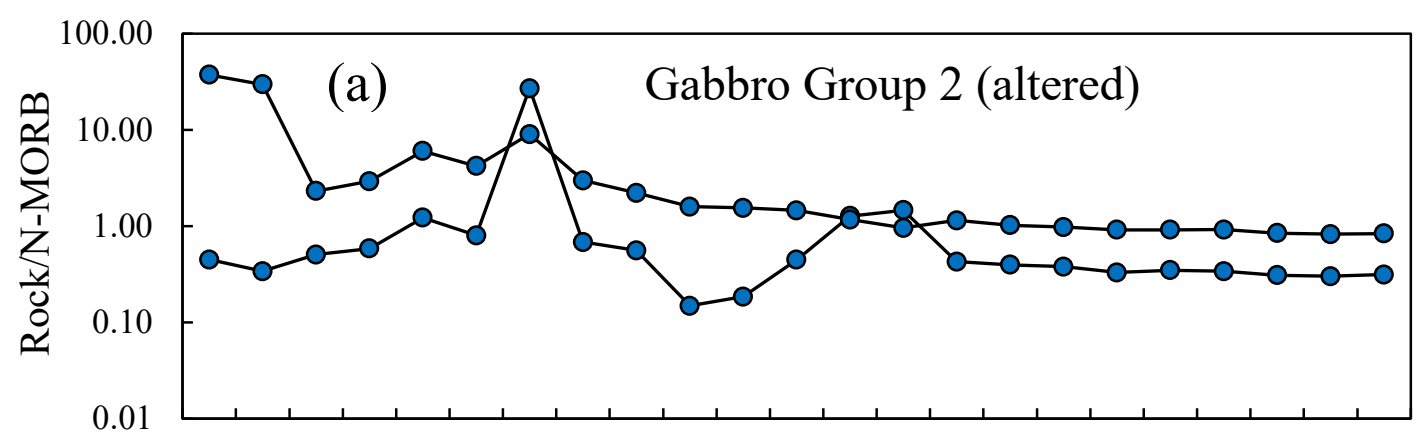

Th $\mathrm{U}$ Nb Ta La Ce Pb Pr Nd Zr Hf Sm Eu Ti Gd Tb Dy Y Ho Er Tm Yb Lu

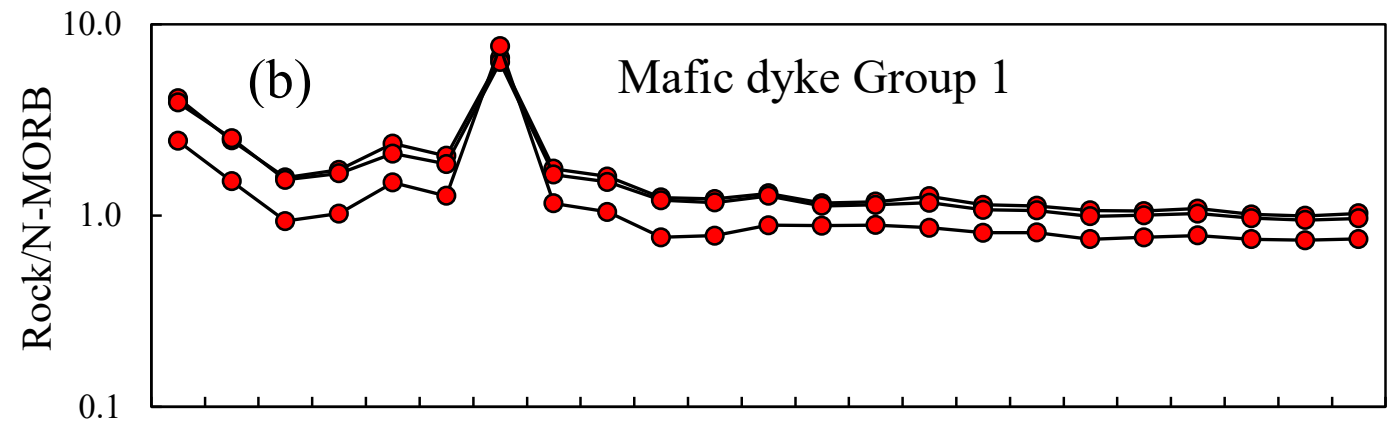

Th $\mathrm{U}$ Nb Ta La Ce Pb Pr Nd Zr Hf Sm Eu Ti Gd Tb Dy Y Ho Er Tm Yb Lu

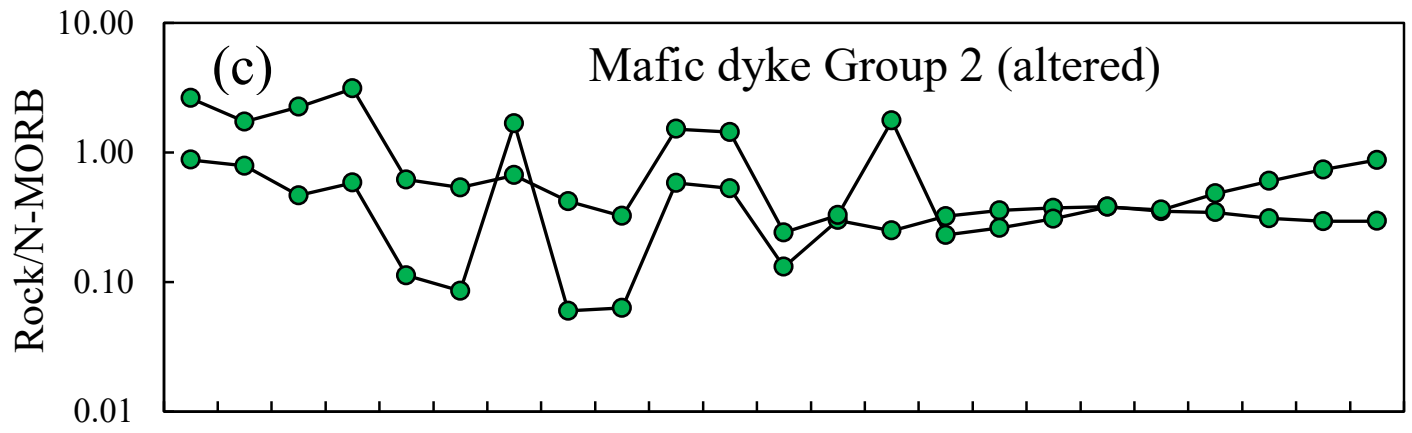

Th $\mathrm{U}$ Nb Ta $\mathrm{La} \mathrm{Ce} \mathrm{Pb}$ Pr Nd Zr Hf Sm Eu Ti Gd Tb Dy Y Ho Er Tm Yb Lu 
Fig. 18
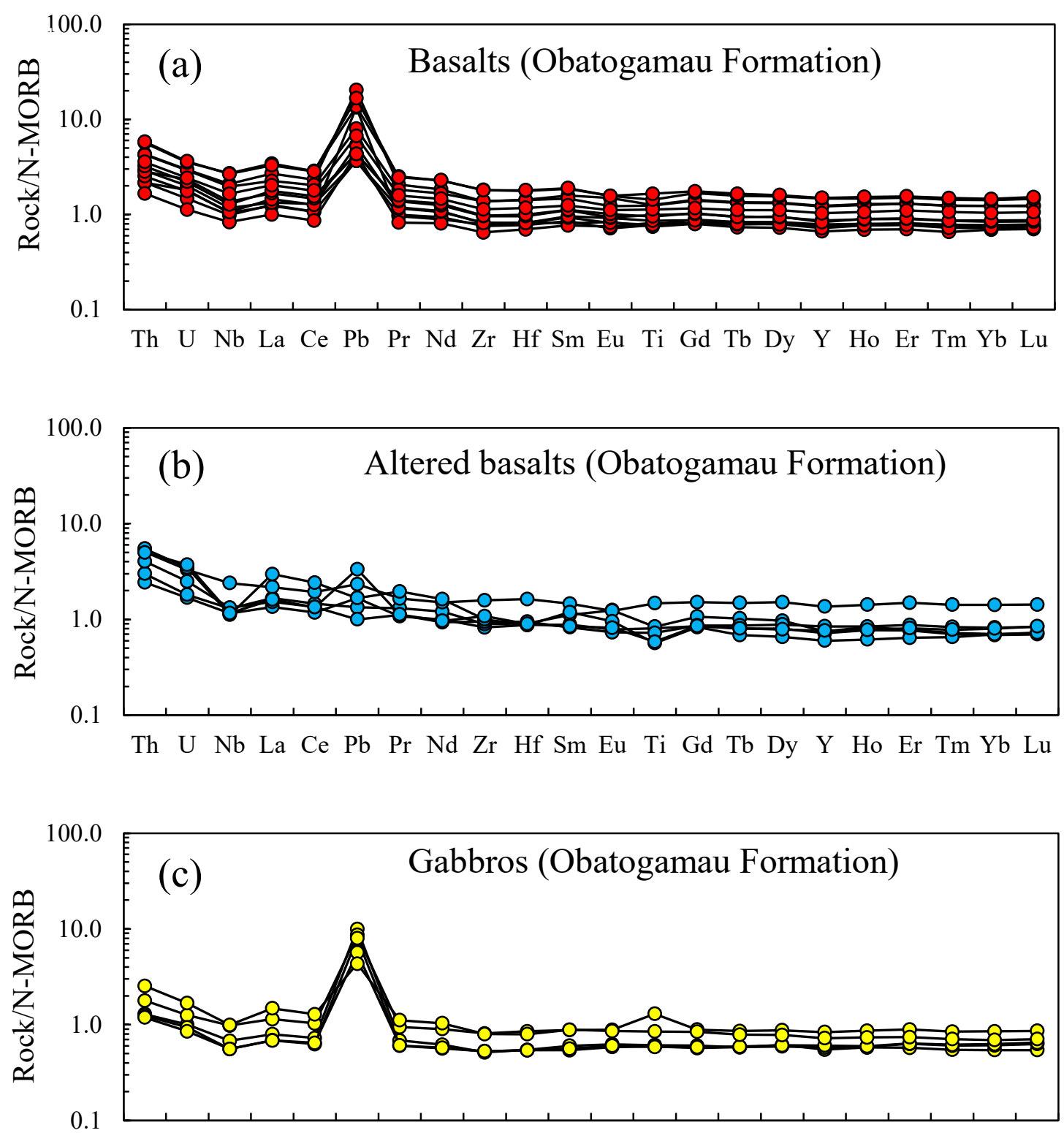

Th U Nb La Ce Pb Pr Nd Zr Hf Sm Eu Ti Gd Tb Dy Y Ho Er Tm Yb Lu 
Fig. 19
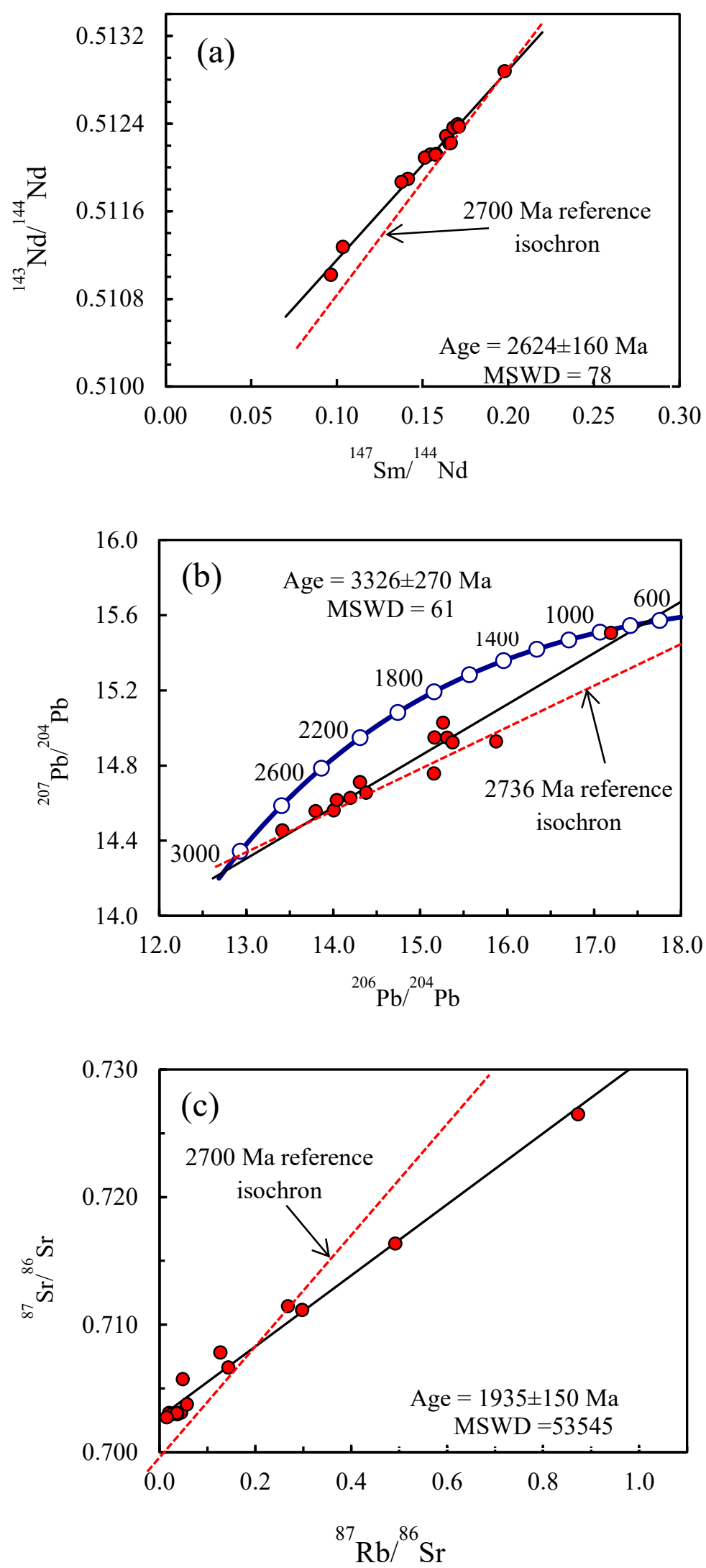
Fig. 20
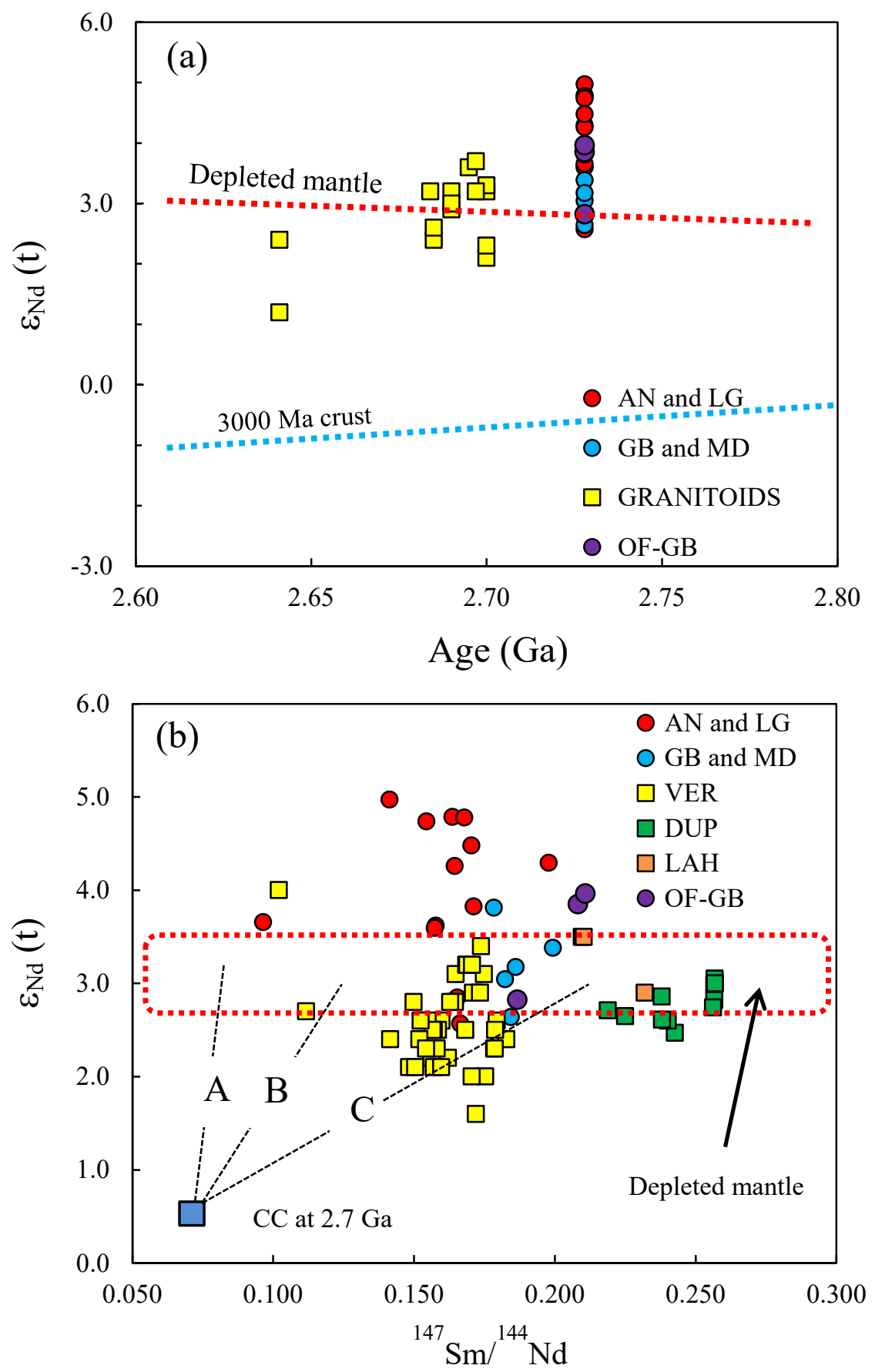